\title{
SEISMIC RESPONSE OF STEEL BEAMS COUPLING CONCRETE WALLS
}

\author{
by \\ KENT A. HARRIES
}

May 1992

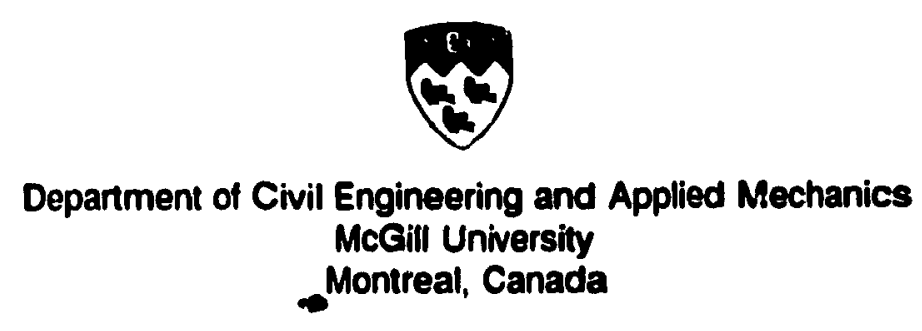

A thesis submitted to the Faculty of Graduate Studies and Research in partial fulfilment of the requirements for the degree of Master of Engineering

- Kent A. Harries, 1992 


\begin{abstract}
Abotract

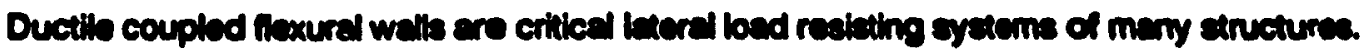

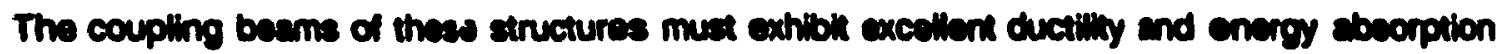
sbilly. To achieve better ductility and eneroy sbeorption then proviounly posebble, the ues of ated lint beams with their ends embedded in the reintorced concrete weils is proposed. Prellnineny experimented results are reported for two full-scale reversed cyclic loading teats of portions of ouctile flexurel walls coupled with steel link beams. The excellenk performance, together with the ease of construction, demonstrate the feasibility of this shernative form of constnuction. In order to ensure ductile response, design and detaling guidelines for both the clear spen and embedded pintions of the link beams and the reinforeed concrete cmbedment region are presented. An asesesmen, based on comparisons with other structural syetems, of this novel type of construction is preachted.
\end{abstract}




\section{Rcoums}

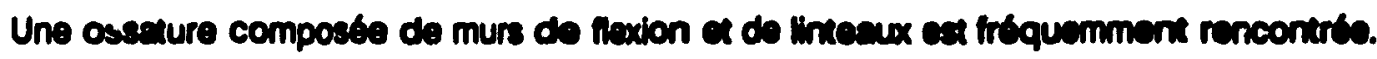
Les limeaux doivent demontrer une excellente ductilus et ebsorber besucoup d'énerg's. L'emploi do linteaux en scier de cherpente encestrts dens les murs de biton armb ext propost eif

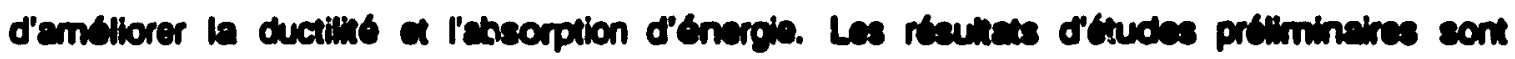
prbsentes pour deux specimens en de contreventemant crendeur rielve formbs do trumacux at de liriteaux en acier de chappente soumis a des charges cycliques renverabes. L'excellent comportement do ce systeme lors d'un sbisme at sa construction simple sasure lo succte de ce nouveau genre d'oseature ductile. Afin d'asaurer un compontement ductile, les proctidures de

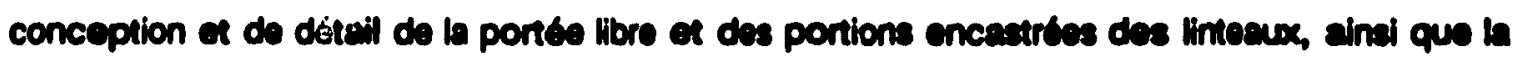
region d'encastrement des murs en beton arms, sont prtacnices Une comparicion enec

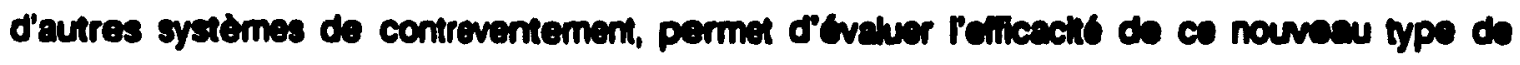
construction. 


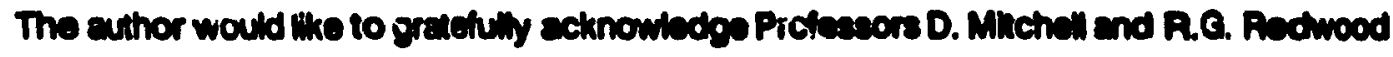
for their encouregement and guidence on this programmo. Furthermore, the suthor would illo to thank Dr. W.D. Cook for his encouragement and appont; Pon Sheppand and John Bantezek for their invelusble work in holping to prepare the spactmens and Jemis Mhenet, Andrew Criezic and Abent Wellrep for helping to teat the specimens.

The finencial suppon of the Naturd Sciences and Engineoring Reaearch Councll of Canada is gretefully seknowledged. 


\section{Table of Contente}

Abstract $\ldots \ldots \ldots \ldots \ldots \ldots \ldots \ldots \ldots \ldots \ldots \ldots \ldots \ldots \ldots \ldots \ldots \ldots \ldots$

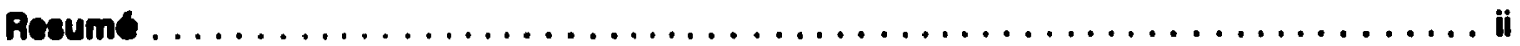

Acknowledgememts $\ldots \ldots \ldots \ldots \ldots \ldots \ldots \ldots \ldots \ldots \ldots \ldots \ldots \ldots \ldots \ldots$ iii

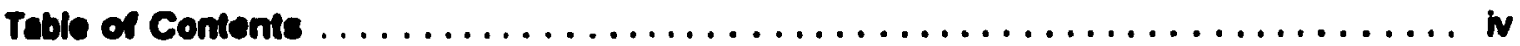

Lit of Flgures $\ldots \ldots \ldots \ldots \ldots \ldots \ldots \ldots \ldots \ldots \ldots \ldots \ldots \ldots \ldots \ldots \ldots \ldots \ldots$

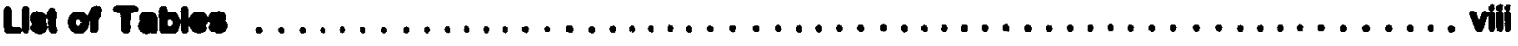

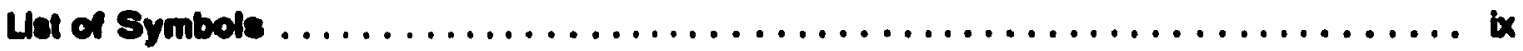

1. Introduction $\ldots \ldots \ldots \ldots \ldots \ldots \ldots \ldots \ldots \ldots \ldots \ldots \ldots \ldots \ldots \ldots \ldots \ldots \ldots$

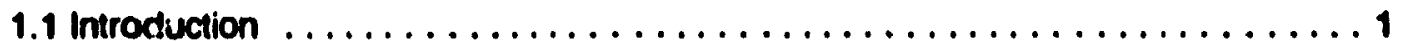

1.1.1 Ductile Floxural Walls . . . . . . . . . . . . . . . . . 1

1.2 Analysis of Coupled Wall Systems $\ldots \ldots \ldots \ldots \ldots \ldots \ldots \ldots \ldots \ldots \ldots$

1.2.1 Equivalent Lamina Analysis of Coupled Flexural Walls ..... . . . . 2

1.2.2 Equivalent Frame Method of Modelling Coupled Flexural Walls . . . . . . 6

1.3 Previous Research . . . . . . . . . . . . . . . . . . . . . . . . . 7

1.3.1 Tests of Rointorced Concrete Coupling Beams and Coupled Walls . . . . 7

1.3.2 Steel Link Bearns in Eccenticelly Braced Frames . . . . . . . . . . . . . . 8

1.3.3 Reinforced Concrete Coupling Beams Containing Encased

Sreel Mernbers ...............................

1.3.4 Embedded Connections of Siructural Steel Members in

Reiniorced Concrete ....................... 12

1.4 Objectives of Research Programme $\ldots \ldots \ldots \ldots \ldots \ldots \ldots \ldots \ldots \ldots \ldots \ldots$

2. Prototype structure $\ldots \ldots \ldots \ldots \ldots \ldots \ldots \ldots \ldots \ldots \ldots \ldots \ldots \ldots \ldots \ldots \ldots \ldots \ldots \ldots \ldots$ 14

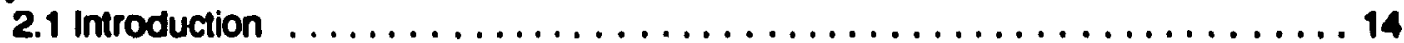

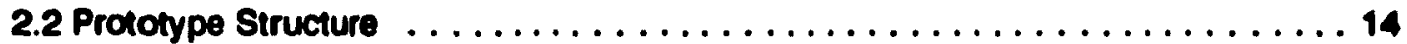

2.2.1 Material Propenties .......................... 15

2.2.2 Loading on the Structure $\ldots \ldots \ldots \ldots \ldots \ldots \ldots \ldots \ldots \ldots \ldots . \ldots . \ldots \ldots$

3. Specimen Declon and Detalling ............................. 19

3.1 Design of the Sted Link Bean and Embedment Region . . . . . . . . . . . . . . 19

3.1.1 Design of the Exposed Spen of the Link Beam . . . . . . . . . . . . . 19

3.1.2 Design of the Reinlorced Concrete Embedment Region ........ 21

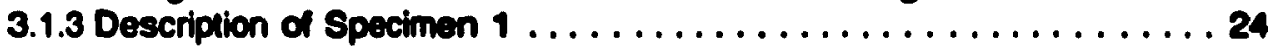

3.1.4 Refinements to the Design Procedure for Specimen $2 \ldots \ldots \ldots$

3.1.5 Description of Specimen $2 \ldots \ldots \ldots \ldots \ldots \ldots \ldots \ldots \ldots \ldots \ldots \ldots . \ldots \ldots$

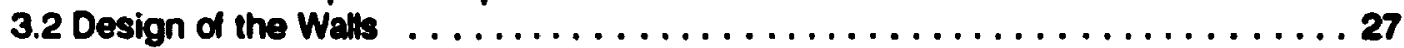

3.3 Material Properties . . . . . . . . . . . . . . . . . . . . . . 28

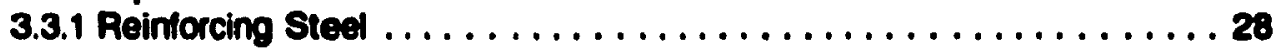

3.3.2 Concrete . . . . . . . . . . . . . . . . . . . . . . . . 29

3.3.3 Link Beam Sted . . . . . . . . . . . . . . . . . . . . 30 


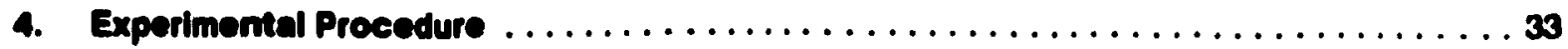

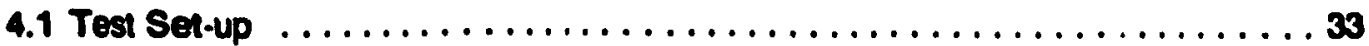

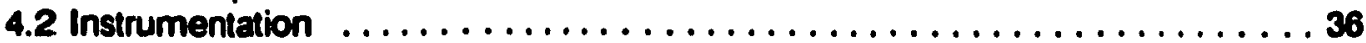

4.3 Loading History $\ldots \ldots \ldots \ldots \ldots \ldots \ldots \ldots \ldots \ldots \ldots \ldots \ldots \ldots \ldots$

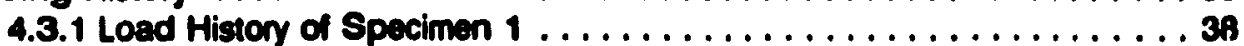

4.3.2 Load History of Specimen $2 \ldots \ldots \ldots \ldots \ldots \ldots \ldots \ldots$

5. Experimental Results $\ldots \ldots \ldots \ldots \ldots \ldots \ldots \ldots \ldots \ldots \ldots \ldots \ldots \ldots \ldots \ldots \ldots \ldots$ \&

5.1 Specimen $1 \ldots \ldots \ldots \ldots \ldots \ldots \ldots \ldots \ldots \ldots \ldots \ldots \ldots \ldots \ldots \ldots \ldots \ldots \ldots \ldots$

5.1.1 Link Beam Response ....................... 43

5.1.2 Reinforced Concrete Response $\ldots \ldots \ldots \ldots \ldots \ldots \ldots \ldots \ldots \ldots$

5.1.3 Hysteretic Response ......................49

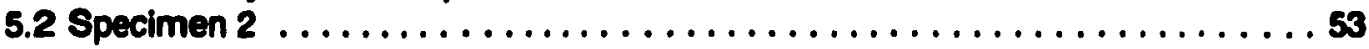

5.2.1 Link Beam Response ....................... 54

5.2.2 Reinforced Concrete Response .................. 56

5.2.3 Hysteretic Response $\ldots \ldots \ldots \ldots \ldots \ldots \ldots \ldots \ldots \ldots \ldots$. . . . . . . 59

6. Comparieon of the Reaponses of Specimene 1 and $2 \ldots \ldots \ldots \ldots \ldots \ldots \ldots \ldots$

6.1 Comparison of Predicted and Experimental Values ...............64

6.2 Hysteretic Responses . . . . . . . . . . . . . . . . . . . . . . 65

6.3 Response of the Link Beams ........................69 69

6.4 Response of the Reinforced Concrete Embedment Regions . . . . . . . . . 70

6.5 Displacement Contributions of the Embedment Regions ............. 71

7. Ascesemem of Porformance of Steet Link Beams Coupling Rolmforeed Conerete Walis . 75

7.1 Comparisons with Reinforced Concrete Coupling Beams ............ 75

7.2 Comparisons with Steet Link Beams in Eccentrically Braced Frames . . . . . . . 76

8. Conclualons and Recommendations $\ldots \ldots \ldots \ldots \ldots \ldots \ldots \ldots \ldots \ldots \ldots$

8.1 Areas for Funther Investigation $\ldots \ldots \ldots \ldots \ldots \ldots \ldots \ldots \ldots \ldots \ldots$.

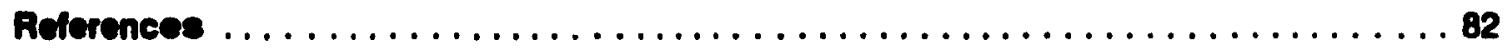

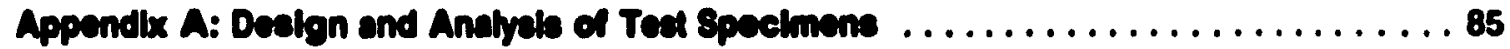

A.1 Design of Steet link Beam with Specilied Material Propenties . . . . . . . . . . . 86

A.2 Anahysis of link Beams whth Actual Meserial Propenties . . . . . . . . . . . . 89

A.3 Design of Reinforced Concrete Embedmemt Regions . . . . . . . . . . . . 91

Appendix B: Summary of Loads and deflectlons at the Paak Load Stages . . . . . . . . 93 


\section{List of Figures}

\section{Chapter 1}

1.1 Equivalent lamina representation of coupled shear walls . . . . . . . . . . . . . . 4

1.2 Equivalent frame representation of coupled shear walls $\ldots \ldots \ldots \ldots \ldots \ldots \ldots \ldots$.

1.3 Diagonal reinforcement in coupling beams ....................... 8

1.4 Load versus deflection curves for link beams with span to depth ratios of $2.5 \ldots \ldots \ldots 10$

\section{Chapter 2}

2.1 Protonpe Structure $\ldots \ldots \ldots \ldots \ldots \ldots \ldots \ldots \ldots \ldots \ldots \ldots \ldots \ldots \ldots \ldots \ldots$. 15

2.2 Shears in the coupling beams determined from equivalent lamina and equivalem frame analyses

\section{Chapter 3}

3.1 Assumed strain and stress distributions nver the embedment .............22

3.2 Reinforcing steel requirement across the flange-concrete interface $\ldots \ldots \ldots \ldots \ldots \ldots$. 23

3.3 Details of link beam Specimens 1 and $2 \ldots \ldots \ldots \ldots \ldots \ldots \ldots \ldots \ldots \ldots \ldots$

3.4 Eflective length of the embedment $\ldots \ldots \ldots \ldots \ldots \ldots \ldots \ldots \ldots \ldots \ldots \ldots$

3.5 Details of the reinforcing cage of both specimens $\ldots \ldots \ldots \ldots \ldots \ldots \ldots \ldots \ldots \ldots 28$

3.6 Reintorcing cage and link beam of Specimen $1 \ldots \ldots \ldots \ldots \ldots \ldots \ldots \ldots$

3.7 Stress-strain relationships for concrete used in Specimens 1 and $2 \ldots \ldots \ldots \ldots \ldots . \ldots 30$

3.8 Stress-strain relationships for web steels used in Specimens 1 and $2 \ldots \ldots \ldots \ldots . .31$

\section{Chaperer 4}

4.1 Test set-up $\ldots \ldots \ldots \ldots \ldots \ldots \ldots \ldots \ldots \ldots \ldots \ldots \ldots \ldots \ldots \ldots \ldots \ldots \ldots \ldots \ldots . \ldots . \ldots \ldots$

4.2 Method of simulating actual coupled wall response $\ldots \ldots \ldots \ldots \ldots \ldots \ldots \ldots \ldots$. 35

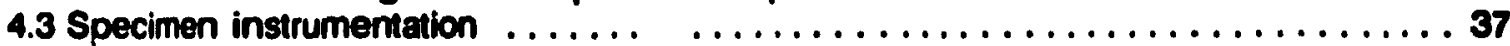

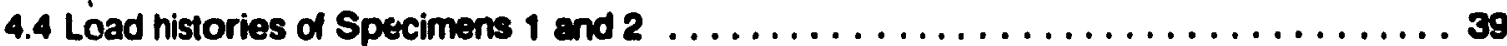

\section{Chapler 5}

5.1 Link bearn shear versus relative ventical displacement of Specimen $1 \ldots \ldots \ldots \ldots \ldots$

5.2 Specimen 1, atter testing . . . . . . . . . . . . . . . . . . . . . . . . 43

5.3 Measured strains in the link beem flange of Specimen $1 \ldots \ldots \ldots \ldots \ldots \ldots \ldots \ldots . \ldots 4$

5.4 View of east embedment of Specimen 1 with cover concrete removed . . . . . . . . . . 45

5.5 View of east end of link beam of Specimen 1 ater removal from concrete . . . . . . . . . 46

5.6 Overall view of link beam of Specimen 1 eter removal from the walls . . . . . . . . 46

5.7 Ahernating compression zones dwo to reversed cyclic loading ............. 47

5.8 East embedment region of Specimen 1 at peak losd $48 \ldots \ldots \ldots \ldots \ldots \ldots \ldots \ldots .48$

5.9 East embedmem region of Specimen 1 a pest loed $154 \ldots \ldots \ldots \ldots \ldots \ldots \ldots \ldots . . . .49$

5.10 Vertical plane of cracking a east embedment region of Specimen 1 at peak load $21 \mathrm{~A} 50$

5.11 Crack pattern on east well of Specimen 1 a peak load $238 \ldots \ldots \ldots \ldots \ldots \ldots \ldots 51$

5.12 East embedment region of Specimen 1 an peak load $248 \ldots \ldots \ldots \ldots \ldots \ldots \ldots \ldots$. . . . 52

5.13 Link beam shear versus relative verical displacement of Specimen $2 \ldots \ldots \ldots \ldots$

5.14 Specimen 2, atter resting ................................ 54

5.15 Overall view of link beem of Specimen 2 at end of leating showing severe web buckingss

5.16 Shear versus shear strain response of embedded web regions of Specimen 2 ..... 57

5.17 Overall view of link beam of Specimen 2 enter removal from the walls $\ldots \ldots \ldots \ldots \ldots 56$

5.18 East embedment region of Specimen 2 a peak load $83 \ldots \ldots \ldots \ldots \ldots \ldots \ldots \ldots$. 58

5.19 East embedment region of Spectmen 2 ex peak load $158 \ldots \ldots \ldots \ldots \ldots \ldots \ldots \ldots$. . . . . 59

5.20 failure plane at east embedment region of Specimen 2 a peak load $18 A$. . . . . . . 60

5.21 Crack pattern on east wall of Specimen 2 a peak load $22 A \ldots \ldots \ldots \ldots \ldots \ldots \ldots 6$ 
5.22 Crack pattern on west wall of Specimen 2 at peak load 22 A . . . . . . . . . . . . 62

5.23 West embedment region of Specimen 2 at peak load $224 \ldots \ldots \ldots \ldots \ldots \ldots \ldots \ldots$

\section{Chapter 6}

6.1 Link beam shear versus relative displacement of Specimens 1 and $2 \ldots \ldots \ldots \ldots 6$

6.2 Applied shear versus displacement envelope at $4 \delta_{y} \ldots \ldots \ldots \ldots \ldots \ldots \ldots \ldots \ldots$

6.3 Applied shear versus displacement envelope at $88_{y} \ldots \ldots \ldots \ldots \ldots \ldots \ldots \ldots$

6.4 Cumulative energy dissipation of Specimens 1 and $2 \ldots \ldots \ldots \ldots \ldots \ldots \ldots \ldots$

6.5 Equivalem elastic damping coeflicients of Specimens 1 and $2 \ldots \ldots \ldots \ldots \ldots \ldots$

6.6 Link beams of Specimens 1 and 2 anter removal from the walls . . . . . . . . . . . 71

6.7 Strains in the longitudinal reinforcing bars at the inside face of the east wall . . . . . 72

6.8 Contribution of the displacement of the link beams $\ldots \ldots \ldots \ldots \ldots \ldots \ldots \ldots \ldots$

\section{Chapter 7}

7.1 Equivalent elastic damping coefficients of Specimens 1 and 2 and

reinforced concrete coupling beams . . . . . . . . . . . . . . . . . . 76

7.2 Shear versus link beam rotation in an eccentrically braced frame $\ldots \ldots \ldots \ldots \ldots \ldots 77$

7.3 Equivalent elastic damping coefficients of Specimens 1 and 2 and steel link beam

in an eccentrically braced frame $\ldots \ldots \ldots \ldots \ldots \ldots \ldots \ldots \ldots \ldots$ 
Lust of Tables

Chapter 2

2.1 Summary of link beam shears and horizontal deflections from preliminary analyses . . . 17

Chapter 3

3.1 Properties of reinforcing steel

29

3.2 Properties of concrete $\ldots \ldots \ldots \ldots \ldots \ldots \ldots \ldots \ldots \ldots \ldots \ldots \ldots \ldots \ldots, \ldots \ldots$

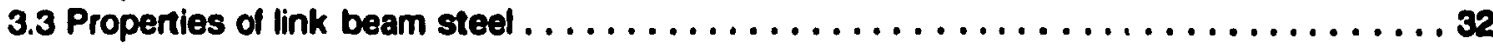

Chapter 5

5.1 Summary of critical load stages

41

Chapter 6

6.1 Comparisons of predicted and experimental values

65

viii 


\section{List of Symbols}

$A_{1}, A_{2}$ area of single wall in coupled system $\left(\mathrm{mm}^{2}\right)$

A cross sectional area of link beam (mm?)

A area of link beam stiffener $\left(\mathrm{mm}^{2}\right)$

A. area of link beam web $\left(\mathrm{mm}^{2}\right)$

b width of link beam flange $(\mathrm{mm})$

b' effective width of compression block at link beam flange $(\mathrm{mm})$

c depth of concrete cover $(\mathrm{mm})$

E Young's modulus of material (MPa)

e lever arm of load applied to erribedment ( $\mathrm{mm}$ )

f shape factor for shear stress distribution (laminar analysis)

$f_{c}^{\prime}$ compressive strength of concrete (MPa)

$f_{\text {sp }} \quad$ splitting strength of concrete (MPa)

$F_{y} \quad$ ultimate strength of steel (MPa)

$F_{y} \quad$ yield strength of steel (MPa)

$h$ height of link beam ( $\mathrm{mm})$

$h_{w}$ height embedment web ( $\mathrm{mm}$ )

$\mathrm{I}_{11} \mathrm{I}_{2}$ moment of inertia of single wall in coupled system ( $\mathrm{mm}$ )

$I_{b} \quad$ moment if inertia of link beam $(\mathrm{mm})$

I. moment of inertia of entire coupled wall system ( $\mathrm{mm}^{\mathrm{t}}$ )

Ix reduced moment of inertia of link beam allowing for shear deflection ( $\left.\mathrm{mm}^{\prime}\right)$

L clearspan of link beam $(\mathrm{mm})$

$L_{a} \quad$ maximum unsupported length of link beam ( $\mathrm{mm}$ )

4. required lengin of embedment (mm)

Lom effective clearspan of link beam (mm)
$M_{1} \quad$ factored moinent $(\mathrm{kN} \cdot \mathrm{m})$

$\mathrm{M}$, factored moment resistance (kN・m)

P point load applied to top of structure (kN)

R force modification factor (NBCC, 1990)

$r \quad$ radius of gyration $(\mathrm{mm})$

$t$ thickness of link beam flange (mm)

4. thickness of embedment web (mm)

$\mathrm{T}_{x}$ axial force in wall at level $\times(\mathrm{kN})$

$\checkmark$ equivalent seismic base shear (NBCC, 1990) (kN)

$V_{c}$ shear resistance of embedment (kN)

$V_{1} \quad$ factored shear (kN)

V. factored shear restatance (kN)

W, unilormly distributed lateral load on structure ( $\mathrm{kN} / \mathrm{m})$

w thickness (width) of link beam web (mm)

W lirisarly distributed lateral load on structure $(\mathrm{kN} / \mathrm{m})$

$x$ distance measured from top of structure (laminar analysis) (m)

$z$ section modulus ( $\mathrm{mm}$ )

$\beta$ equivalent elastic damping coefficient

$\gamma_{p}$ rotation of link beam in eccentrically braced frame, from Engelhardt and Popov (1989)

by risplacement at yield $(\mathrm{mm})$

$\phi \quad$ resistance factor for steel $(0.90)$

$\Phi_{c}$ resistance factor for concrete (0.60)

Ф. resistance factor for reiniorcing steel (0.85)

$\mu \quad$ ductility 


\section{Chapter 1 \\ Introduction}

\subsection{Introduction}

The Supplement to the 1090 Netional Building Cods of Cencda (NBCC Euppiement, 1000) states that an ecceptable level of public setety can be schioved if structures are designod auch that they are "able to reciat modercte earthquakes without significant demage and major earthquakes without collepeer. The 1990 NBCC specifies en equivelent sciemic bese shoer, $V$, which is celculated from the following expression:

$$
v=\left(\frac{V_{0}}{R}\right) u
$$

where $U=$ a calbration factor, taken $\mathbf{e s} 0.6$,

$R=$ force modification fector, and

$V_{0}=$ equivelent elastic base shear, given as: $V_{0}=$ VSIFW with:

$v=20$ end relocily retio,

$S=$ seivmic reapoino fector,

1 = importence fector,

$F=$ foundetion fector, and

$W=$ the weight of the etructure

The force modification factor, $R$, reflects the abiliny of a structure to diasipete eneroy through inelastic betheviour. In the 1990 NBCC the valuses of $R$ vary from 1.0, for unreintorced masonry, to 4.0, for ductile moment reaisting sted or concrete freme etructures.

\subsubsection{Duetlie Floxural Wolle}

The 1990 NBCC, recognises that ductile flexurel walk ere cepeble of exhibling significant inelastic deformations without loss of strength and specilies a force modivication factior, A, of 3.5. 
Ductile Hexural walls are deaigned in accordence with the requirements of CSA Stenderd CAN3. A23.3-MB4, Design of Concrete Sinctures for Buildings (CSA, 1884). The Special Provisions for Seismic Design, Clause 21, state that ductile floxural walls must be designed to restio the forces and dissipate energy through flexural yielding at one or more plastic hinges. This is achieved by designing the walls to yield in flexure without local instability or shear fallures. Funthermore. atringent requirements are pleced on the flexurel ductility of the walls, the detailing of the well reinforcement and the minimum emounts of reinforcement in the walls.

Wals with a reguler pentem of openings ere celved coupled weis. They are conposed of two or more walls linked whth coupling besms sbove and below each opening. Ductle coupled Nexural walls are designed auch that the coupling beams are the primary eneroy diasipating elements. This is achieved in the CSA A23.3 Standard by first designing the coupling beams such that shear failures are avoided and by detalling the coupling beams to enable full yisting of the main reiniorcement. The Standard requires that ductle coupling beams be reintorced with well confined diegonal reintorcement or, when the shear stress is low and the epan-10-depth ruto is reletwely high, then the beans may be designed and detalled as ductile flexural beams. in order to ensure that the beams are cepeble of dialpating significant emounts of energy, the walle are designed to resist the forces corresponding to hinging in all of the beams. Therefore a ductle coupled flexural wall gystem is sble to discipete sionificant amounts of energy by hinging of the coupling beams without significant inelastic action occurring in the walls.

\subsection{Analyale of Coupled Wall Syetems}

It is clear from their function thet the coupling beams in a coupled wall syutem are the critical energy absorbing elements and thus their strength will dictate the required atrengths of the walls. The first step in the desion is to determine the forces in the coupling beams due to lateral loading.

The equivalent lamina method and the equivalent frame method are the most common methods of enshysing coupled shear walls. These two methods of anabysis are discussed bolow.

\subsubsection{Equivalem Lemina Analyels of Coupled Floxurat Wolle}

The determination of the forces in the coupling beams of a coupled fexural wall system is highly staticelly indeterminate. In order to enalyse the system, the link beams are repleced with an equivalent elastic lamina as shown in Fig. 1.1. The forces in the coupling beams can be 
determined from a single, second order diilerentiel equation when the following assumptions are made:

D) the fioor heights are uniform, so that the link beems ere equelly spaced,

ii) The link beams all have the same properties, with the exception of the topmost one, whose stifiness is assumed to be one hall the stimneas of the other beams,

ii) the propenties of the walls do not vary with hoight

iv) the axial deformations of the link beams are neglected,

v) the shear delormations of the wells are neglected,

vi) The stifinesses of the walls are seaumed to be much greater then thet of the link beams, consequently the slopes of the wells are the seme at any lovel, implying that the points of contrallexure in the link beams are at their midspans, and

vi) The lateral load can be expressed as a continuous function over the helght of the structure.

The differential equation, based on conditions of equinbrium and competbitiny was expressed by Roemen (1864) as the relutionship between the external moment, $M_{0}$ the exial force in the well, $T_{n}$ and the laminar sheser force, $q_{\text {n }}$ at any level of the wall, es:

$$
\frac{1}{E I_{0}} \int_{x}^{n} M_{0} d x-\frac{1^{2}}{E I_{0}} \int_{x}^{N} T_{x} d x-\frac{1}{E}\left(\frac{1}{A_{1}}+\frac{1}{A_{2}}\right) \int_{x}^{N} T_{x} d x-\frac{M l_{0}^{O}}{12 E I_{x}} q_{x}=0
$$

with

$$
I_{2}=\frac{1}{1+\frac{12 E V^{5}}{c A d_{b}^{2}}}
$$

whore

$x=$ the distence mescured from the top of the structure,

$I_{\mathrm{a}}$ - the reduced moment of inertia of the couping beam ellowing for shear doformution.

$A_{0}=$ crose-sectional erea of the beam,

$b$ = moment of ineria of the beem,

1 - shepe fector to eccount for the shaer streas dietribution in link beem, and $I_{01} A_{1}, A_{2}, I_{1}, 6$ ere geometric properties of the syatem es defined in Fig. 1.1. 


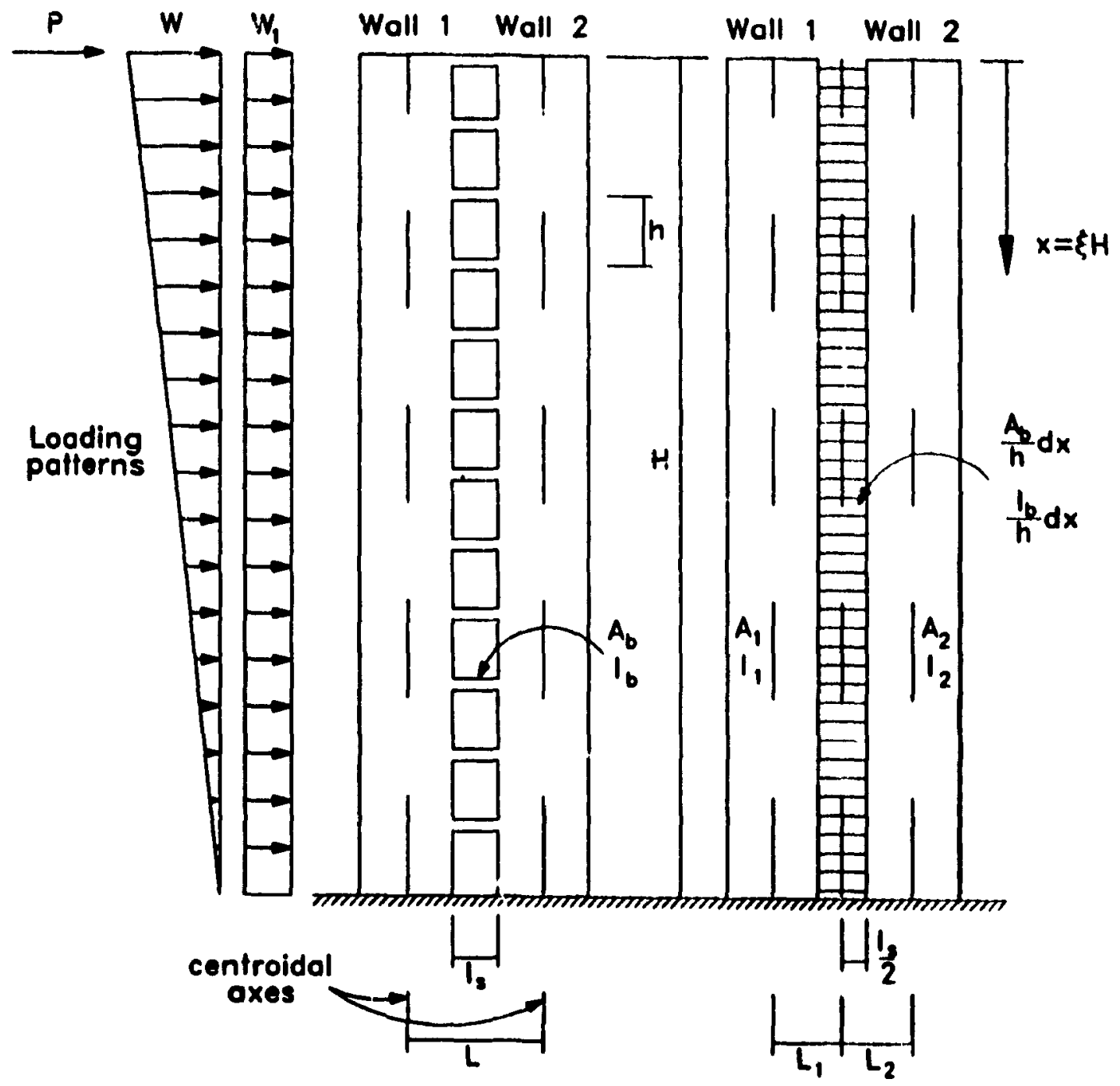

Figure 1.1 Equivalem lanina representation of coupled shear walls (adapled from Staflord-Smith and Coull, 1991)

Combining the common terms and differentiating with respect to $x$, the differentide equation for the axial force in the walls is obtained as:

$$
\frac{d^{2} T_{x}}{d x^{2}}-a^{2} T_{x}=-\gamma M_{0}
$$

Where $T_{\mathbf{n}}$ is the axial force in the wall at $x$ and;

$$
a^{2}=\left(\frac{1}{A_{1}}+\frac{1}{A_{2}}+\frac{I^{2}}{l_{0}}\right)\left(\frac{12 I_{2}}{m_{0}^{2}}\right) \quad \text { and } r=\frac{12 N_{x}}{1 N_{b}^{2}}
$$


Considering the following three loading patterns on the shear wall, as shown in Fig. 1.1:

1) A single point load, P applied to the top of the shear wall,

ii) A linearty distributed load, $W$ acting with maximum intensity at the top of the ii) A uniformb distributed load, $W_{v}$.

The bending moment at any level due to these loads is:

$$
M_{0}=W H\left(E^{2}-\frac{t^{3}}{3}\right)+P H E+W_{1} H \frac{t^{2}}{2}, \text { whore } E=\frac{x}{H}
$$

Considering that each wall has a fully fixed base, the boundary conditions become:

1) when $x=0, T=0$ (1.e., at the top of the structure) and,

ii) when $x=H, q=0$, that is $0 T / d x=0$ (i.e., at the base of the structure)

Substituing these conditions into the differential equation, the axial force, $T_{\text {so }}$ can be found. Recognising that the axial force is the accumulation of laminar shear, the equation for laminar shear cen be writen as (Santhakumar, 1974):

$$
q(\xi)=\left(\frac{d T(\xi)}{d \xi}\right)\left(\frac{1}{H}\right)
$$

Defining the following parameters as:

$$
p=a, \quad p=\frac{P}{W} \text { and } p^{\prime}=\frac{W_{1}}{W}
$$

and substhuting these parameters, together with Equation 1.6, into Equation 1.1 results in the following expression for the laminar shear:

$$
\sigma(\xi)=\left(\frac{y W H^{2}}{p^{2}}\right)\left(\begin{array}{c}
\left(2+p^{\prime}\right) \tanh \beta \cosh \beta \xi+\frac{\cosh \beta \xi}{\cosh \beta}\left(\frac{2}{\beta}-\beta-\rho^{\prime} \beta-\rho \beta\right) \ldots \\
-\left(2+p^{\prime}\right) \sinh \beta E+2 \beta E-\beta \xi^{2}+\beta p+\beta p^{\prime} \xi-\frac{2}{\beta}
\end{array}\right)
$$

The lateral deflection of the shear well, at any lovel, $x_{1}$ can be derived from the generd expression:

$$
E_{0} \frac{d^{2} y}{d x^{2}}=W_{0}-! T_{x}
$$


which can be expressed as:

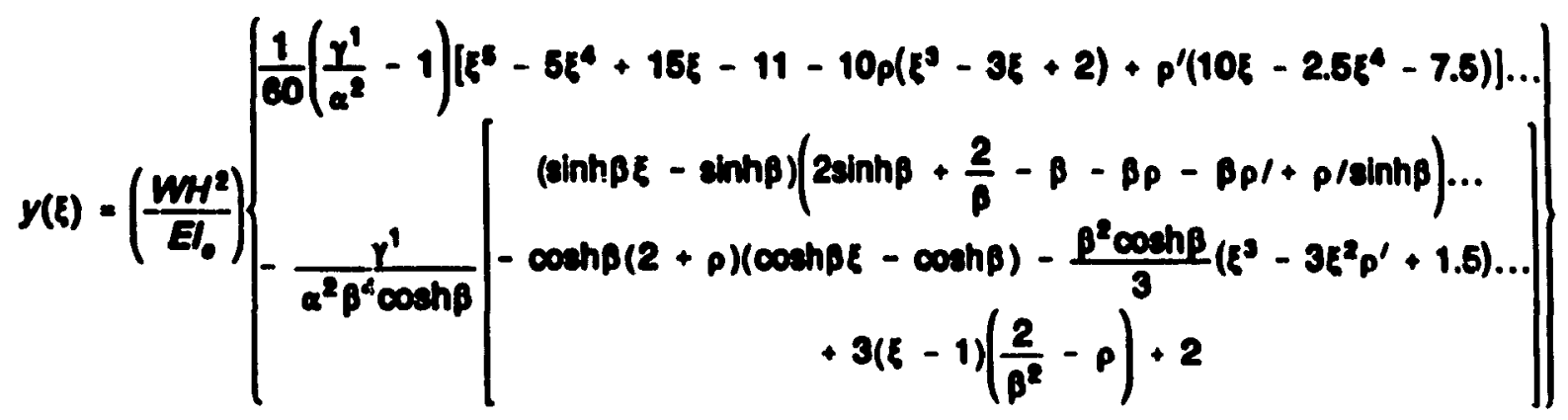

\subsubsection{Equivalent Frame Method of Modelling Coupled Flexural Walle}

While the equivalent lamina analysis is appropriate for uniform flexural walls, $h$ is unable to adequately deal with more complex systems. An equivalent frame analysis (MacLeod, 1966 and Schwaighofer and Microys, 1969), provides a more realistic and more versatile arproach for more complex systems.

An equivelent frame model repreecents each wall whin an equivalent 'wide column' locased at the centroldal axks of the well. The axial rigidity, EA, and the flexural riglitin, El, of each wall is assigned to a column of the equivalent frame. Typically, shear deformations in the walls are neglected since the flexural behewbur will dominate the response of the walls.

The coupling beams are represented by frame elements located at the centroidal axis of each coupling beam. In order to accoum for shear deformations of the coupling beam, the moment of inentia assigned to each beam member is determined from the relation given by Equation 1.2. Rigid offects spen from the centroidal axes of the walls (equivalent column) to the ends of each coupling bean. These rigid ofisets simuleate the 'wide column' effect and seatsty the assumption that plane sections in the walls remain plane. The rigid offsets ensure that the correct rotations and verical displacements are produced at the ends of the coupling beams. Figure 1.2 illustrates the representation of a coupled wall system as an equivalent frame.

The equivalem frame method has the additional advantage that the coupled wall system can be linked with the rest of the structure, enabling the structural interaction to be determined.

The prototype structure presented in Chapter 2 was analysed using both the equivalent lamina and equivalent frame methods and some comparalive results are shown in Fig. 2.2. 


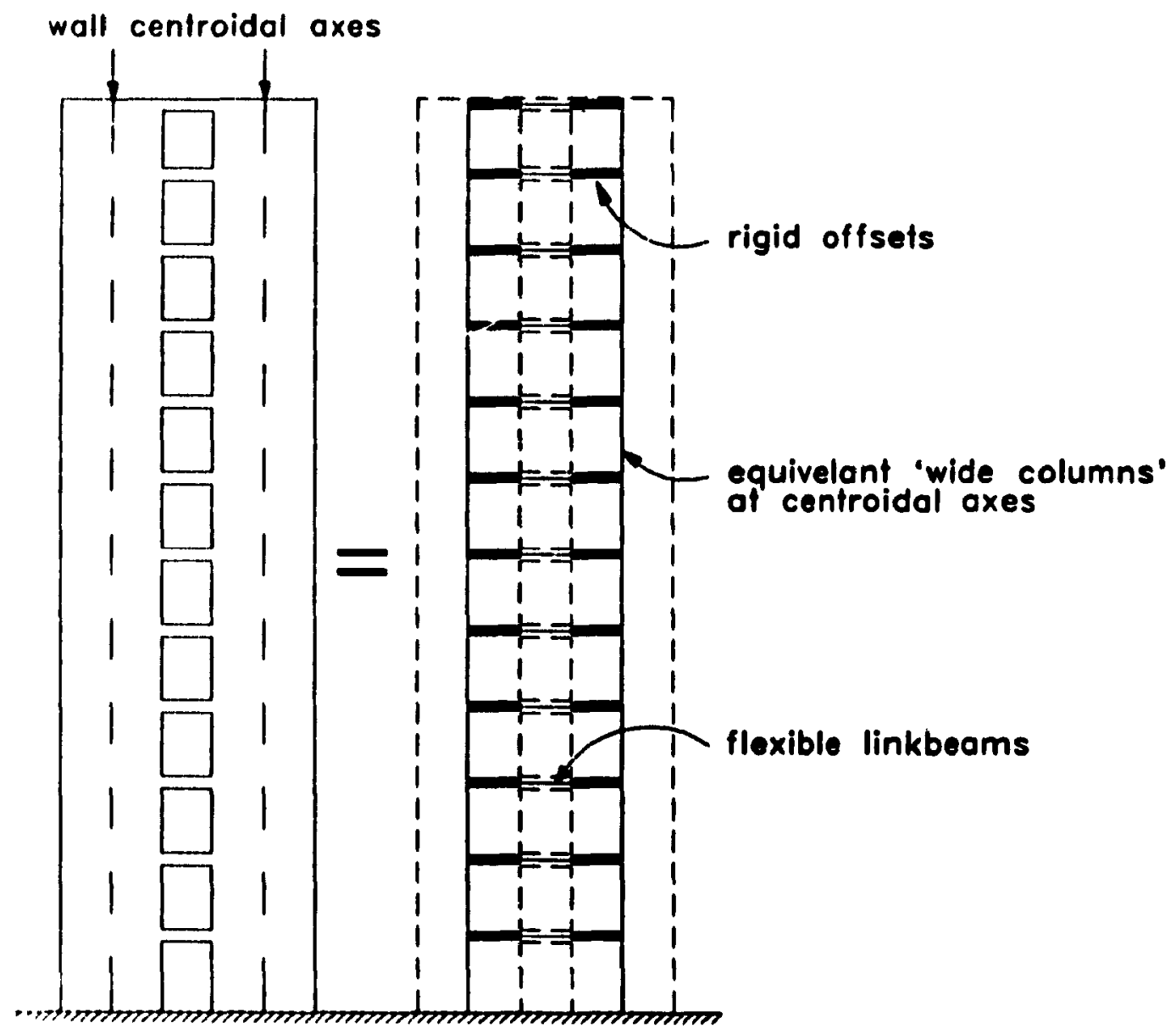

Figure 1.2 Equivalent frame representation of coupled shear walls (adepled from Stallord-Smith and Coull, 1991)

\subsection{Previous Research}

\subsubsection{Teats of Rolinforced Conerete Coupling Beame and Couplad Walle}

Following the 1964 Alasken earthquake, (Berg and Strata, 1984) considerable ettention was devoted to improving the response of reinforced concrete coupling beams in coupled wall systems.

Extensive experimental work, under the direction of Paulay at the University of Canterbury, led to the devetopment of design guidelines for reinforced concrete coupling beams. Teats conducted by Paulay (1969 and 1971) led to design quidelines for coupling beams with relathely 
large span-10-depth ratios and relativety low shear atress lovels. The deaign philosophy developed for these members avoids britte shear fallures by providing shear resistences large enough to develop foxurel hinging in the beams (Park and Paulay, 1975). Conventionaly reinforced beams with relatively small span-lo-depth retios and/or high shear streas levels exhibited sliding-shear fallures at the wall intertaces (Paulay and Binney, 1974 and Park and Paulay, 1975). Because the sliding-shear plane is perpendicular to the beam spen, conventional transverse reintorcement has no effect in controling this mode of feikure.

To prevent sliding-shear failures, Paulay and Binney (1974) introduced the concept of using diagonal reinforcement in the coupling beams (see Fig 1.3). Diagonally reinforced coupling

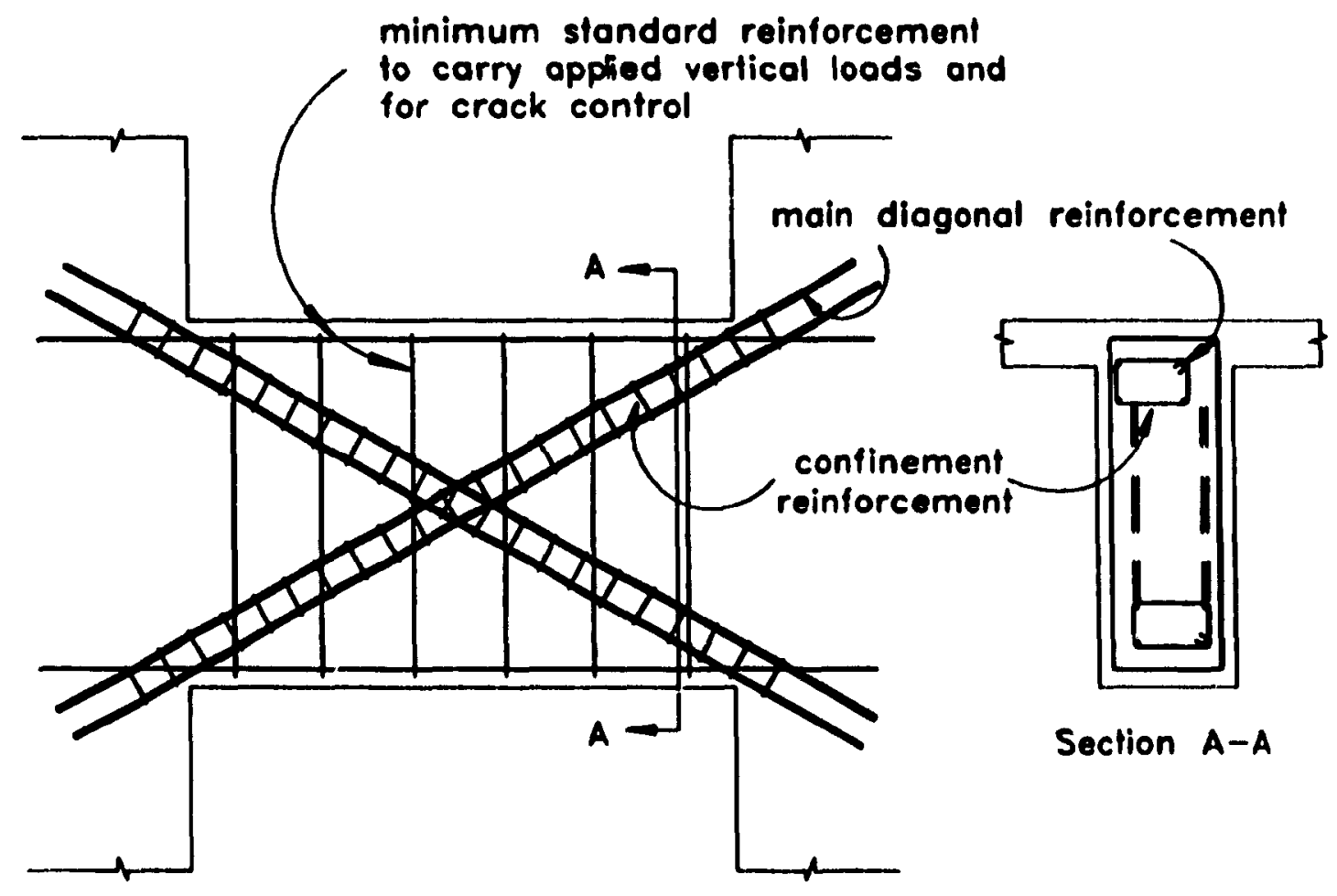

Figure 1.3 Diagonel reinforcement of coupling beams

beams offered improved ductility and energy absorption over comventionally reinforced coupling beams. Santhakumar and Paulay (1974) conducted quanter-scale model tests on seven storey coupled walls having coupling beams with a span-tb-depth ratio of 1.25. These tests confirmed the superior performance of diagonally reinforced coupling beams, with the anainment of larger displacement ductilties end energy absorption compered whi conventionally relniorced coupling 
beams. With the diagonally reinforced beams, dieplecement ductilities of the wall system of 8 to 13 were achieved without loss of atrength.

The Univerainy of Canterbury research forms the bask for the daign criteria for coupling beams in ductile coupled flexurel walls given by the CSA $A 23.3$ Sienderd.

Research conducted at the Pontand Cement Association (PCA) exemined the rutense of relatively stender coupling basms, having span to depth retios of 2.5 and 5 (Bhiu, ct al, 1978). These tests confirmod the improved beheviour of diegonelity reintorced beems over conventionely reinforced beams (see Fig. 1.4). However these teets demonetresed thit for larger span to depth ratios the diegonal reinforcernem is not as efliciem dus to th lower inclination. These teats also contirmed the need for closely speced hoops or spird reinforcement confining the disgonel bers, both in the coupling beam and along their wall embedments. If adequete confinement is not provited, then buckling of the diagonal bars may severely affect the response.

\subsubsection{Steol Llnk Beams in Eccomirically Breced Framse}

Analogous to coupling beams in reinforced concrete coupled wall aystems, steel link beams in eccentrically breced frames (EBFs) serve as the primery ductile eneroy cbsorbing elements. Recent research has shown the seet link beems in eccentricaly breced fremes can be detailed to provide excellent ductiny and eneroy diesipening cherecterbetices.

A number of research progremmes, under the direction of Popov, have been carried out at the University of California, Berkeley (Malley and Popov, 1983a and 1883b, Roeder and Popov, 1978 and Kasai and Popov, 1986). The resulve of these programs have led to decign recommendations for achieving large ductility and energy absorption characteristics from link beams. Engelhard and Popor (1989) provide an excelient summary of deaign and detalling considerations for achieving ductile response from steel ink beams of venying spans.

This research clearly indicates the superior hysteretic reaponse of seel beems penticularty when they are designed to yield in shear while remeining elactic in flexure. Malley and Popov (1983b) demonstrate the necesshy for detaling ink beams to control web and/or fiange instablity with the provision of stilieners.

This work has led to the design and detalling requirements for link beams in EBFs that form the basis of the provisions of Appendix D in the Canadian Steel Deaion Standard, CANCSA S-16.1-M89 (CSA, 1989).

\subsubsection{Rolntorced Conercte Couplling Boams Containing Encased Steet Mombers}

Allhough no experimental research hes been published on the use of steel beams to connect reinforced concrete walls, there have been some investigations carried out on reinforced 


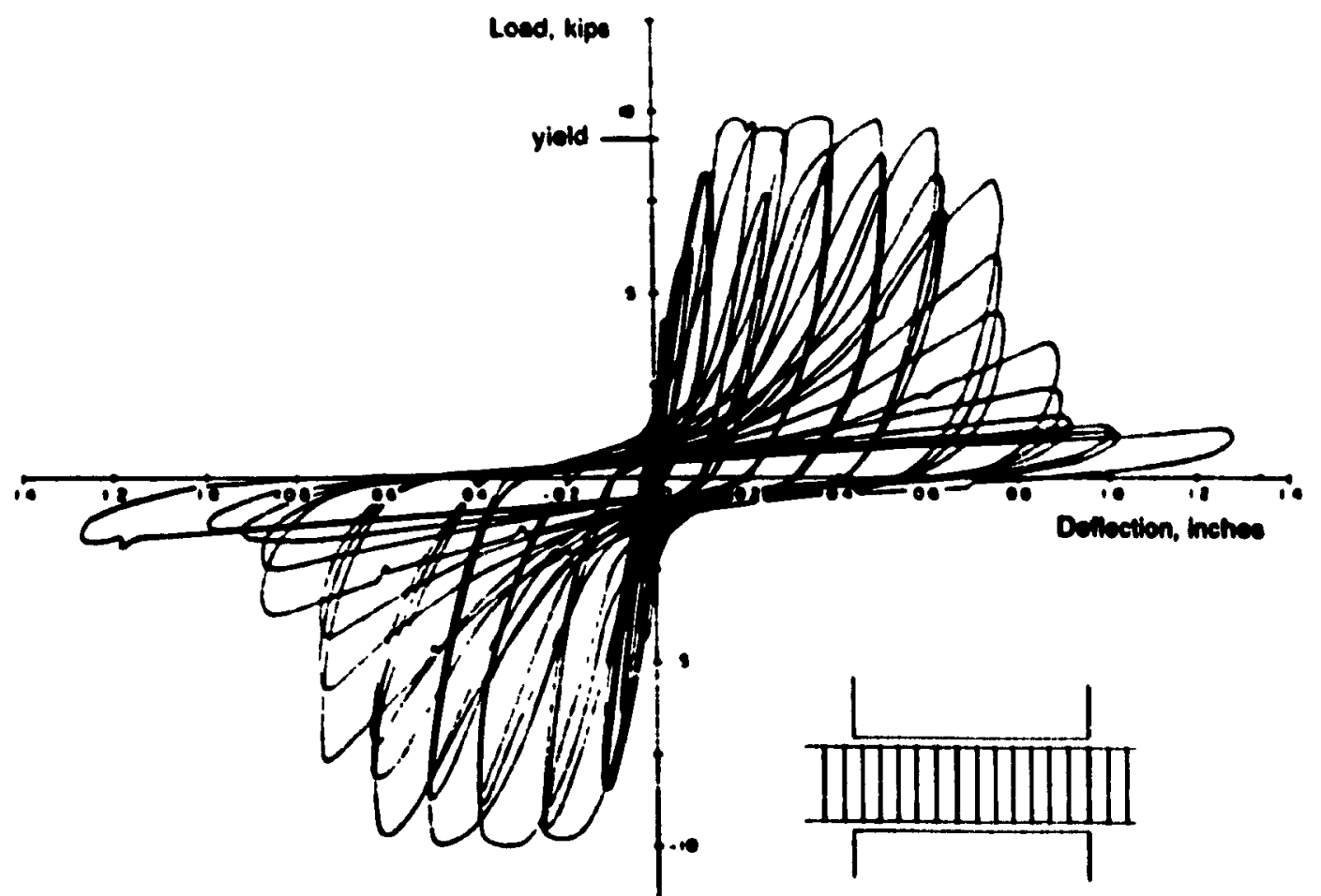

(a) Comentionaly reinforced

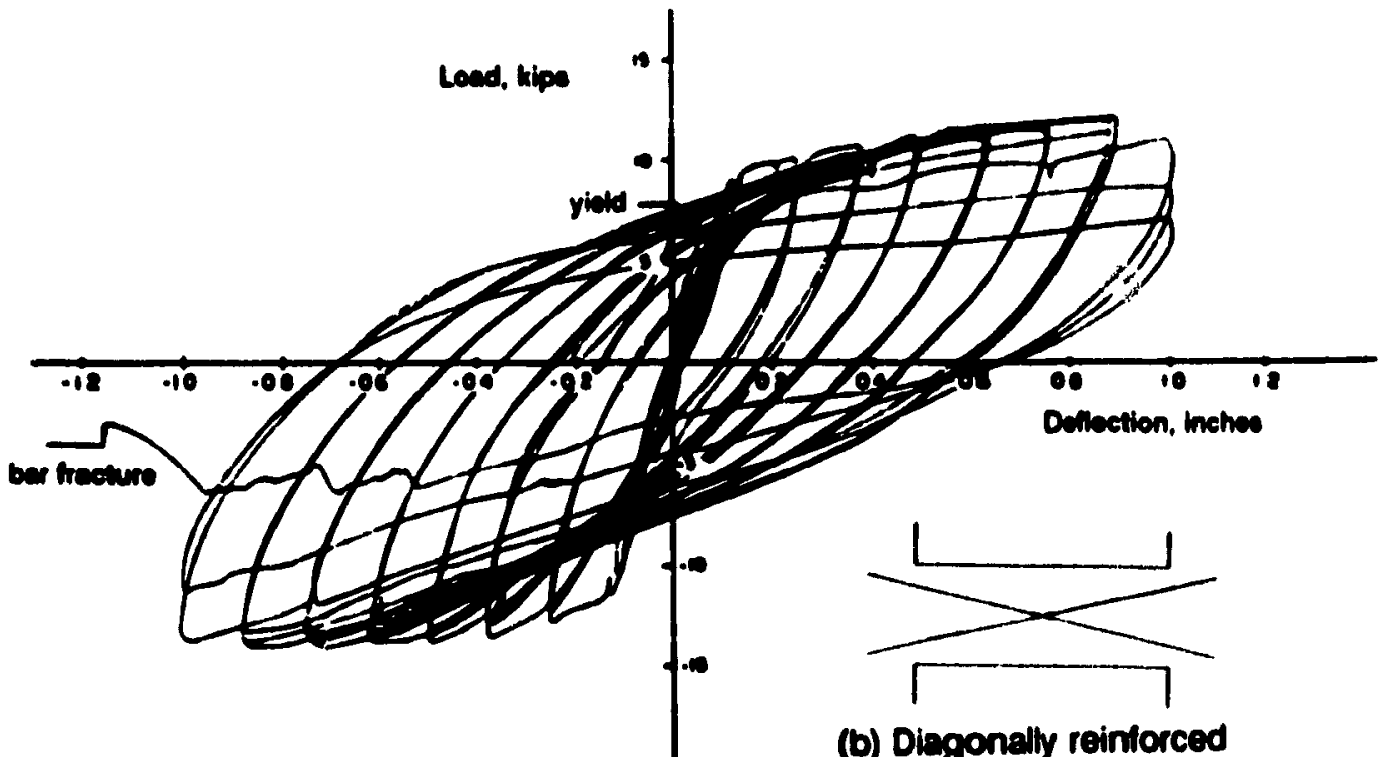

Fioure 1.4 Load versus deflection response for comventionally reinforced (top) and diagonaly reinforced (bothom) coupling beams with span-to-depth retios of 2.5 from Shiu. or al, 1978) 
concrete coupling beams conteining structural steel members. It is interesting to note that many older reinforced concrete coupled wall systems heve steet members encased in the coupling beams. These steel members ofien senved es erection steel and were not ypically accoumed for in design.

Paparoni (1972) reported on a study of a reintorced concrete coupling beem conteining en encased anctural ip section tested at the Leboretorio Nacionel de Engentheria Civil in Lubon. This study imvestigated the reveread cyclic loading response of a $130 \mathrm{~mm}$ wide by $230 \mathrm{~mm}$ deep reinforcad concrete coupling beam spanning $450 \mathrm{~mm}$ conteining conventional bongitudinal end transverse reinforcement and a $140 \mathrm{~mm}$ deep structural $\uparrow$ section. The test epecimen was a model of coupling beams in the Parque Central buildings in Caracas Venezuela. The testing programme also investigated the reversed cyclic loading response of coupling beams reintorced whit a combination of longitudinal and inclined reinforcing bars together with closed stimups. The detaits of the special helined reinforcement for these coupling beams, having a spentlo-dopth ratio of 2, were different then those suggested by Pactey. The results of these teats sugcested that reinforced coupling beams having encased stustural steel members and those reintorced with the special inclined reinforcernent extibited ductilities and eneroy absorption characteristics between those of conventionely reinforced and diegonelly reinforced coupling beems.

Research conducted at McCin University by Mikchell and Cook (1889) inveatlgated the reversed cyclic loading response of a reinforced concrete coupling beam containing a structurel steel channel. The encased channel is rapresentetwe of erection steel uaed in some older structures. The $280 \mathrm{~mm}$ wide by $610 \mathrm{~mm}$ deep coupling beam spanning $1525 \mathrm{~mm}$ contained longhudinal reinforcing bars and clocety spaced closed atimps as well as a $150 \mathrm{~mm}$ doep structural channet. The recuhs of this teat showed some improvement in ductilly and hyateretic behaviour over conventionally reinforced link beams.

Another research programme which involved composite link beams was carried out at the University of Dundee by Subedi (1989). This programme imolved replacing conventional shear reinforcement with encased steel plates. The results from this prefiminary testing programme indicated that premature shear faiture may resull If the plate has inedequete anchorage to the concrete. Several different methods were inveatgated in an attempt to provide horizontal shear resistance between the encased steel plate and the longltudinal reinforcing bers. The specimens of this test series were subjected to monctonic loading onty and $k$ b doubtul th the details proposed would perform well under reversed cyclic loading. 


\subsubsection{Embodded Connectlons of Struetural Steel Membere In Relmforeed Conerete}

Structural steel members with their ends embedded in concrete, serving as haunches or brackets, have been used to provide connections for many years in precast and cast-in-place construction. Marcakis and Mitchell (1980) imestigated the response of different types of structural steel members embedded in reinforced concrete and proposed a design procedure for determining the embedment strength of such connections. This approach forms the basis of current design recommendations for these type of connections (PCl, 1985 and CPCl, 1987). The tests demonstrated that the embedded connection can be designed to develop the full capacily of the embedded structural steel member.

\subsection{Objectives of Research Programme}

Several researchers have investigated novel approaches for improving the ductilin and energy absorption of reinforced concrete coupling beams. For span-to-depth retios lose than about 2, specially detailed diagonal reinforcement (e.9. Paulay and Binnoy, 1974) has been shown to significantly improve the reversed cyclic loading response. Structurel ateel members, fully encased in reinforced concrete coupling beams (e.g., Paparoni, 1972 and Mikchell and Cook, 1889) have resulted in slightly improved responses over conventionally reinforced coupling beams. The objective of this research programme is to imvestigate the feasibility of using structurel steel members, having their ends embedded in the walls, 10 replace reinforced concrete coupling beams.

The use of steel coupling beams to connect reinforced concrete walls has the following polential advantages:

i. Property designed and detailed steel coupling beams can exhibit excellent ductility and energy absorption.

i1. The prelabrication of steel coupling beams provides improved quality control and eliminates a considerable amoum of on-site labour.

iii. Formwork can be significantly simplified.

The specific objectives of this research programme are:

I. To test full-scale specimens under reversed cyclic loading to determine the hystereic responas of structurel steel link beams having their ends embedded in reinforced concrete walls.

ii. To attempt to achieve a reversed cyclic loading response similer to that exhibited by ateel link beams in eccentrically braced frames. 
iii. To investigate factors influencing the reversed cyclic loading response of the link beam over its clear span and along its embedments.

iv. To investigate factors influencing the reversed cyclic loading response of the reinforced concrete embedment regions.

v. To develop design and detailing guidelines to enable large ductilities and energy absorbing capabilties to be achieved in steel link beams used to couple reinforced concrete hexural walls. 


\section{Chapter 2 \\ Prototype Structure}

\subsection{Introduction}

The analysis of the prototype structure was carried out using the 1990 National Building Code of Canada (NBCC) to determine the lateral design forces. In order to achieve the desired ductility, the steel link beam was designed in accordance with Clause 27, Seismic Design Requirements, and Appendix D, Seismic Design Requirements for Eccentrically Braced Frames, of CAN/CSA S16.1-M89. Design of the ductile concrete walls was in accordance with Clause 21, Special Provisions for Seismic Design, of CAN/CSA A23.3-M84. The reinforced concrete region surrounding the link beam embedment had to be carefully designed and detalled so that the desired level of ductility could be achieved in the link bean.

\subsection{Prototype Structure}

The prototype structure is a twelve storey reinforced concrete flat plate structure having a centrally located core. The structure, shown in Fig. 2.1, consists of $5.6 \mathrm{~m}$ bays in the North. South direction and $7.6 \mathrm{~m}$ bays in the East-West direction. There is a $1.5 \mathrm{~m}$ cantilever slab around the periphery of the structure. The storey heights are $3.65 \mathrm{~m}$ except the first storey which has a height of $4.85 \mathrm{~m}$. The structure has $600 \mathrm{~mm}$ square columns supporting a $200 \mathrm{~mm}$ flat plate floor slab system.

The elevator core is $6 \mathrm{~m}$ by $9 \mathrm{~m}$ and is designed as a ductile flexural wall in both directions. The walls are $300 \mathrm{~mm}$ thick. The $9 \mathrm{~m}$ long East-West walls are a coupled system consisting of two $3.9 \mathrm{~m}$ walls linked by a $1.2 \mathrm{~m}$ long coupling beam located at each floor level. The $6 \mathrm{~m}$ long East-West walls are flexural walls without openings.

The prototype structure is located in Vancouver. The core was designed as ductile flexural walls to carry 100 percent of the lateral loads in each principal direction. The corresponding seismic force modification factor, $R$, is 3.5 (NBCC 1990). 


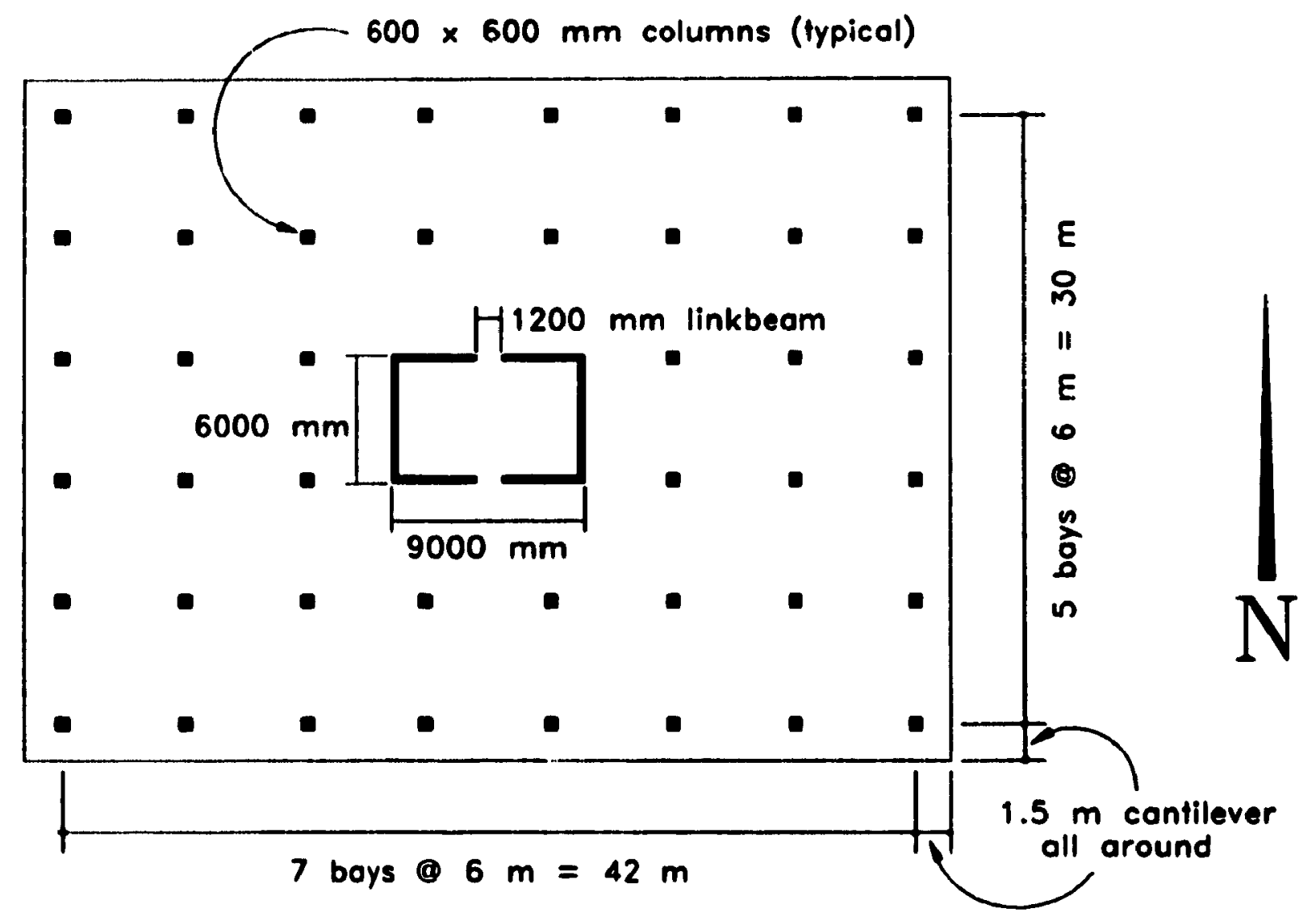

Figure 2.1 Protoype etinuture

\subsubsection{Material Propertice}

The following specifled velues were used for the design of this structure:

Concrete: normal dencity concrete with $\mathrm{f}_{\mathrm{c}}^{\prime}=35 \mathrm{MPa}$

Reintorcing Steet: $I_{y}=400 \mathrm{MPa}$

Link bean Steol: $F_{y}=300 \mathrm{MPa}$ 


\section{2 .2 Leading on Strueture}

The following Netionel Bullding Cods of Censda (NBCC) loading criteria were used in the anclysis of the sincture:

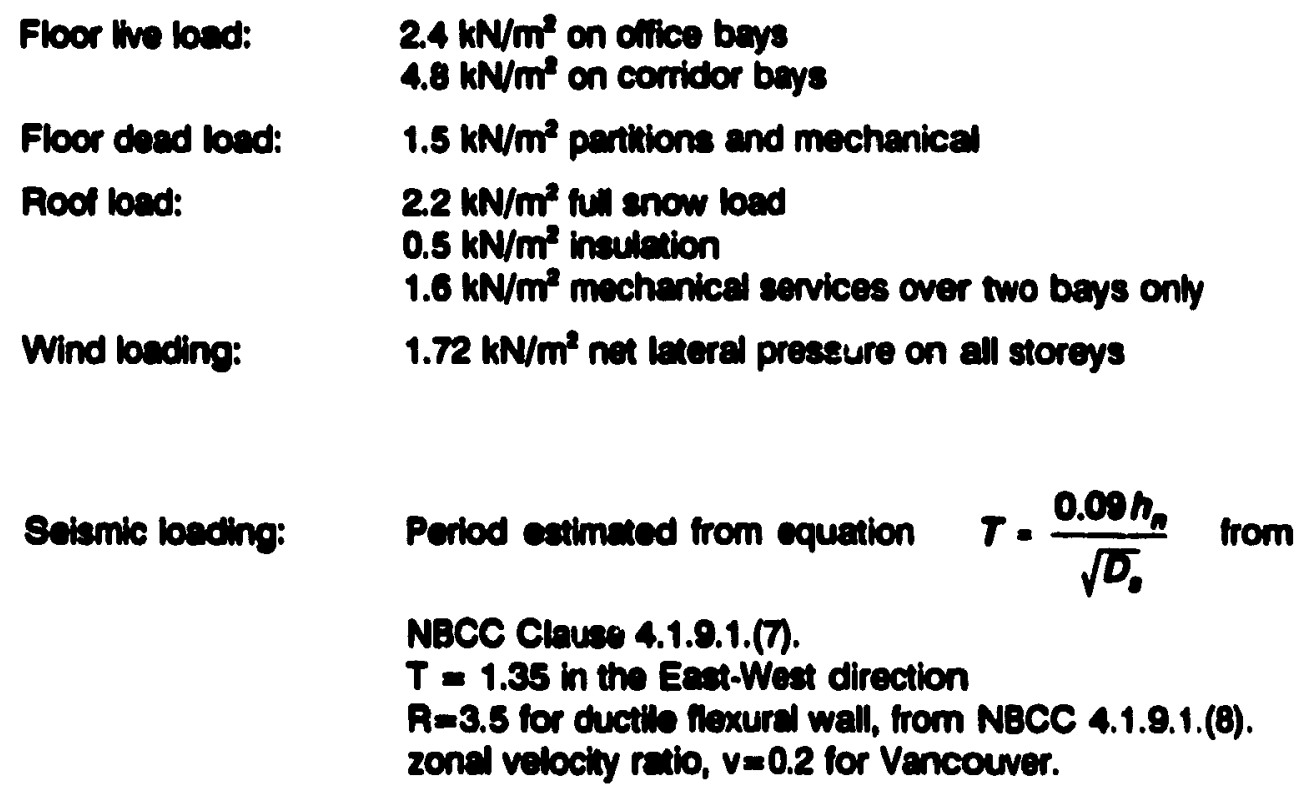

The base shear due to selemic loading, defined by NBCC Clauses 4.1.9.1.(4) and (5), was $5829 \mathrm{kN}$ in the East-Weat direction. The concentreacd load at the top of the structure, defined by Cleuse 4.1.9.1.(13)(0), Fw wes 551 kN. The remeining selanic lateral load was distributed over the haight of the structure in sccordance with the formula given in Clause 4.1.9.1.(13)(a).

The fectored base shoer due to lexerel wind load, determined according to NBCC Clause 4.1.8.1, was found to be $3483 \mathrm{kN}$ in the East-Weat direction and $4876 \mathrm{kN}$ in the North-South direction, represented by uniformly distributed lateral loads of 77.4 and $108.4 \mathrm{kN}$ per metre of height, respectively. All lateral loads were considared to be resisted by the core alone. The coupled well system in the Eaxt-Weat direction was modelled as two C-shaped walls interconnected by coupling beams (see Fig. 2.1). Table 2.1 summartses the values of the factored deaign shears in the link beams obtained from the equivalent lanina enebyses. The storey drifts from seitumic losds given in Table 2.1, have been muliplied by $A$ in order to account for the indeatic deformations. In the preliminay desion torsional efrects were neglected. Figure 2.2 Mustreses the values for the shose forces in the coupling beams for both the cquivelent lamina and the equivalient frame andyses. As can be seen, the shapes of the distributions of shears in the beems are similer, wht the equivelent freme method giving lower shoers noer the base of the ancture. 


\begin{tabular}{|c|c|c|c|c|c|c|}
\hline \multirow[b]{2}{*}{ Storey } & \multicolumn{3}{|c|}{ NBCC Soismic Losding Conditions } & \multicolumn{3}{|c|}{ NBCC Wind Loading Condkions } \\
\hline & $\begin{array}{c}\text { Link bean } \\
\text { Shear } \\
\text { (KN) }\end{array}$ & $\begin{array}{c}\text { Horizontel } \\
\text { Deflection } \\
(\mathrm{mm})\end{array}$ & $\begin{array}{c}\text { Storey } \\
\text { Drit x R } \\
(\mathrm{mm})\end{array}$ & $\begin{array}{c}\text { Link beam } \\
\text { Shoar } \\
\text { (KN) }\end{array}$ & $\begin{array}{c}\text { Horizontel } \\
\text { Deflaction } \\
\text { (mm) }\end{array}$ & $\begin{array}{c}\text { Storey } \\
\text { Drift } \\
\text { (mm) }\end{array}$ \\
\hline 12 & 125 & 263 & & 99 & 48 & \\
\hline 11 & 251 & 243 & 70 & 101 & 40 & 5.7 \\
\hline 10 & 254 & 223 & 71 & 108 & 35 & 5.6 \\
\hline 9 & 258 & 202 & 72 & 111 & 29 & 5.5 \\
\hline 8 & 259 & 181 & 73 & 116 & 24 & 5.4 \\
\hline 7 & 258 & 160 & 75 & 120 & 19 & 5.2 \\
\hline 6 & 251 & 138 & 78 & 124 & 14 & 5.0 \\
\hline 5 & 237 & 116 & 77 & 128 & 9 & 4.6 \\
\hline 4 & 216 & 93 & 78 & 125 & 5 & 4.1 \\
\hline 3 & 186 & 71 & 78 & 121 & 2 & 3.3 \\
\hline 2 & 145 & 49 & $\pi$ & 112 & -1 & 2.3 \\
\hline 1 & 82 & 27 & 75 & 89 & -2 & 0.9 \\
\hline ground & & 0 & 85 & & 0 & -1.6 \\
\hline
\end{tabular}

Table 2.1 Summary of link beam shears and horizontal well deflections from preliminary analyses 


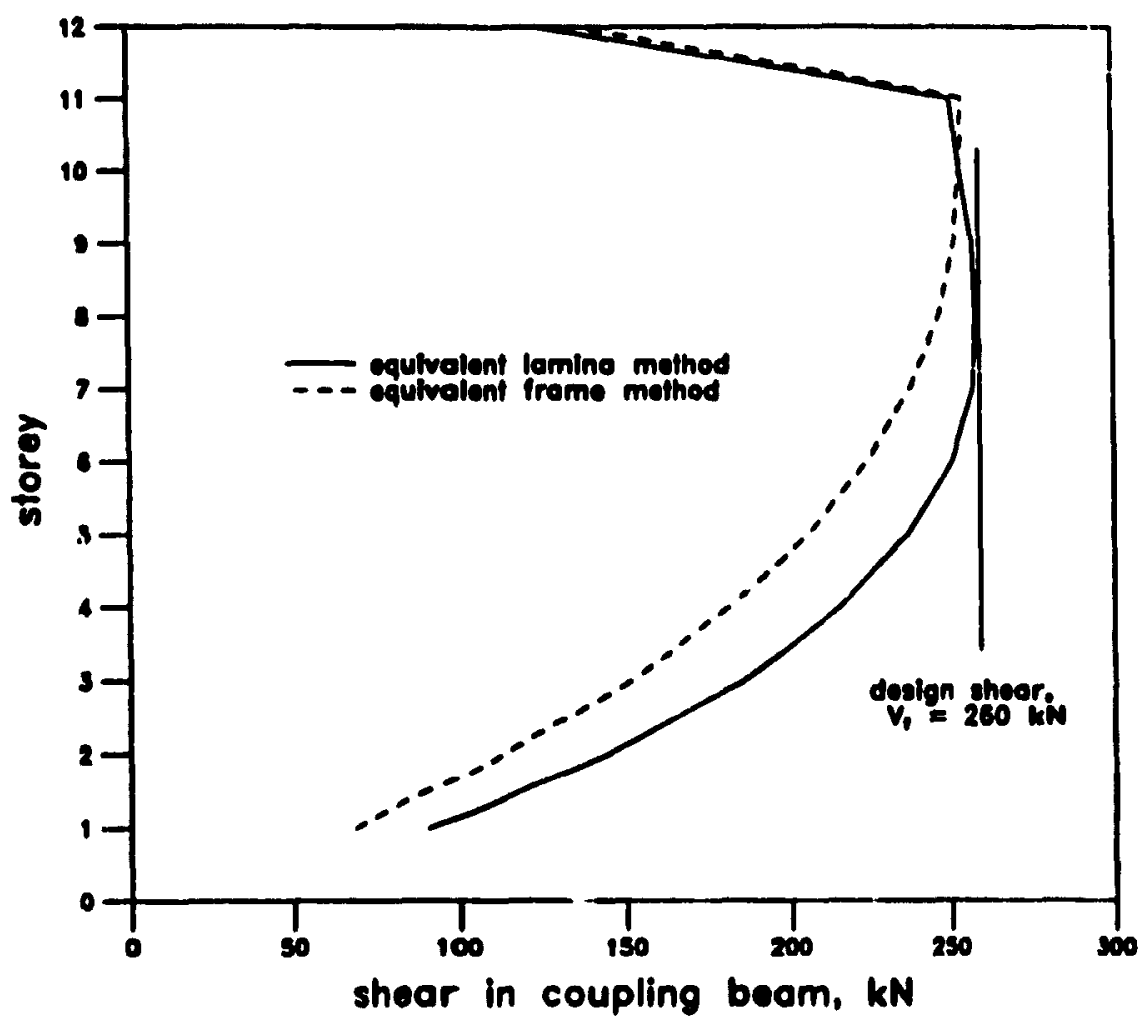

Figure 2.2 sherse in coupling beams determined from equivelent lomina and equivelent freme enclysees 


\section{Chapter 3 \\ Specimen Dealgn and Detalling}

\subsection{Dosign of the Stool Link Boam and Embedmomt Roglon}

\subsubsection{Deofirn of the Exposed Span of the Link Dean}

The steel link beam was decigned in accordence with CAN/CSA S16.1-M89 Clouse 27, Seismic Deaign Requirements. Appendix D, Seiemic Dedign Requirements for Eccentrically Braced Frames, provides design and detailing requirements for link baams in eccentrically braced frames, the principles of which are directly applicable to the dealgn of a ductile seel coupling beam.

Since the coupling beam in a ductib coupled wall system to the criced element, in must respond in a ductile manner and exhibit significant energy cteorbing characteristics. Unlike reinforced concrete coupling beams, which are deaigned to avold shear fallures and to develop flexural hinges, steel coupling beams are more ductle and are able to disslpate significantly larger amounts of energy if they are designed and detalled to ylald in shear. Since the shear-to-moment ratio is large in typical short-span link beams, this "shear crikeat dasign crterion is anainable.

In design of such a link bean, the primeny requirement is to enaure that the ultimate shear capacity of the link bean will be reached while the boan remains elastic in flexure. This requirement will ensure that the maximum amount of energy will be disaipated when tho link beam begins to exhibit platic behaviour.

The steps for designing and detailing the cxposed portion of the link beam are as follows:

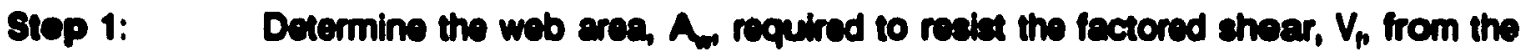
following exprescion used for plactic dasion for the factored chear resistance, $V_{f}$ :

$$
V_{p}=0.65 A_{w} F_{y}
$$

where: $\quad F_{y}=$ specilised minimum yiskd stress. 
Stop 2:

Choose the heigh, $h$, and the width, $w$, of the web to give the requited $A_{\text {, and }}$ to satisty the following limits for a Class 1 section in order 10 avoid local buckling of the web:

$$
\frac{n}{w} \leq \frac{1100}{\sqrt{F}}
$$

Step 3: Determine the required section modulus, Z, such that the section has a moment resistance, $M_{n}$ greater than or equal to the moment corresponding to the development of strain hardening in shear:

$$
Z=\frac{M}{\Delta F_{y}}
$$

where:

$$
M=\frac{L}{2} \times 1.27 V_{r} \text {. }
$$

$L=$ the clear epen of the link bean,

$\phi=$ material resistance factor, typically taken as 0.90 , and

the factor 1.27 accounts for the development of strain hardening.

Stop 4: In choosing a section to give the required $Z$, the contribution of the web should be lonored since if will be yielding in shear. Choose the flange dimensions such than the wioth of the flange, $b$, and the thickneas of the flange, $t$, satisty the limits for a Class 1 section, in order to avoid local buckling of the liange:

$$
\frac{b}{2 t} \leq \frac{145}{\sqrt{F}}
$$

Step 8: In order to control out of plane buckling, the maximum unsupported length of the link bean, hen is given as:

$$
L_{0}=\frac{\sec r_{x}}{\sqrt{F_{y}}}
$$

where: $\quad r_{1}=$ the radius of gyration of the section.

8tep 8: Provide full depth stilieners at the faces of the concrete walls. These stiteners muat have a combined width of at baat b - 2w, enthough providing stilieners wide enough to be flush whin the link bean flange tips would simplity the formwork details. The stifieners must have a thickneas no less than $0.75 \mathrm{w}$ nor $10 \mathrm{~mm}$.

Stop 7: $\quad$ Provide full depth intermediate stifeners at a spacing no greater than $38 w-0.2 d$. If the depth of the link beam is less than $650 \mathrm{~mm}$, imermediate stilleners may be placed on only one side of the web. In this case the with of the stifieners must be greater than 0.56 - W and the thickness must be greater than $10 \mathrm{~mm}$. If 
stilieners are provided on both sides of the web, the limits given in step 6 for with and thickness apply.

Step 8: Design the fillet welds connecting the stifieners (Area $=\mathcal{A}$ ) to the link beam wob in order 10 develop a stimener force of A,F. The fillet weld connecting the stifiener to the link bean flanges must be designed to develop a stitener force of $0.25 \mathrm{AF}_{\boldsymbol{v}}$.

Stop 0: If the beam is a built-up section, the design of the flange-lo-web welds must be carried out in accordance wih Clause 13.13.

Since the design of a ductile coupled well system is based on capacily dusign principles, in must be recognised that any excess strength provided in the link beams will require additional resistances throughout the corcrete walls in order to achieve the desired hierarchy of yielding.

\subsubsection{Dealgn of the Rolmforced Concrete Embedmemt Reglon}

Since the link beam is required to undergo significent inelastic deformation lis embedment must be capable of developing the capacky of the link beam.

The design of the concrete embedment of the link beam is modelled atter the doeign of steel haunches in concrete members developed by Marcakis and Minchell (1980) and recommended by the design handbooks of the Prestressed Concrete Insthute (1985) end the Canadian Prestressed Concrete Insthute (1987). This approsch assumes rigid body rotation of the embedded section in calculating the applied concrete stresses over the length of the embedment. Figure 3.1 mustrates the assumed strain distributions and the equivalent rectengular stress blocks over the embedment length.

The steps for designing the embedment of the link beam are summarised as follows:

Step 10: Determine the effective width, b', of the concrete compreseion block. This width is defined as the width of the confined wall region measured to the outaide of the confinement ateel but should not exceed 2.5 times the bearing widh, b. (see Figure 3.1)

Step 11: Determine the required length of embedment, $L$, such thet the factored sheer resiatance, $V_{e}$ of the embedment b oreater then the shoer cepectly of the exposed link beem, including the efiects of atrain herdening. This shear cepectiy is teken 281.27 . Hence, the minimum value of $L_{0}$ can be determined from the following relationship: 
Loading Conditions

Strain Distribution

Assumed Stress Distribution
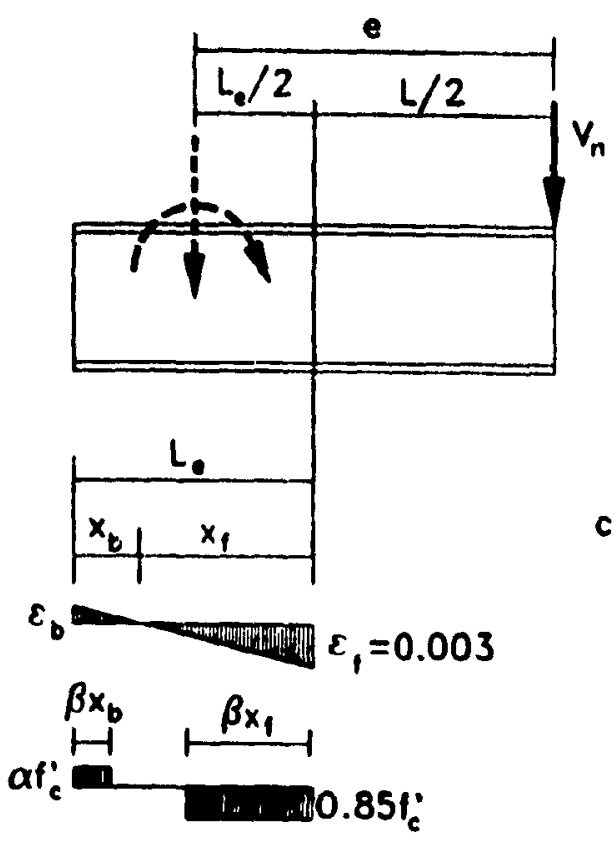

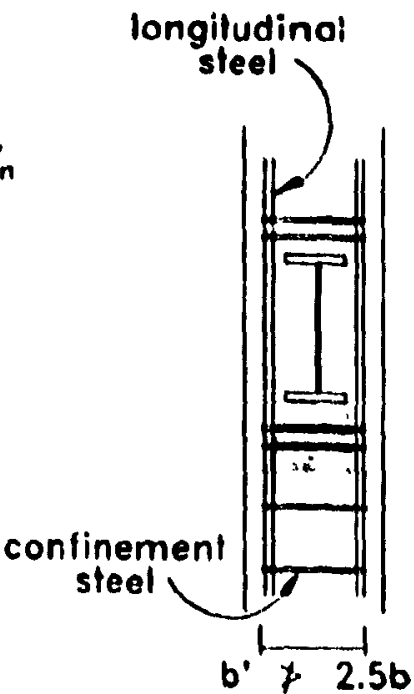

width of flange $=b$

Floure 3.1 Assumed strain and stress distribution over the embedment (edepted trom Marcakis and Minchen, 1980)

$$
1.27 V_{p} s V_{c}=\frac{0.86 Q_{0} f_{0}^{\prime} b^{\prime} L_{0}}{1+\frac{3.60}{L_{0}}}
$$

where: $\quad \theta=$ the eccentricity of resuliant shear loads from the centre of the embedment (1.0., $\left.-=\frac{L}{2}+\frac{L_{0}}{2}\right)$, and

$r_{c}=$ the compressive strength of concrete.

thus the minimum length of embedment is found from the quadratic solution to Equation 3.6 as:

$$
L_{0}=\frac{1}{2}\left[\frac{3.86 V_{c}}{0.85 f_{0}^{\prime} b^{\prime}}+\sqrt{\left(\frac{3.63 V_{c}}{0.85 f_{0}^{\prime} b^{\prime}}\right)^{2}+\frac{0.14 V_{,} L}{0.85 f_{b}^{\prime} b^{\prime}}}\right]
$$


The design procedure for embedments described sbove was developed for monctonic loading. For reversed cyclic loading additionsl deaign considerations are required. Upon revered of the looding the gap created at the link basm fiange-concteto interface will firt have to be closed belore significant reaktence can be resticed. If the gap becomes too lerge upon cycling then en undesirable hystereats reaponse of the connection region will reach. In order to control the gap. II is necesseny to provide sufficient verticel reinforcing bere crosing the link besmconcrete interfece (see fig 3.2). The enount of steel required can be determined as follows:

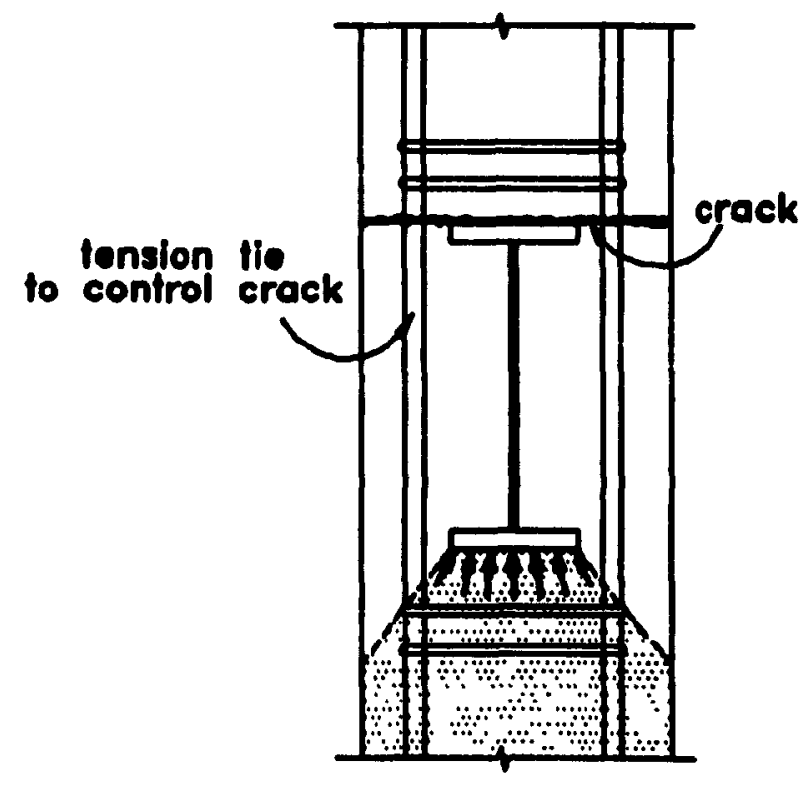

Figure 3.2 Roinforcing steel requirement acrose the fiange-concrete interteces

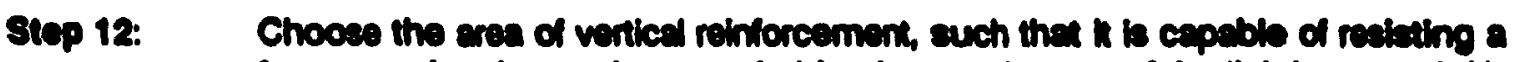

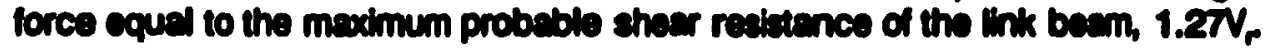
Thus the serea of steel required is:

$$
A_{c}=\frac{1.27 V_{p}}{f_{y}}
$$

The steel required to develop this force must be arranged over the embedment length of the link bean.

The steel requirement calculased in this stop is a minimum area requirement and nead not be in addition to the concentrated flexural reinforcement of the wall. It is importent, however, to ensure that the gap controing steel ls located close to the frce of the wall. In this case in will 
be most economical to limit the region of concentrated reintorcemem to a length no gremer than that of the embedment.

The link beems were designed for the protosype stucture, given in Chapter 2, uaing an applied factored shear, $V_{n}$ equal to $240 \mathrm{kN}$. In spplying the procedures cascribed above for the design of the test specimen, the material realatance factors, $\phi_{,} \phi_{c}$ and $\phi_{c o}$ were taken as 1.0. The complete design and detalling of the link beam, Specimen 1, using specified material propenties, are given in Appendix $A$.

\subsubsection{Deceription of Epecimen 1}

Figure 3.3(a) ahows the dotels of the link beam deaign for spocimen 1. The link beem has a clear spen of $1200 \mathrm{~mm}$ and en embedment length, at each end, of $600 \mathrm{~mm}$, bringing the totel length of the bean to $2400 \mathrm{~mm}$. The bean wes decigned 23 a buil.up section with a $3 / 4$ inch $(19.2 \mathrm{~mm}$ ) flange and a $3 / 16$ inch $(5 \mathrm{~mm})$ web. The overall height of the section was $350 \mathrm{~mm}$. The section was designed following the procedure described in Section 3.1.1, so that the untimate shear capacily could be developed white the ecction remained elastic in flexure. Full-depth, $10 \mathrm{~mm}$ thick stifieners having a spacing of $120 \mathrm{~mm}$, were provided on one side of the wob slong the clear span. As well as inthibiting web buckling, these stifeners delay flange buckling. Stifieners on both sides of the web were provided at each end of the clear span. No stifieners were loceted along the embedment lengths. The decign of Specimen 1, using the measured material properties and dimensions, is given in Appendix $A$.

\subsubsection{Pefinemente to the Desion Procedure for spocimen 2}

The link bean of Specimen 1 undenwent significant inelastic deformations along the

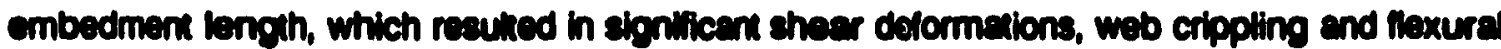
hinging of the link beem slong the embedment (see Chepter 5). Refinements were made to the design procedure of Specimen 2 in order to avoid theae problems. The shear and locel buckling restatances of the link beam web in the embedmonk were increased in order to ensure thet this region remained elastic.

The refinements to the decion procedure given sbove sre ese follows:

Step 8A: In order to ensure that the link bean remain clastic along hs embedment, the embedded region is designed for a factored shear resistance, $V_{n}$ of: 


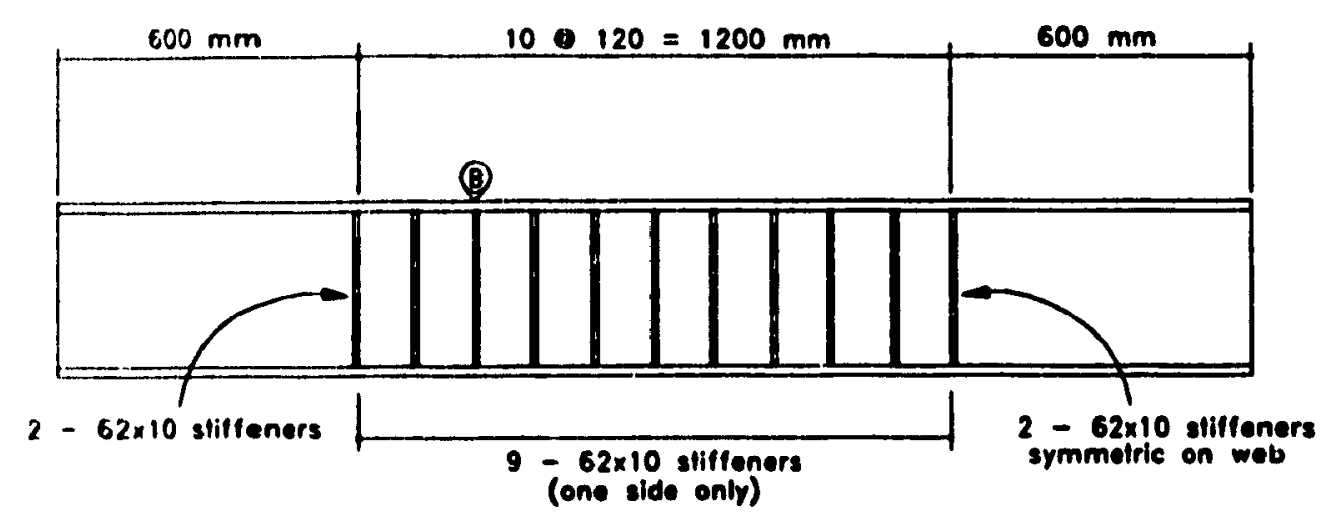

(a) Spocimen 1

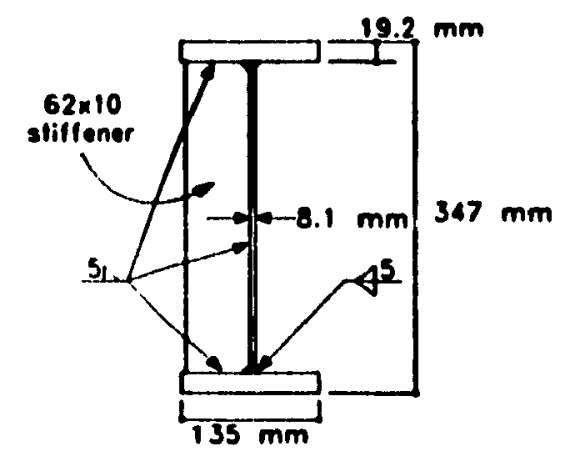

Section A

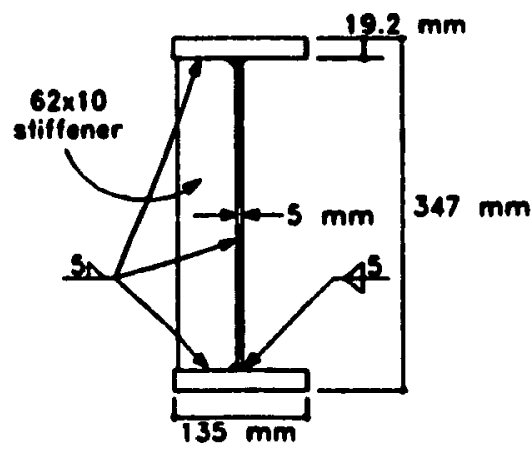

Section 8

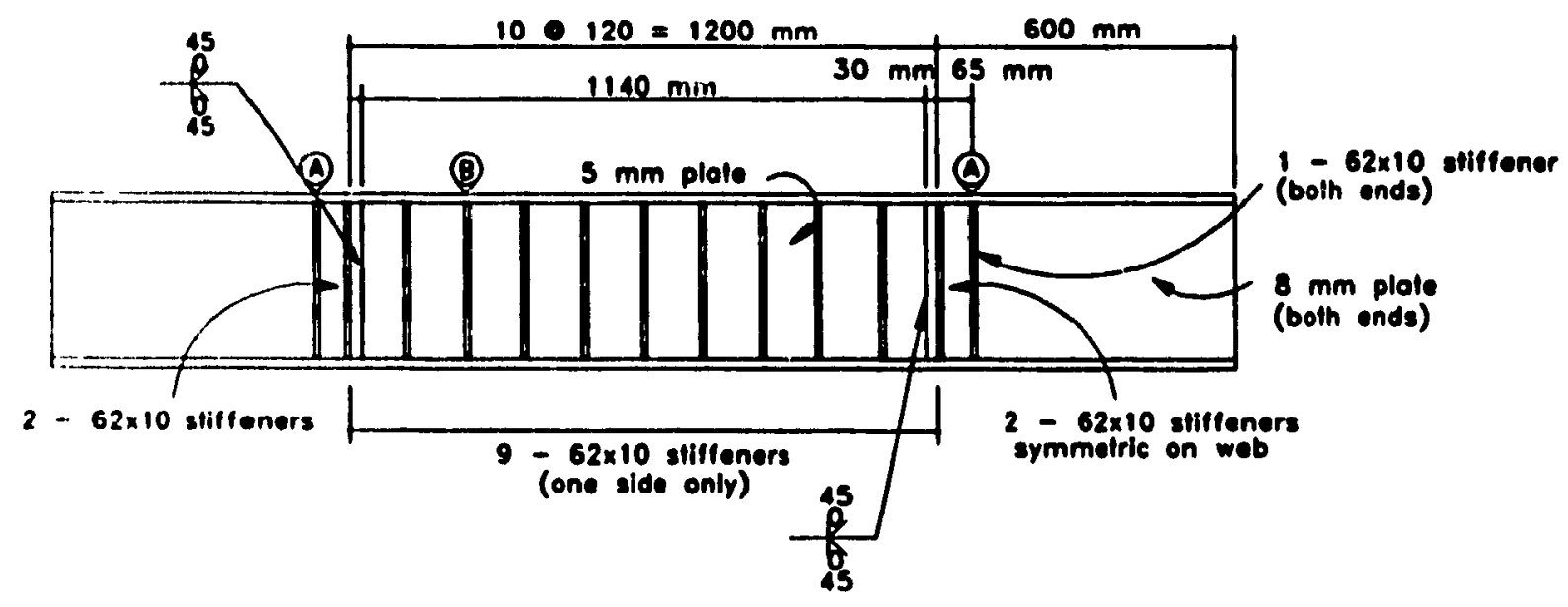

(b) Specimen 2

Figure 3.3 Detells of link beem Specimens 1 and 2 


$$
v_{1}=\frac{M_{p}}{\frac{L}{2}}
$$

thus, the required wob thicknees, 4 , for the embedded region can be found using the Equation 3.1 es:

$$
t_{w}=\frac{v_{c}}{0.65 f_{v}}
$$

Step 7A: Since spelling of the unconfined concrete cover occurs due to reversed cyclic loading, an additionsl intermediate stifiener is provided at a distance equal to the concrete cover from the face of the wall. This additionel stimener, locexed where the compressive streins in the concrete are greatest ather spaling. serves to prevent flange bucking and web crippling.

Step 11: To account for cover speling, the effective length of embedment, Lr. is reduced to the actual embedment length minus the concrete cover, $L$ - c (200 Fig 3.4). Hence, the lever arm, e, measured to the centre of the elfective embedment is

$$
\text { - }=\frac{l}{2}+\frac{4}{2}+c \text {. }
$$

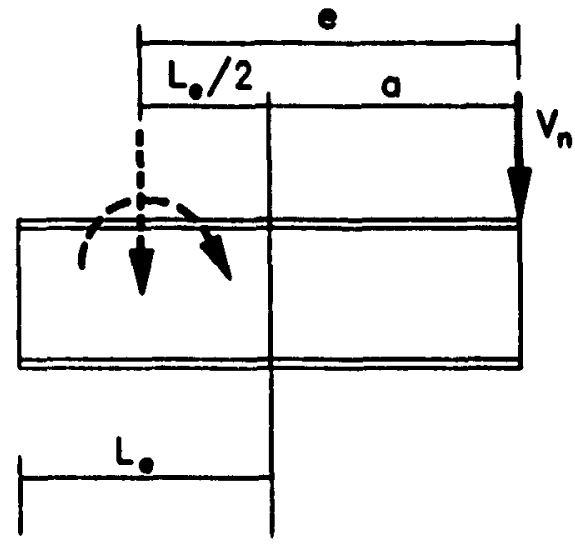

(a) before cover spalling

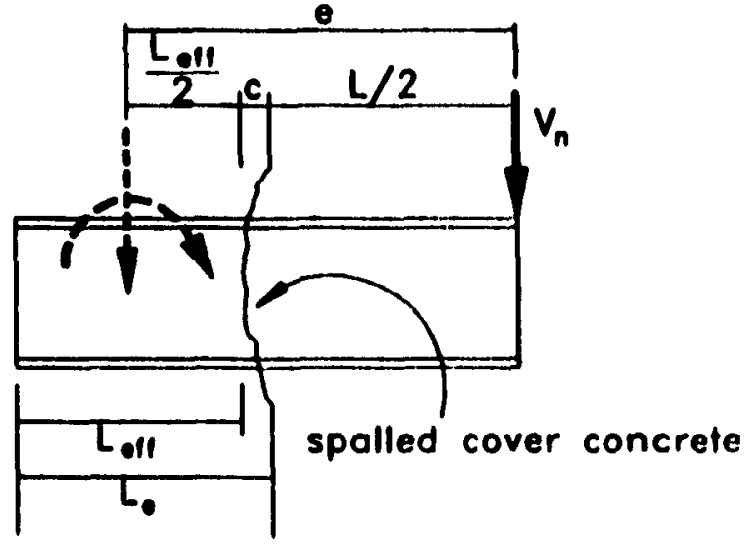

(b) with cover spalling

Floure 3.4 Eliecive length of the embedment

Specimen 2 was designed, including these refinements to the procedure, using the same design shear and material resistance factore es Specimen 1. 


\subsubsection{Deseription of Spereimen 2}

Figure 3.3(b) shows the details of the link beam for Specimen 2. The dimensions of Specimen 2 are identical to those of Specimen 1. The only change in the design of the link beam cross section is that the wob of the beam in the joint region was increased to $5 / 16^{\circ}(8 \mathrm{~mm})$ thick. This change ensures that the embedded region of the link beam will remain elastic when the shear capacity of the $3 / 16^{\circ}(5 \mathrm{~mm})$ thick wob in the clear span is developed. The stifiening details in the clear span are identical to those of Specimen 1. An additional stifiener has been added in the joint region of the link bean, at a distance from the face of the wall of $65 \mathrm{~mm}$, corresponding to the location of the first ventical reinforcing bar (see Figure 3.5). This stiliener was added in order to ensure that there is no web crippling in the joint region atter the cover concrete has spalled.

\subsection{Dealgn of the Walls}

The walls for Specimens 1 and 2 are identical and are shown in Fig. 3.5. Each wall has 6 No.25 ventical bars arranged over the embedment length of the link bean. This reinforcement was chosen to provide sufficient tensile capactly over the embedment to equiltbrate the compressive resultant in the embedded region. This load was found to be $1176 \mathrm{kN}$. An additional 2 No.25 bars were located at the back of the wall.

Two No.10 (11.6 mm dia.) horizontal ties were provided at both the top and bottom fiange of the link beam to anchor the compressive struts genereted by the seasumed rigid body rotation of the link beam. The remaining horizomal ties were placed at $260 \mathrm{~mm}$ centres, in accordance with the requirements of CAN/CSA A23.3-M89 Clause 21. Additional ties were located at the top and bottom of the walls to provide confinement in the event the walls rotated on their supporting beams.

Two sets of No.10 vertical bars were also supplied at $300 \mathrm{~mm}$ centres to conform to Clause 21 requirements.

The venical bars were welded directly to the suppon beams in order to ensure the homogeneous movement of the specimen and test frame.

A photograph of the reinforcing cage with the beam in place is shown in Fig. 3.6. 


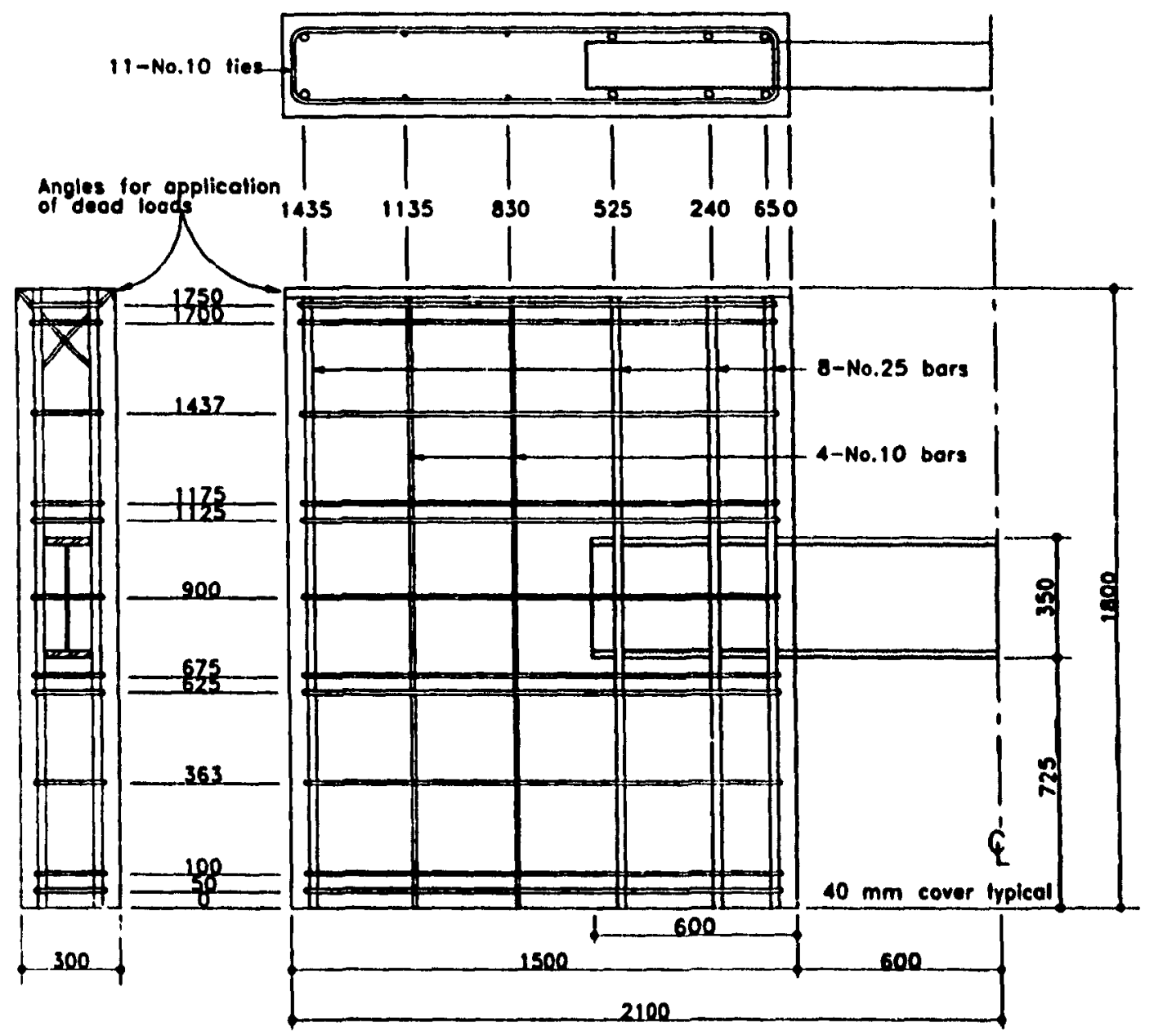

Flgure 3.5 Details of reinforcing cage of both specimens

\subsection{Matorial Propertices}

\subsubsection{Adnoreling stew}

In accordance with Clause 21.2.5.1 of CSA-A23.3-M84, reintorcing bars conforming to CSA standard C30.16-M were used. Tension tests were pertormed on $300 \mathrm{~mm}$ lengths of each bar size. The applied load and the extension over a $50 \mathrm{~mm}$ gauge length were recorded up to the onset of strain hardening. The results of the tension tests are reported in Table 3.1. The reifforcing steel from the same heat was used for both specimens. 


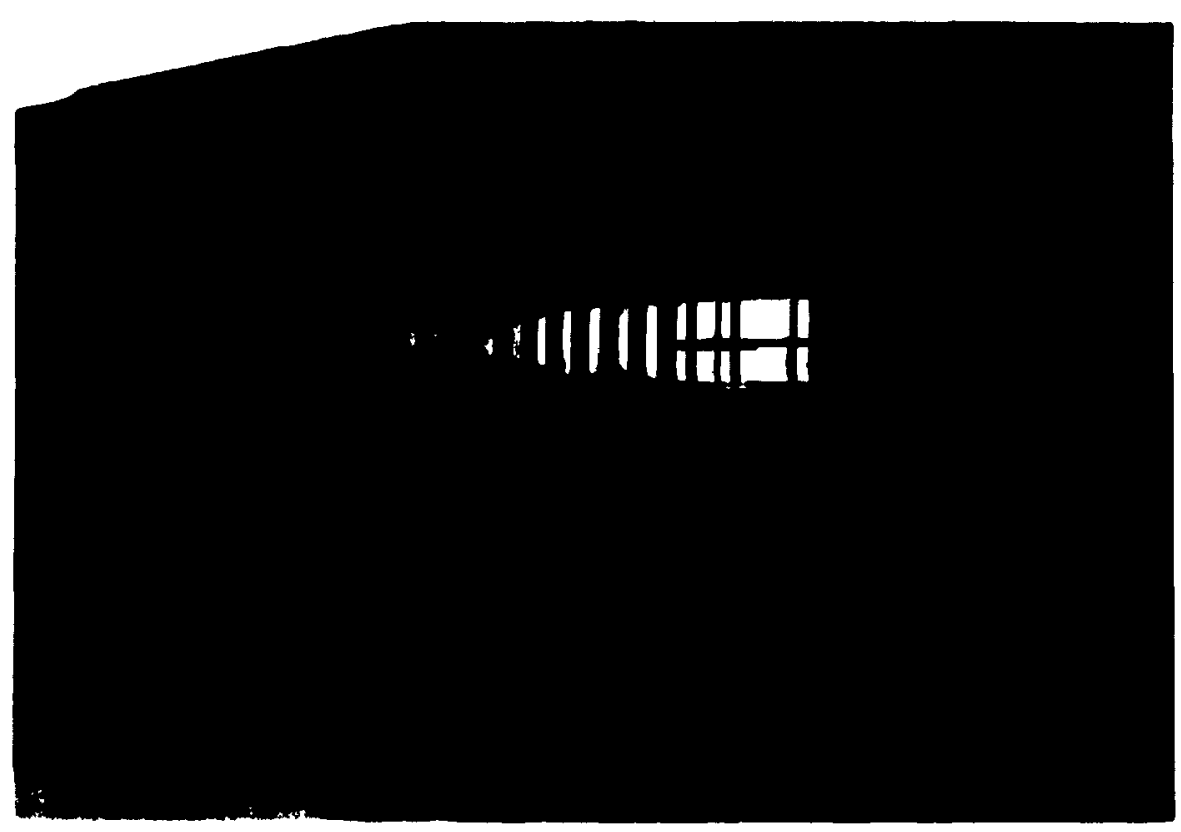

Fiprere 3.6 reintoraing eage end link bean of Epecimen 1

\begin{tabular}{|c|c|c|c|}
\hline Ber alno & Viald eneses & Unimete Eineses & Eencmion a \\
\hline No.10 & $458 \mathrm{MPa}$ & $740 \mathrm{MPa}$ & 10 \\
\hline No.25 & $410 \mathrm{MPa}$ & הקM 678 & 14 \\
\hline
\end{tabular}

Teles 3.1 Properies of reinforeing exed

\subsubsection{Cenerento}

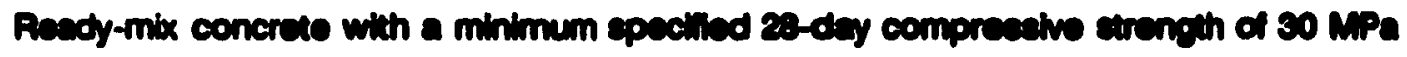
and a spectiled stump of $150 \mathrm{~mm}$, whe used in the frbriention of the wall in order to harease

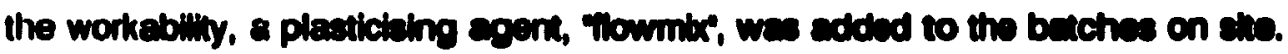

A number of $150 \times 300 \mathrm{~mm}$ cylindere and $180 \times 180 \times 600 \mathrm{~mm}$ fiexural beams were prepared from eech concrete betch. Compreveion end epuiting tects were pertormed in order to

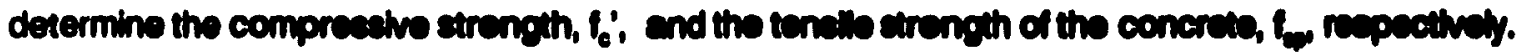

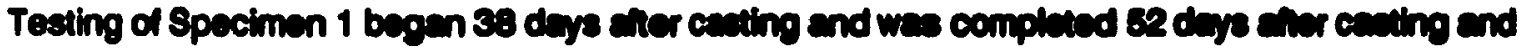

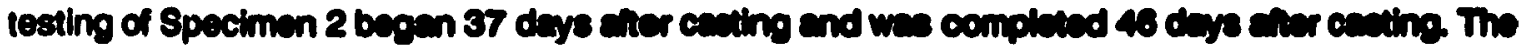
concrete materiel propentias and the eges at which they were determined are reported in Tables.2. 


\begin{tabular}{|c|c|c|c|}
\hline $\begin{array}{l}\text { Concrete from } \\
\text { Specimen Number }\end{array}$ & $\begin{array}{l}\text { Comprescive } \\
\text { Strength }\end{array}$ & $\begin{array}{l}\text { Tenalle } \\
\text { Strengith }\end{array}$ & $\begin{array}{l}\text { Modulus of } \\
\text { Elanticiny }\end{array}$ \\
\hline 1 & $\begin{array}{l}25.9 \mathrm{MPa} \\
\text { (at } 43 \text { doys) }\end{array}$ & $\begin{array}{l}1.74 \mathrm{MPa} \\
\text { (at } 45 \text { doya) }\end{array}$ & $24875 \mathrm{MPa}$ \\
\hline 2 & $\begin{array}{l}43.1 \mathrm{MPa} \\
\text { (a } 42 \mathrm{deys})\end{array}$ & $\begin{array}{l}3.84 \mathrm{MPa} \\
\text { (in } 39 \mathrm{dxy})\end{array}$ & $30448 \mathrm{MPa}$ \\
\hline
\end{tabular}

Table 3.2 Properties of concrete

Figure 3.7 Illustrates the representative streas-strain retationahips determined for the concrete used in each specimen.

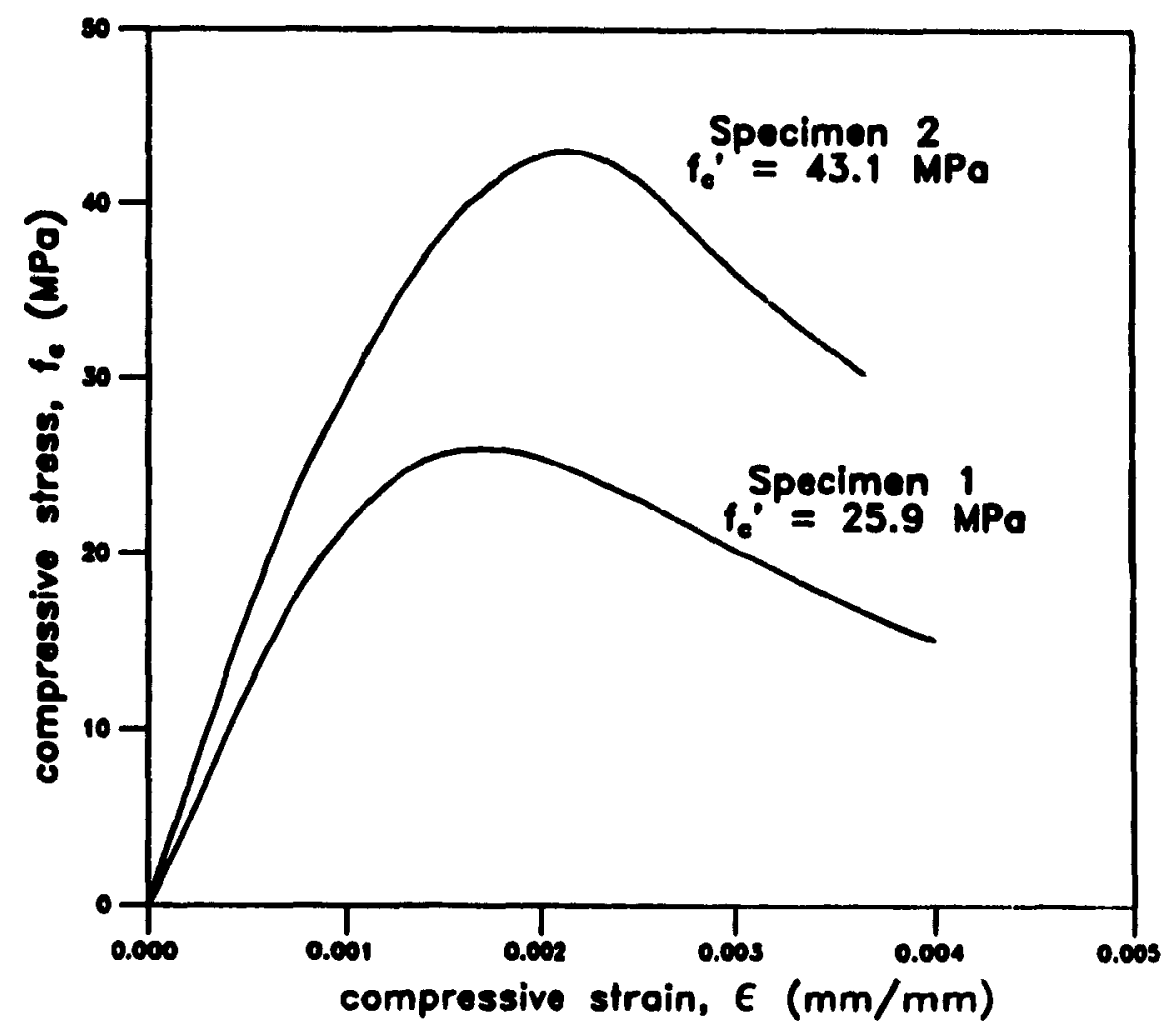

Floure 3.7 Stress-atrain reletionship for concrete used in Specimens 1 and 2

\subsubsection{Link Beam 8ted}

The link beams were fabricated from Grade soow material conforming to CSA Standard C40.21 (CSA, 1985). Tension tests were performed on three coupons cur from each samplo 
provided for the web and flange material. The tension teats were carried out according to the procedure defined in ASTM Standard E8-85a (ASTM, 1985). Applied loed and extenaion over a $50 \mathrm{~mm}$ gauge length were recorded up to the onsel of strain hardening, utimuse load and extensions were also noted. Yiold was determined using the offset method with a yield strein of 0.2\%. The results of the tension tests are reported in Table 3.3. The $10 \mathrm{~mm}$ stock from which the stifieners were fabricated was not lested. Figure 3.8 illustrates the stress-etrain relutionships for the steel used in the webs of each apecimen.

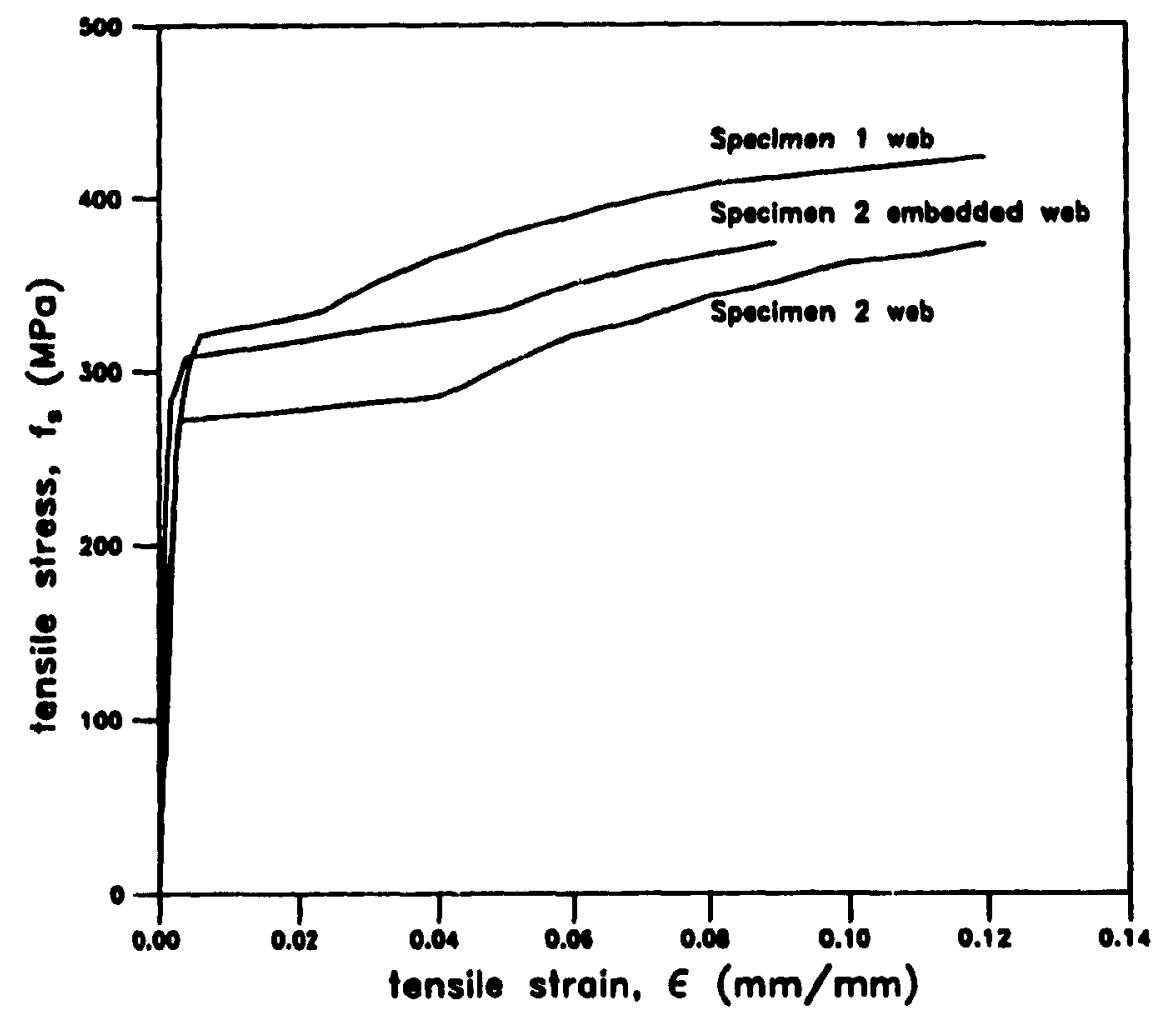

Figure 3.8 Stress-strain relationship for wob eteets used in Specimens 1 and 2 


\begin{tabular}{|c|c|c|c|c|}
\hline Steel Specimen & Yild stress & $\begin{array}{c}\text { Elongation at } \\
\text { onset of etrin } \\
\text { hardening }\end{array}$ & Unimate Streas & $\begin{array}{c}\text { Elongation at } \\
\text { neplume }\end{array}$ \\
\hline Specimen 1 Wob & $320 \mathrm{MPa}$ & $3.2 \%$ & $468 \mathrm{MPa}$ & 324 \\
\hline Specimen 1 Flange & $372 \mathrm{MPa}$ & 4.48 & SM MPa & $30 \%$ \\
\hline $\begin{array}{c}\text { Spocimen } 2 \text { Beam } \\
\text { Web }\end{array}$ & $309 \mathrm{MPa}$ & $4.0 \%$ & 427 MPa & $37 \%$ \\
\hline $\begin{array}{l}\text { Specimen } 2 \\
\text { Embedded Web }\end{array}$ & $276 \mathrm{MPa}$ & $4.0 \%$ & $42 \mathrm{MPa}$ & $34 \%$ \\
\hline Spectimen 2 Flenge & 295 MPa & $2.4 \%$ & $499 \mathrm{MPa}$ & $39 \%$ \\
\hline
\end{tabular}

Table 3.3 Properties of link beam steel 


\section{Chapter 4 \\ Experimental Procedure}

\subsection{Toat Sotup}

The overall teat set-up is shown in Floure 4.1. The loads and resctions were applied to the walls whth two loading beams an the baes of each well. The longliudind reinforcing bars of both walls were wlded to the loading beams. The weat losding boam wes post-tensloned to the reaction floor of the laboratory with threaded rods. The reculing force clemping the weat wall to the floor was $800 \mathrm{kN}$ (670 $\mathrm{kN}$ on the east and $130 \mathrm{kN}$ on the weat rods), or about twice the expected ultimate epplied load. During reating the wedt wall is expected to remain fixed to the reaction roor.

Figure 4.2 illustrates the manner in which the teat set-up simulates the relative displacement, $\delta$, between the two walls which remain eacentially parallel

The east wall is loaded vertically such that 1 remains parallel to the wost wall. The reversed cyclic loading applied to the ease well simulstes the ewocts of sciamic loading. Loads are applied to the losding beam of ths east wall by two losding syatems, one pessing through the midspan of the link beam and the other at the east end of the well. During teeting these loads are applied such that the east losding beem remains horkontal. In order to produce revereed cyclic losding, two separate jecking sysems were providsd. For upwerds loading, a single $120 \mathrm{kip}$ $(530 \mathrm{kN}$ ) hydraulic ram reacted againat the bottom of the east losding baem directly under the midspan of the link beam. For downwerds loading, two 60 kip (267 kN) hydraulic rems under the reaction floor produced tension in the thresdad rods stieched to the beeding beem. To maintain the loading boam in a hericontel poetlion, 60 kip (207 kN) hydralle rems, bested at the exet end of the loading bean provided the requined loveling forces.

Both walls were reatreined from ous-d-plene or keceral movement. The top of the weat wall was breced with hoay atcel angles to a still fram. Tho Eact wall wes restrained egainst leterd movement with heavy duty roliers fixed to sili braces. 


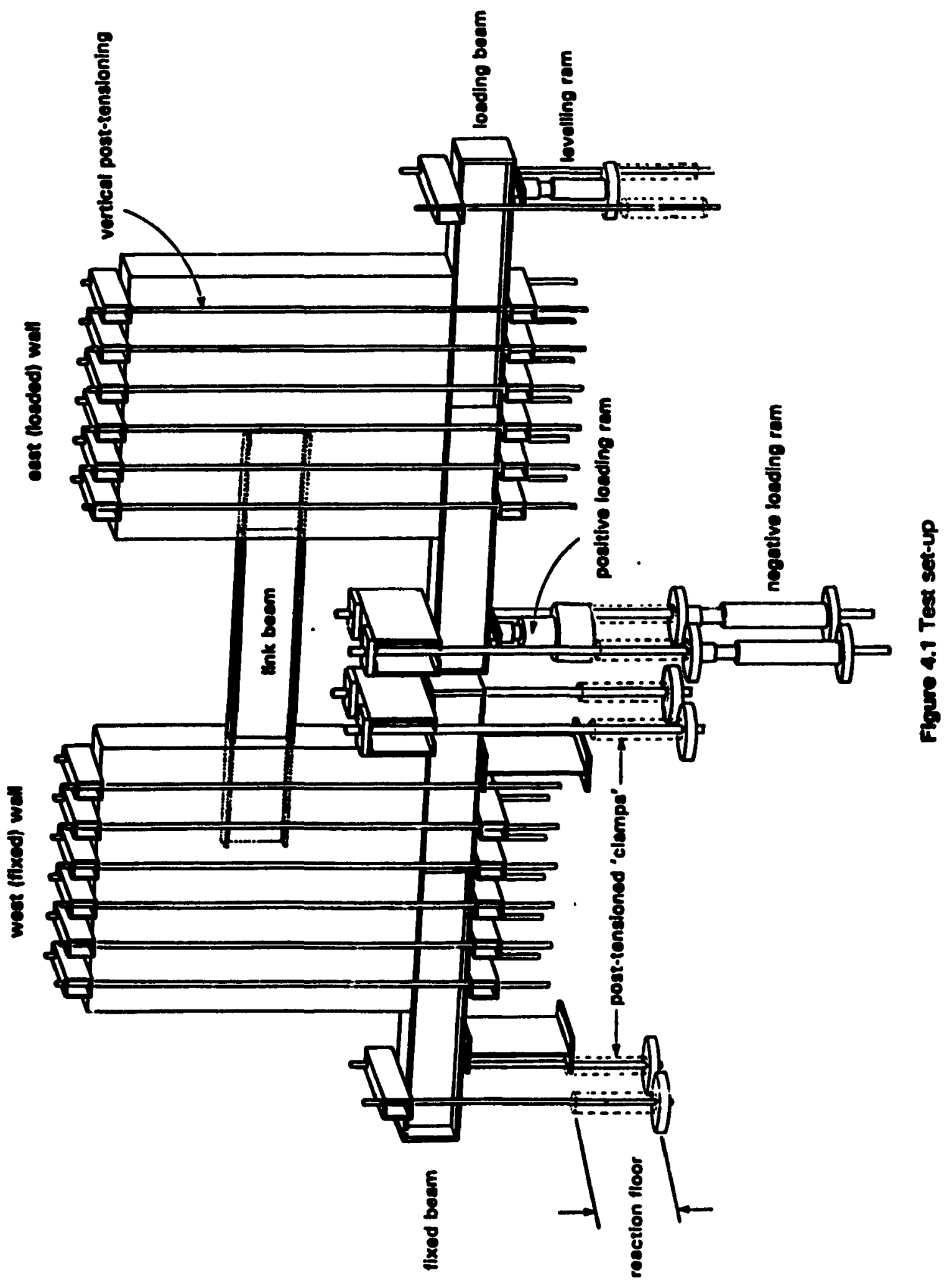



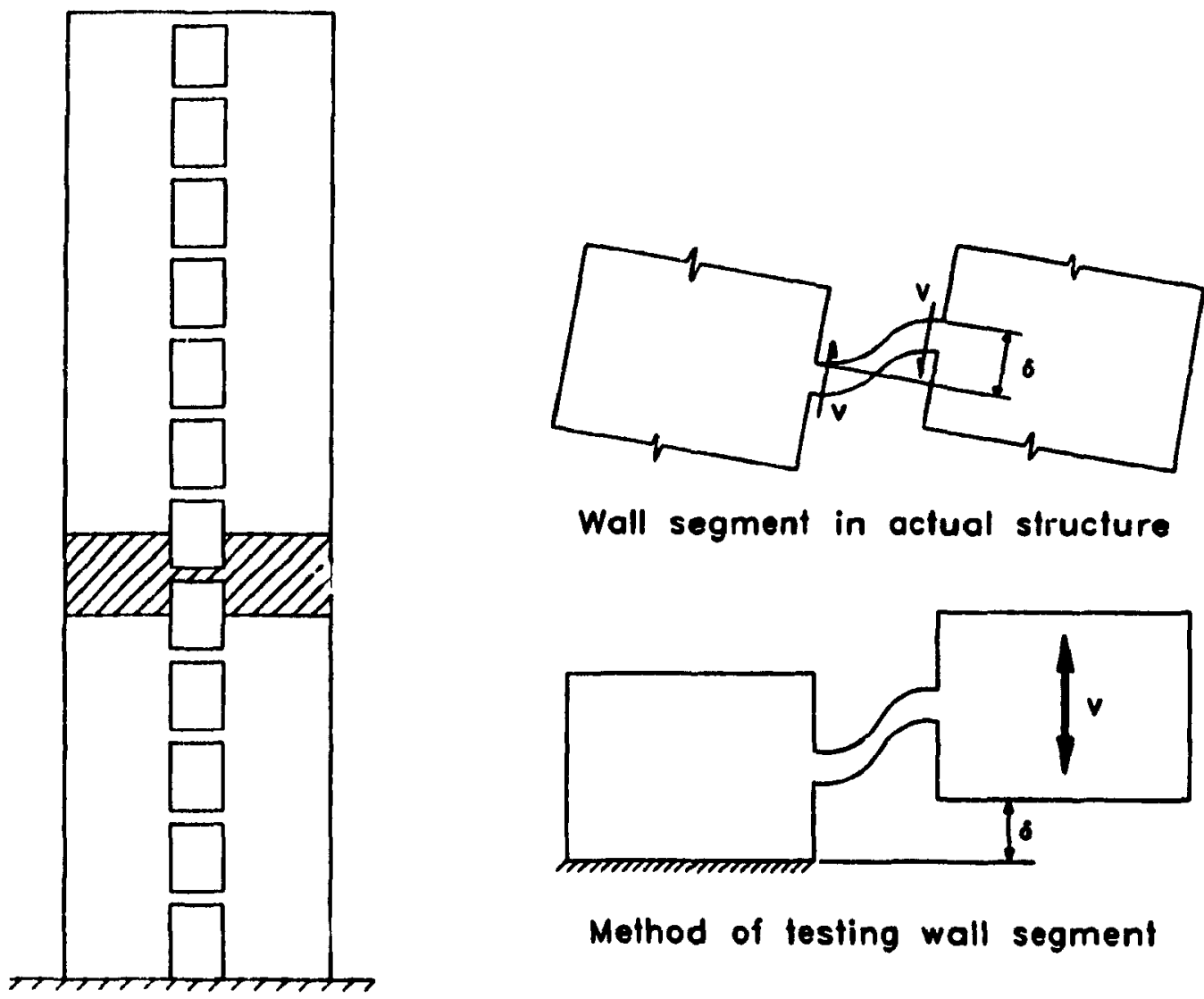

Wall segment in actual structure

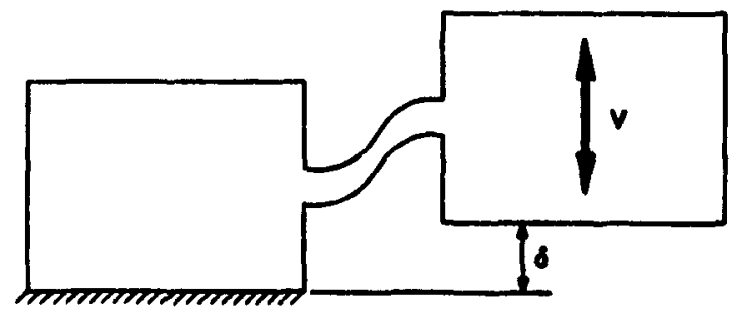

Method of testing wall segment

Coupled Woll System

Figure 4.2 Method of simulating actual coupled wall response

In order to simulate the compreasive streseces in the weils dus to crevily loods, potttensioned vertical rods were atrapped to the exterior of each well ses shown in Fig. 4.1. Four by six inch (101.6 $\times 152.4 \mathrm{~mm}$ ) hollow sections were clamped around the top of the well and the bottom of the loading beam with one inch $(25.4 \mathrm{~mm}$ ) high strength threaded rods. Each rod was post-tensioned with 25 kips (111 kN). The rods were speced at 9 inch (228.6 mm) centres resulting in a uniform applied pressure of 480 pal $(62 \mathrm{kPa})$ on each wail. 


\subsection{Inotrumentation}

Figure 4.3 shows the instrumentetion used for both specimens. An array of linear voltage differential transformers (LVDTs) measured the vertical displacements of both the concrete wells and the loading beams. This instrumerketion allowed the differential movement and the rotations of each wall to be determined. The LVDTs were set up so that they could measure retative displacemente of $\pm 150 \mathrm{~mm}$. The predicted unimate displacement wes epproximetely $\pm 125 \mathrm{~mm}$. Diel gauges attached to the bading beams permitted visual control during bading (see Fig. 4.3(a)).

Ten electrical reabtence atrain gauges were ghed to the reinforcing bers in each well, six measuring the streins in the main ventical reinforcement at the lovel of the link bean flanges and four on the horizontal ties loceled above and below the link beam thanges (see Fig. 4.3(a)).

Five strain gauges were glued to the top and bottom thanges of the link bean to determine the flexural strains in the flanges. In addition. strains were obteined from mechanical strain targets having a gauge length of $200 \mathrm{~mm}$. These targets were punched directly into the surface of the steel. Addhiond electrical reaiatence strein gauges were boceted at the ends of each fiange near the flange tips. Strein veriction either acroes the fianges or through the flange width would indicate loced fiange instabiny. Three atrain gauga rosettes were located along the exposed web of the link beam (on the side withouk the stifieners) in order to record the shear strains in the web. Additional strein measurements were taken between mechenical strein targets, punched into the steel a $100 \mathrm{~mm}$ gauge lengths. For Specimen 2, two additlonal strain gauge rosettes were located on the embedded portion of the link beam web, $300 \mathrm{~mm}$ into the concrete wall. These strain measurements enabled the determination of shear streins in the embedded link beam web.

For Specimen 2, a total of 12 strain gauges were located on the front feces of the walls, three above and three below the link beam on each well. These gauges measured the atrain distribution across the faces of the walls reacuing from the bearing of the link beam flanges.

LVDTs and diel gauges were used to record the differential horizontal displacements of the walls.

As shown in Fig. 4.3(b), Specimen 1 is inserumented whin mechanical strain targets over a gauge length of $200 \mathrm{~mm}$ in order to determine the ventical concrete surface atrains over the embedment region at the fece of the wall. Due to in-plene spliting, the cover concrete separeted from the embedded regions and hence the streins measured at the concrete surfece were not representative of the strains near the embodded region. Therefore these strain tangets were not 


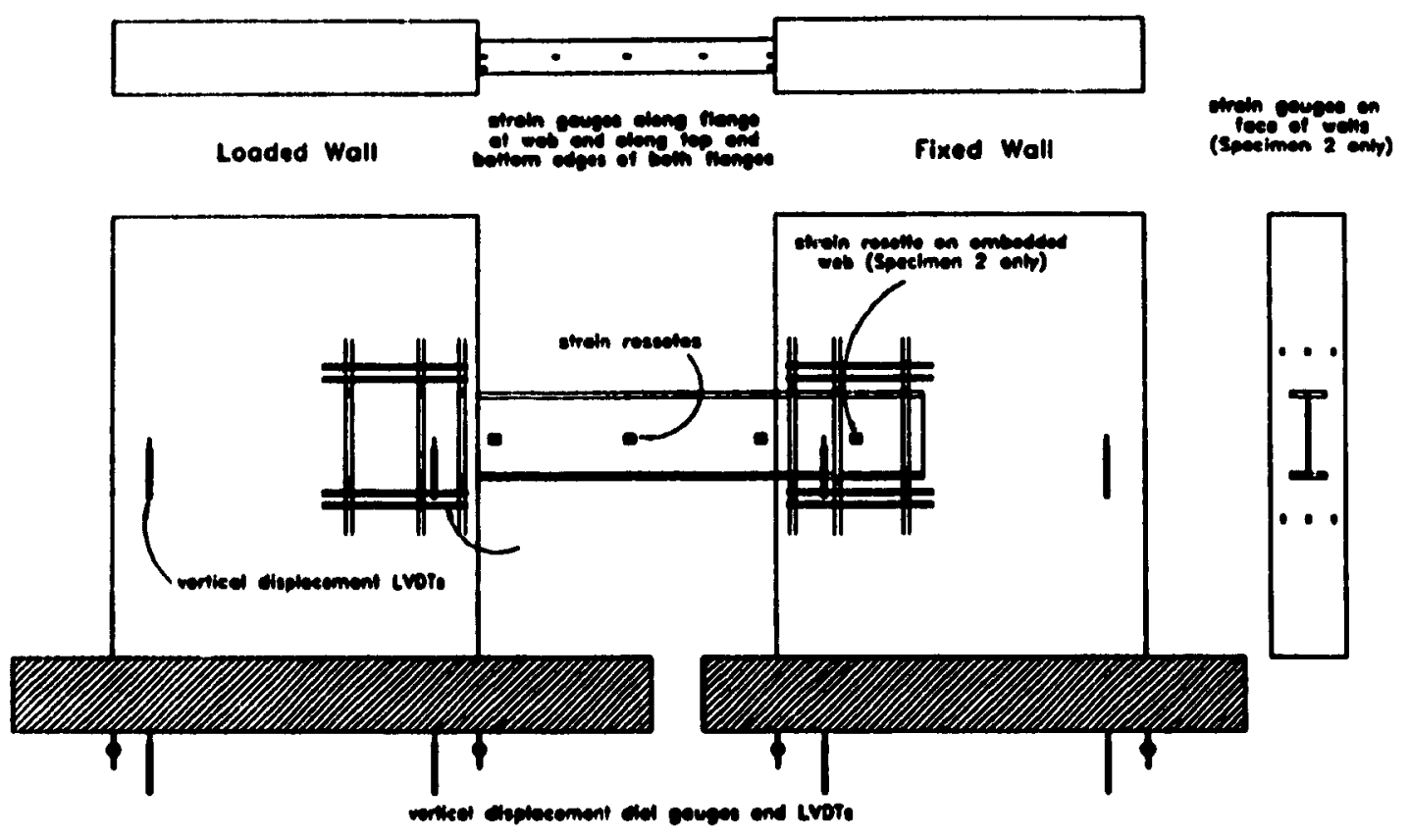

(a) electrical resistance strain gauges ond LVDT's

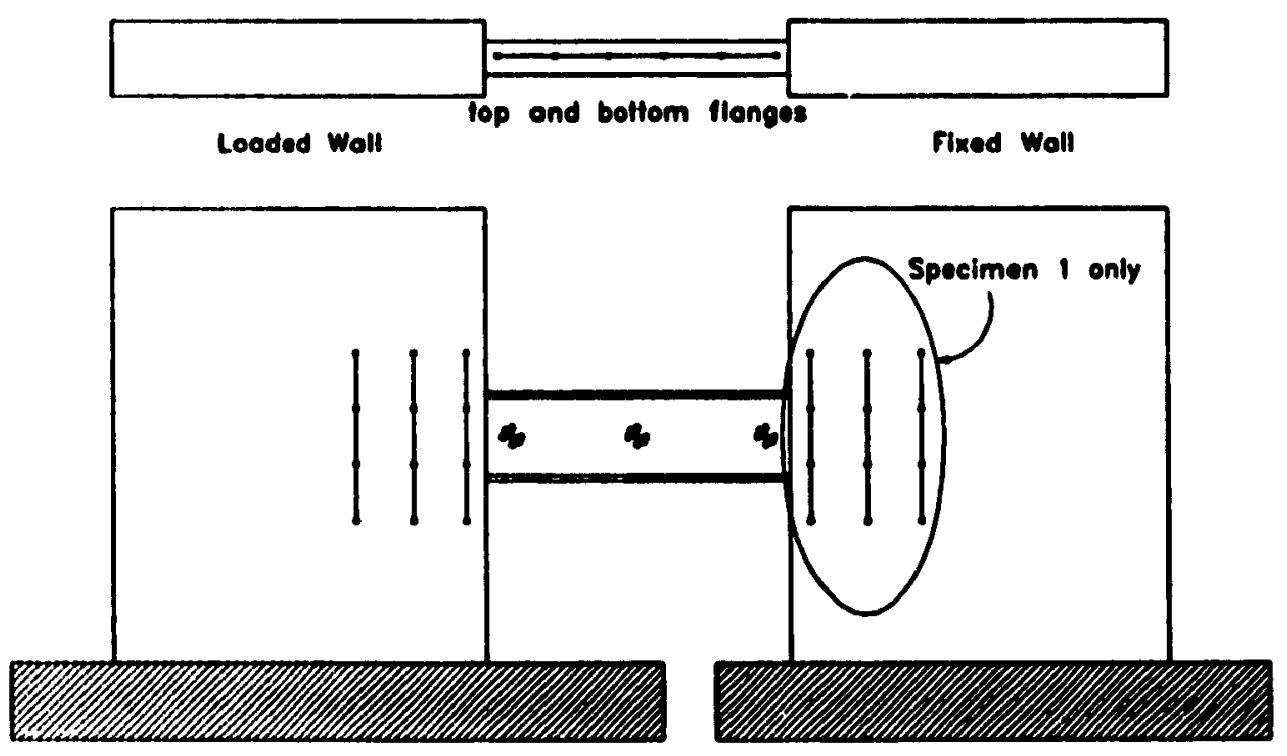

(b) mechonical strain largets

Figure 4.3 Spectmen inatrumentation 


\subsection{Loading Hiatory}

The loading history for each specimen is shown in Fig. 4.4. In order to control the teating. loed versus deflection responsus for the east wall were plotted as the teeting progressed. Upwerds loading and deflections were considered to be positive. In the first cycle, loading was applied to a predetermined peak load followed by three reversed cycles at this load lovel. This loeding control was used unil general yielding was obsenved in the link baem. Cenerd yilking was determined when a stonificent chenge in the losd destection response was observed, correaponding to observed Making' of the whinewesh on the link beem wob. Aler generdl yiliding

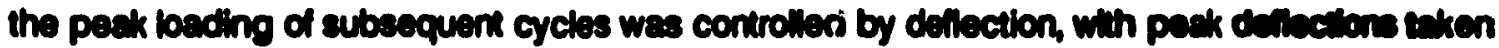
as muliples of the deflection at general yielding, $\delta_{\mathbf{r}}$.

\subsubsection{Load Hitsiony of Spectmen 1}

The first two peak loeds $( \pm 100$ and $\pm 200 \mathrm{kN}$ ) represented one third and two thinds of the predicted yield strength, respectively. The third peak load ( $\pm 250 \mathrm{kN}$ ) corresponded to the first sign of yiekling elong the centretine of the link beem web. The firte three peek loeds exh"bined fun elastic beheviour. The fourth peak load ( $\pm 300 \mathrm{kN}$ ) corresponded to general yielding of the link beam web at a deflection of $\delta_{y}= \pm 12 \mathrm{~mm}$. Subsequent peak dellections corresponded to $\pm 2 \delta_{y}$, $\pm 4 \delta_{y} \pm 6 \delta_{y}$ end $\pm 8 \delta_{y}$. Ater the specimen had been cycled three times at a dieplacement of $\pm 8 \delta_{y}$ it was loaded, monotonically to a displacement equivelent to $+\mathbf{1 0 . 5 6}$.

\subsubsection{Load Hibtory of Specimen 2}

The firs two peak loads $( \pm 100$ and $\pm 200 \mathrm{kN})$ represented approximately one and two thirds of the predicted yield strengith, respectively. The third load atege $( \pm 275 \mathrm{kN})$ corresponded to generd yiblding of the link beam wob at a deflection of $\delta_{y}= \pm 11 \mathrm{~mm}$. Subsequent peak 

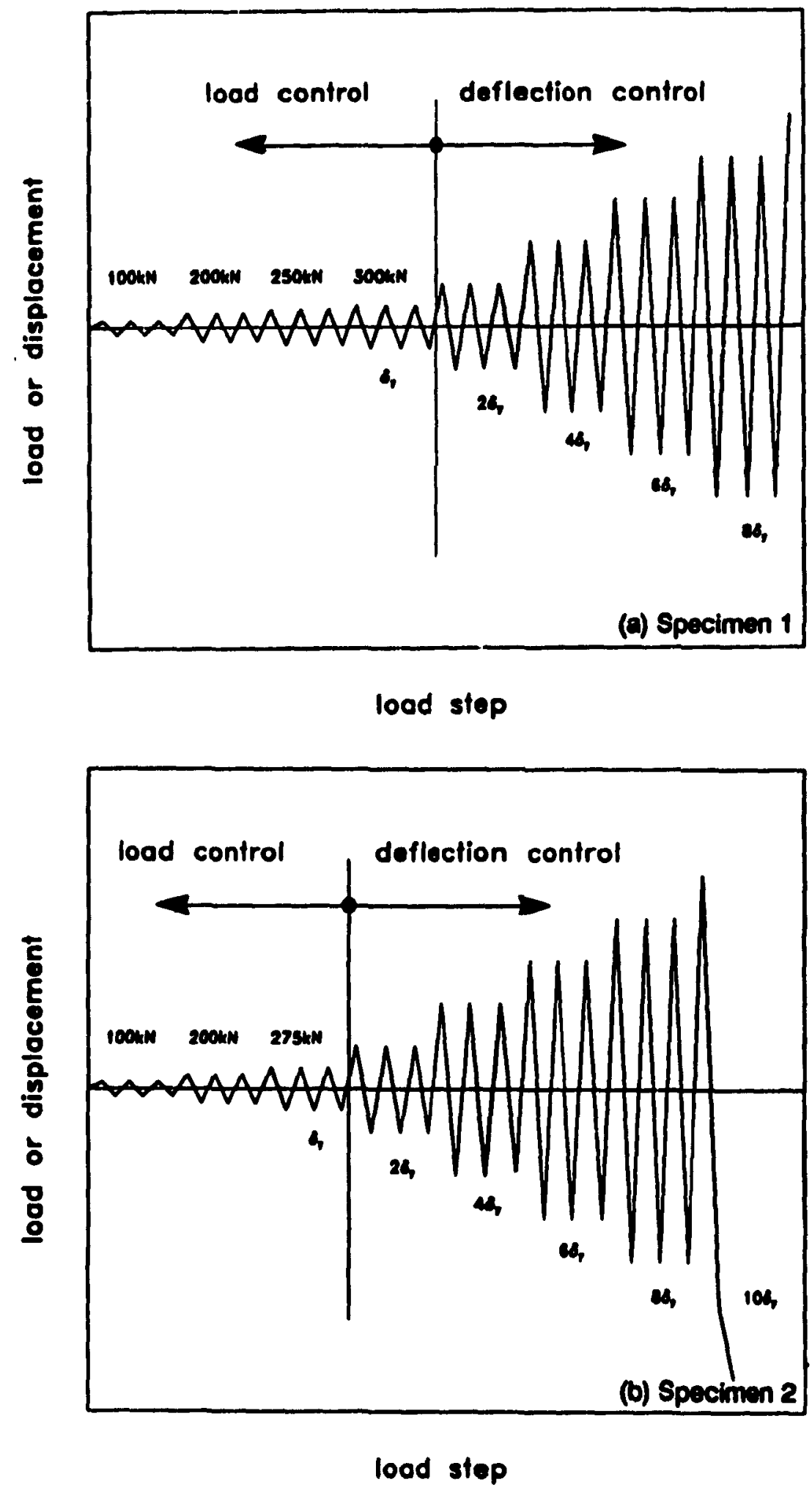

Figure 4.4 Loed hibtorles of Specimens 1 and 2 
deflections corresponded to $\pm 2 \delta_{y} \pm 4 \delta_{y,} \pm 6 \delta_{y} \pm 8 \delta_{\text {, }}$ and $\pm 10 \delta_{y}$. Ater the specimen had been cycled once at a displacement of $\pm 10 \delta_{p}$, it was loaded monotonically to a displacement equivalent $10-13.6 \delta_{p}$. 


\section{Chapter 5 \\ Experimental Results}

This chapter presents a detalled description of the observed experimental behaviour of Specimens 1 and 2. The letrers A and B represent positive (upwards loads and denections) and negative (downwards loads and deflections) cycles, respectively.

For the losd-deflection responses, the losd corresponds to the shear transmitted through the link bean and the dellection represents the vertical displacernent of the east wall reletive to the west wall. The displacements have been corrected to account for measured, cilferential rotations of the walls. It should be noted that these differential rotetions were very small throughout the testing of both specimens and resulted in only minor corrections to the deflections. The key stages in the responses of both specimens are presented in Table 5.1. Detalled observations of each peak load for both specimens are given in Appendlx $\mathbf{B}$.

\begin{tabular}{|c|c|c|c|c|c|c|}
\hline & \multicolumn{3}{|c|}{ Specimen 1} & \multicolumn{3}{|c|}{ Specimen 2} \\
\hline & Step & $\begin{array}{l}\text { Shoer } \\
\text { (KN) }\end{array}$ & $\begin{array}{l}\text { Derin' } \\
(\mathrm{mm})\end{array}$ & Step & $\begin{array}{l}\text { Shoer } \\
\text { (KN) }\end{array}$ & $\begin{array}{l}\text { Defin } \\
\text { (mm) }\end{array}$ \\
\hline first cracking of joint region & 4 & \pm 200 & \pm 4.6 & 4 & \pm 200 & \pm 4.9 \\
\hline first local yiolding of link beam & 7 & \pm 250 & \pm 8.3 & \multicolumn{3}{|c|}{ not claanty defined } \\
\hline general yielding of link beam & $\begin{array}{l}10 A \\
103\end{array}$ & $\begin{array}{l}300 \\
300\end{array}$ & $\begin{array}{r}12.0 \\
-11.1 \\
\end{array}$ & $7 A$ & $\begin{array}{l}274 \\
-274\end{array}$ & $\begin{array}{l}11.2 \\
-9.8\end{array}$ \\
\hline $\begin{array}{l}\text { tensile cracking along compressive } \\
\text { strut }\end{array}$ & $\begin{array}{l}168 \\
17 A\end{array}$ & $\begin{array}{l}385 \\
374\end{array}$ & $\begin{array}{r}.50 .1 \\
80.1\end{array}$ & $\begin{array}{l}13 A \\
138\end{array}$ & $\begin{array}{l}358 \\
386\end{array}$ & $\begin{array}{r}44.2 \\
-44.5\end{array}$ \\
\hline ultimate capacity of link beam & $\begin{array}{l}19 A \\
188\end{array}$ & $\begin{array}{l}388 \\
409\end{array}$ & $\begin{array}{r}70.3 \\
-75.5\end{array}$ & $\begin{array}{l}188 \\
21 A\end{array}$ & $\begin{array}{l}466 \\
486\end{array}$ & $\begin{array}{r}-90.3 \\
88.2\end{array}$ \\
\hline maximum obsenved deflection & END & 34 & 122.8 & END & 381 & -150.3 \\
\hline
\end{tabular}

Table 8.1 Summary of critical load stages 
Figure 5.1 shows the load-deflection response for specimen 1. The first horizontal cracking in the wall, at the lovel of the link bean flanges occurred at peak loads $4 A$ and $4 B$ corresponding to shears of $\pm 200 \mathrm{kN}$. From the strain rosette readings, local shear yielding first occurred at the micheight of the llnk beam web at a shear of $\pm 250 \mathrm{kN}$, at peaks $7 \mathrm{~A}$ and 78 . From elastic analysk, besed on the measured yield atreas of $320 \mathrm{MPa}$ in the wob material, the predicted yield shoar is $292 \mathrm{kN}$.

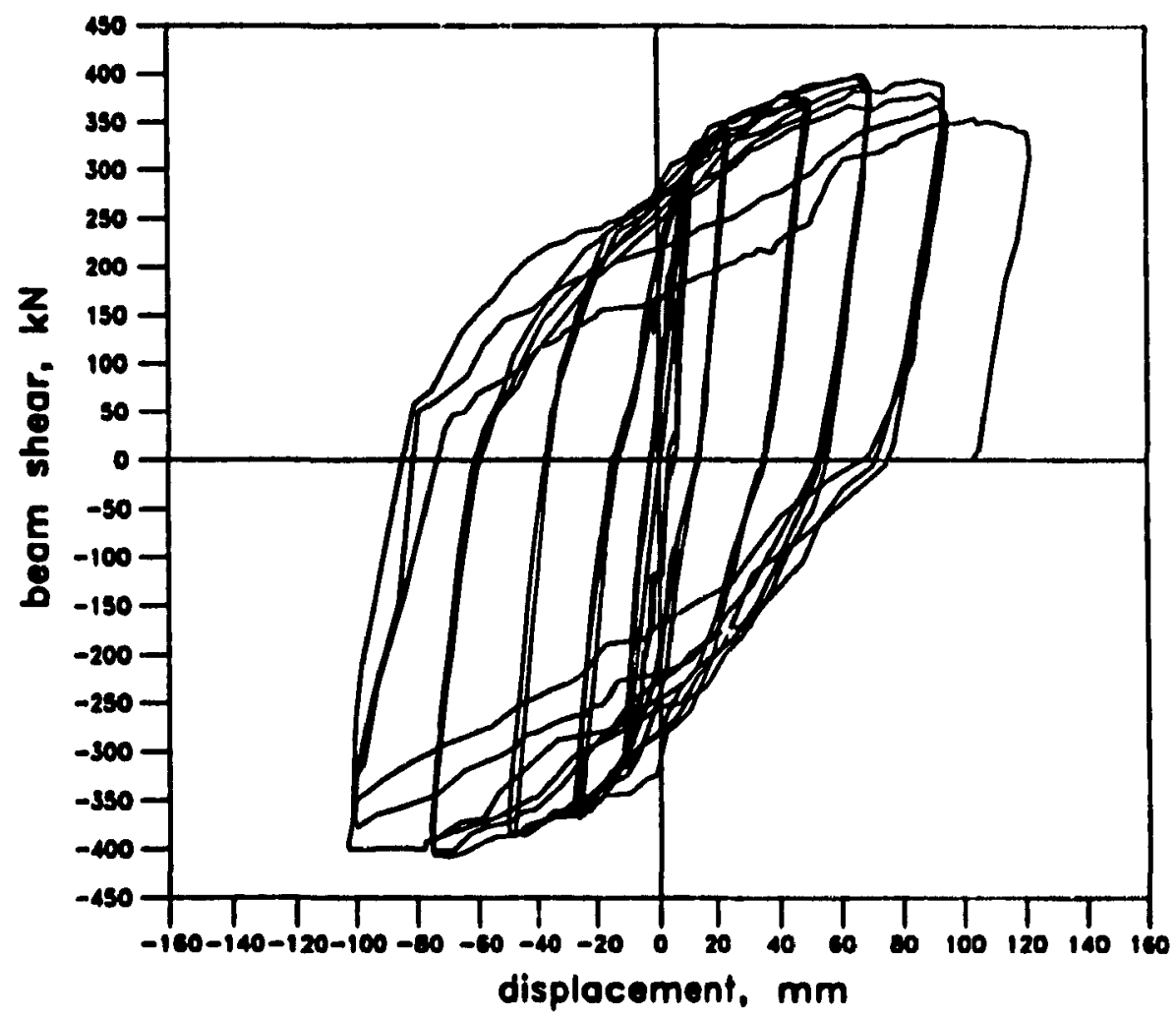

Floure 8.1 Link beam shear versus relative vertical displacement of Specimen 1

Ceneral ylelding of the link beam web, occurred at peak load 10A, at a load of 3,03 kN and a vertical displacement of $12.0 \mathrm{~mm}$. At this stage, thaking of the whitewash on the link beam web occurred and there was a noticeable change in the load-deflection response. Cenerel yielding in the negative direction occurred af peak load 108, at a load of $300 \mathrm{kN}$ and a displacememt of $-11.6 \mathrm{~mm}$. The predicted yielding shear is $\pm 308 \mathrm{kN}$. The peak diaplecement, $\delta_{p}$ at general yiolding, was taken as $\pm 12 \mathrm{~mm}$. 


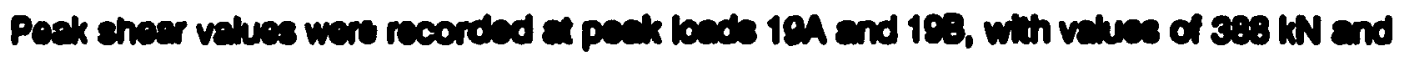

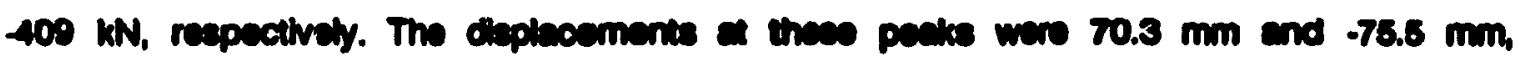

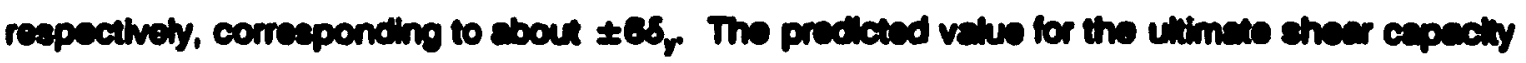

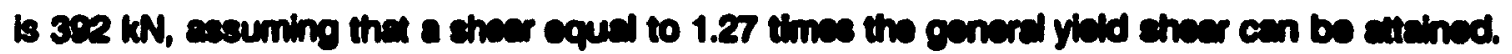

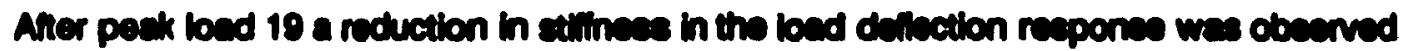
whin cycling and the paek loed velues begen to dxcins. By the end of pack loads 241 and 248 ,

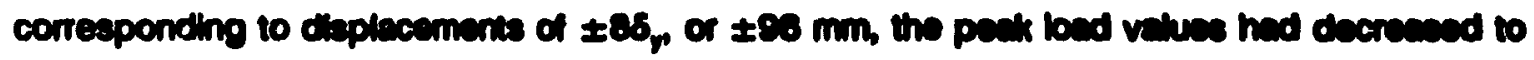

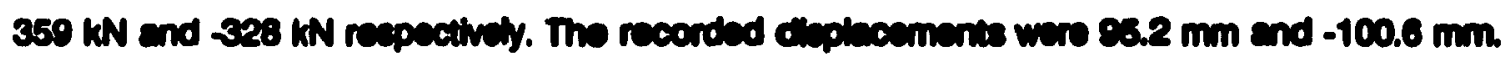

The specinen was fincly losded monotoriacly in the pocitive direction to a peak lond of

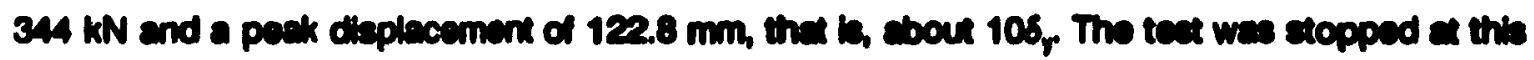

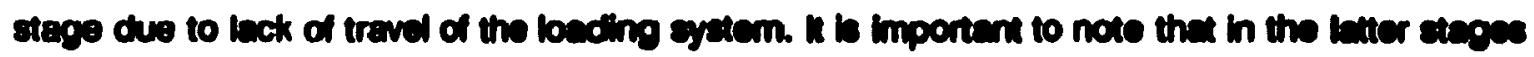

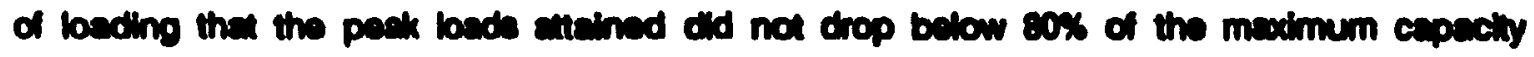
obtained. A photogreph of Epecimen 1 elier tecting is shown in Fioure 8.2.

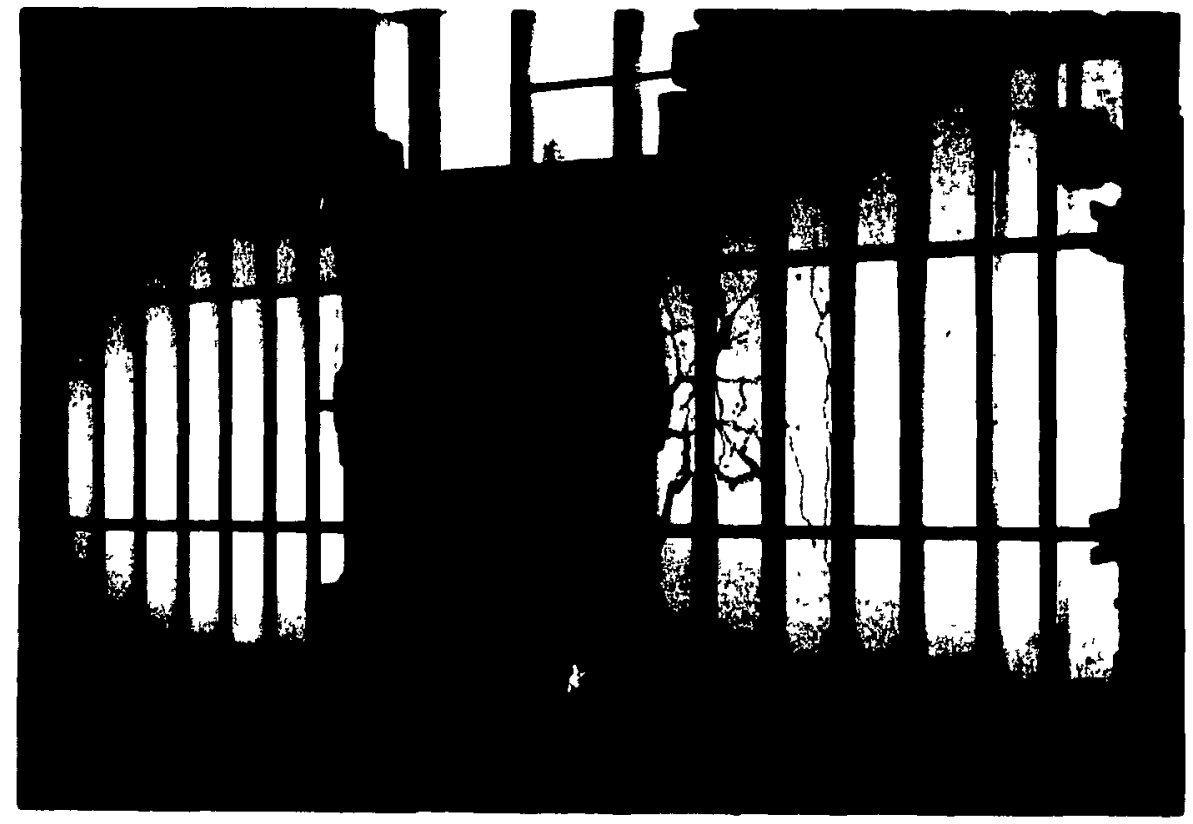

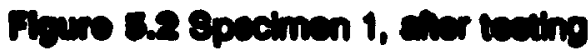

\section{B.1.1 Unik Desm Recponse}

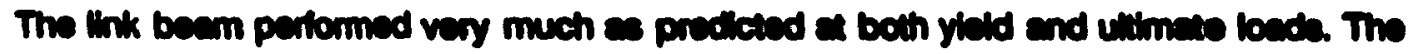

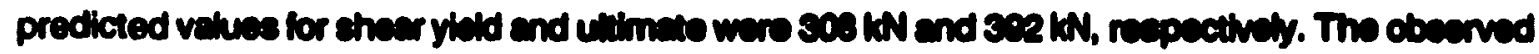

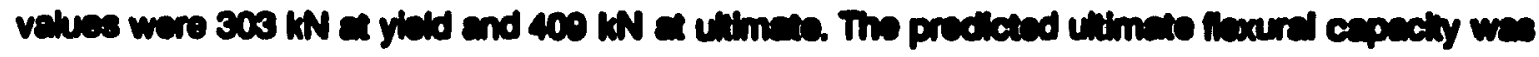
compured to be $203 \mathrm{kN} \cdot \mathrm{m}$, comeeponding to en eppind shem fores over $483 \mathrm{kN}$ over the

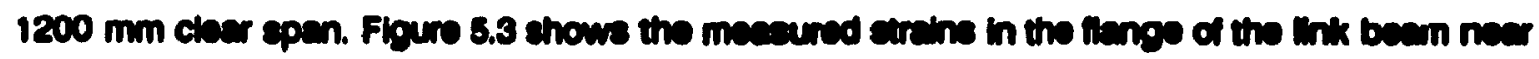


the end of the clear spen. As can be seen, firet yielding was meacured in the flange of the ink beam at about 4S. Two factore contributing to the premature locel yielding of the flange where the increase in clear span due to both spaling and outwerd retchoting of the link beam, and the distreses ceused by crippling of both the web and finges in the cmbedinent. Apent from the bocalisod yisteling of the fienge, very litile fiexurd deformation of the link beam was observed

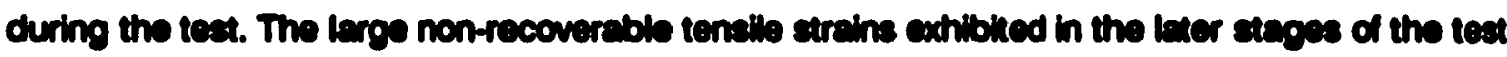
(see Fig. 5.3) are a reauk of the locel nange buckling, in the vicinity of the strain gauges, brought about by crippling of the wob at the spalled face of the wall. Cripping of the wob in the embedmont was eatimated to have occurred at peak load $17 \mathrm{~A}$ with noticeable flexural yialding of the last set of aliteners at the end of the clear span.

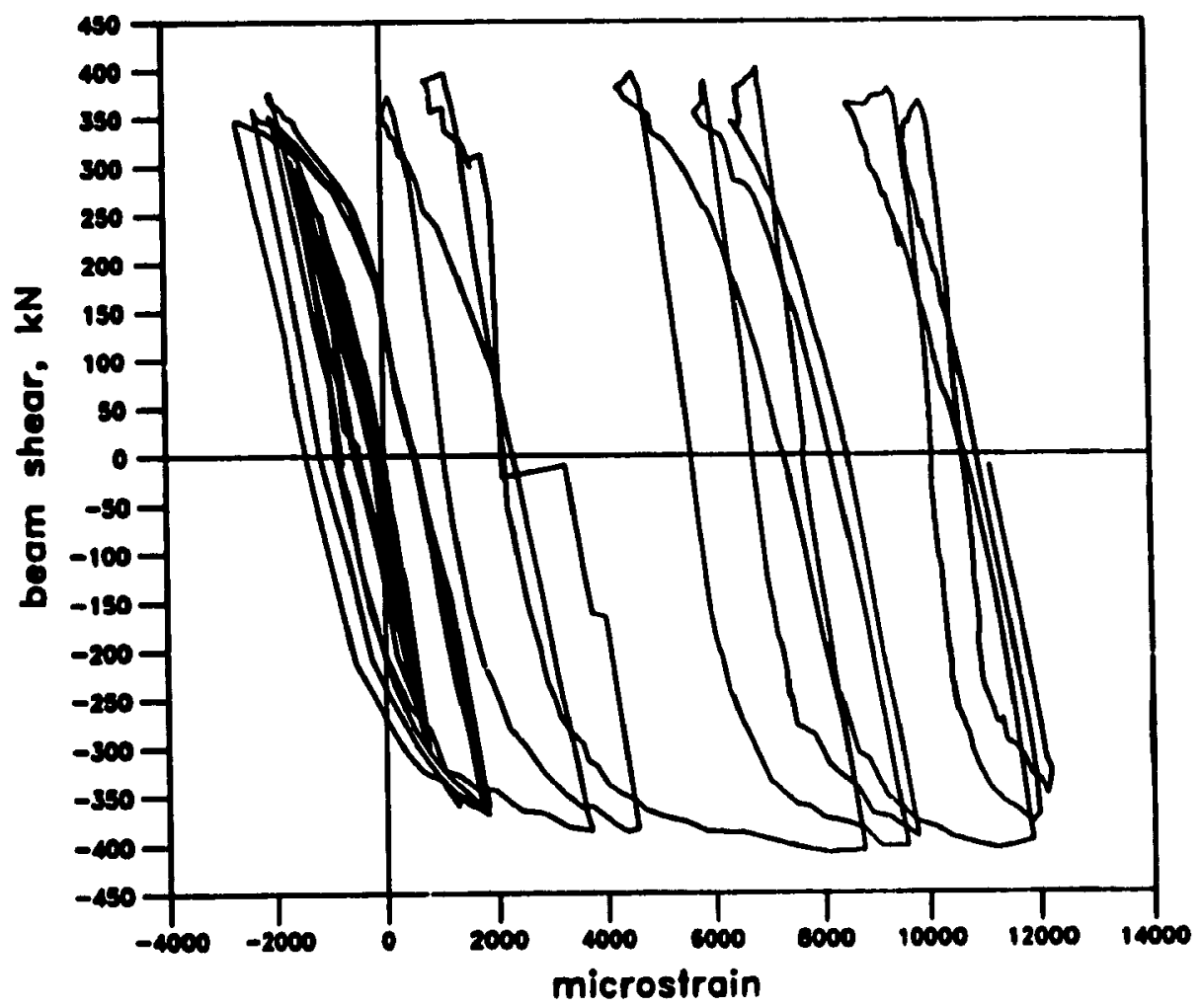

Floure 8.3 Mescured streins in the link baem fienge of Specimen 1

Figures 5.4 and 5.5 show the link beam ambedmem just before and efter removal from the concrete. The crippling of the wob and fienge, put inside the embedment, ks clearly evident. Tearing of the link boem web cocurred at the beck of the embedment, in the heex efiected zone 


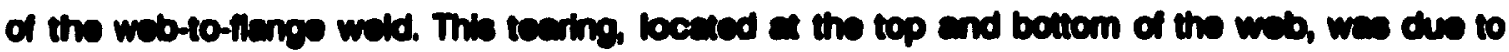
shaer yialding of the cmbedded web.

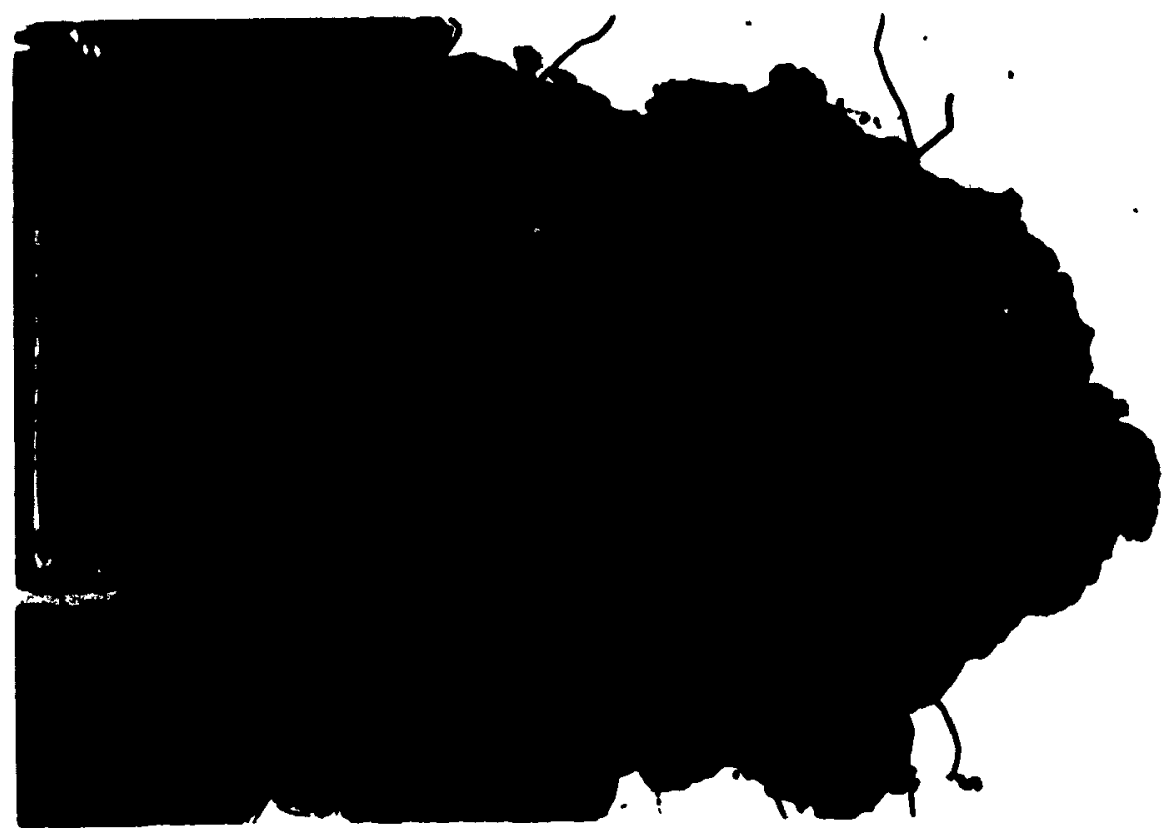

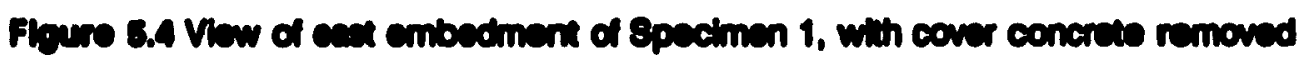

Figure 5.4, shows the large oup ex the end of the embedinent dus to the movement of the link baan out of the conorete and the pronounced chear deformation vibible at the end of the

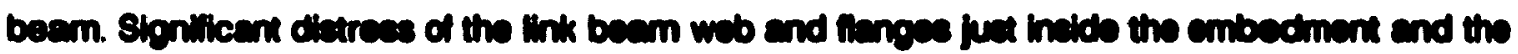
lerge gep between the link bean fiange and the concrete at the top of the link beam new the front lece ere abo evident. The permenemt sheer deformetion reached in a reletwe horteonid movement of $13.2 \mathrm{~mm}$ between the top and botion fingese. The overell hight of the cection decresaed $19.8 \mathrm{~mm} 10350.2 \mathrm{~mm}$ a a bostion cbout $76 \mathrm{~mm}$ ino ths embedinent. Figure 8.8 shows en overell viow of the link beem eter removel from the wein.

\subsubsection{Reinforead Conervie Recpenso}

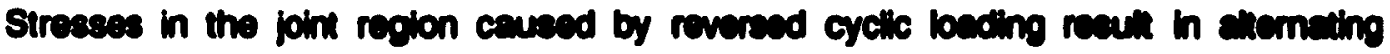
comprescion zones in the concrite, firt at the top and then at the bottom finnese of the link

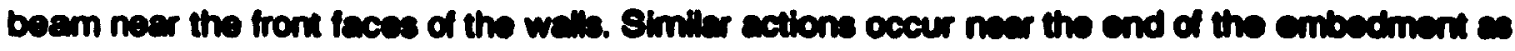

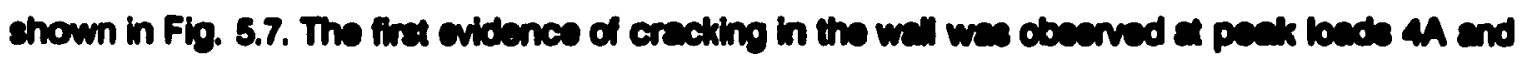

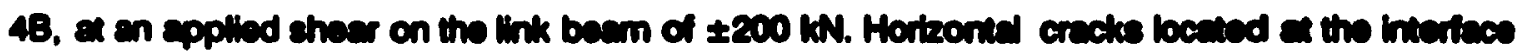

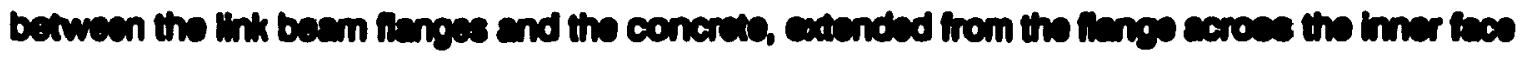




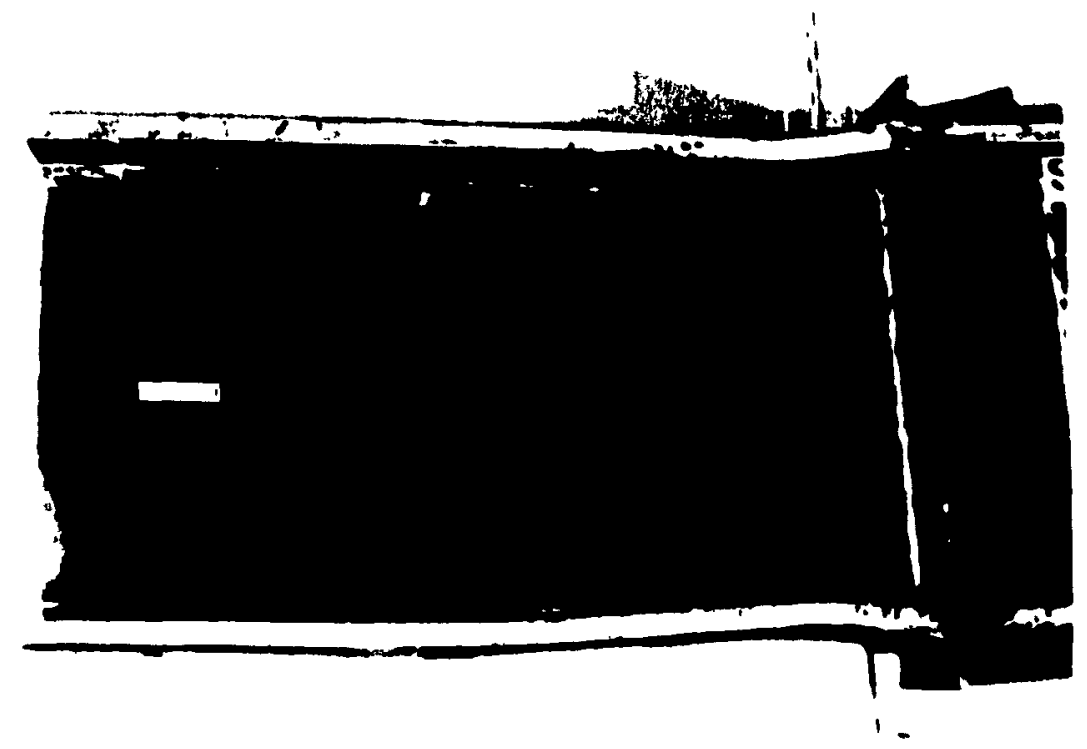

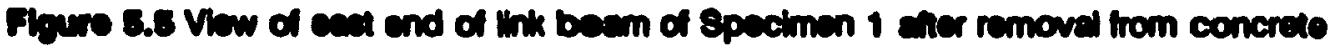

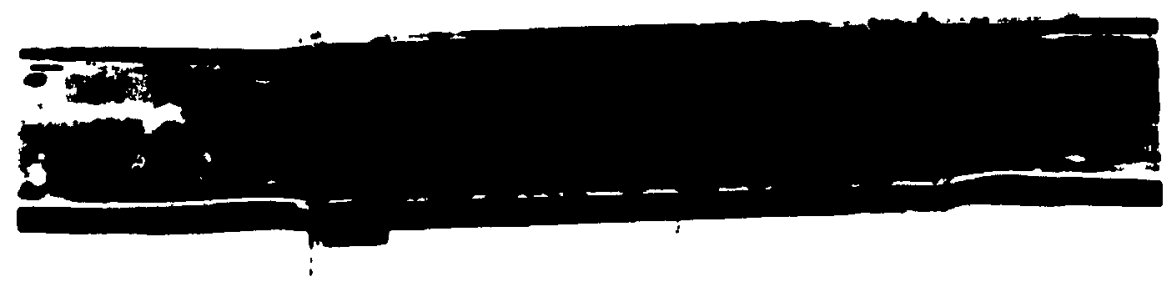

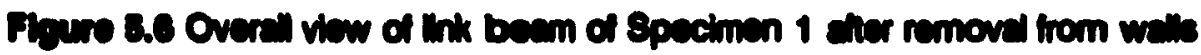

Of the well to the side faces of the will (cos Fig. 8.8).

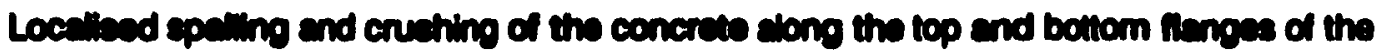

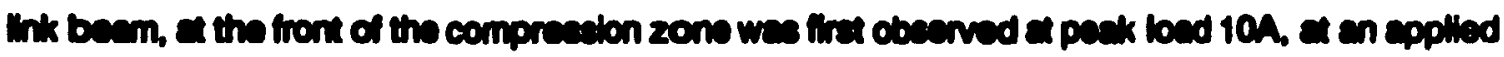
chear on the link baem of $303 \mathrm{kN}$. By peck load 13, this ditheas was ovident en ell four fiengo-

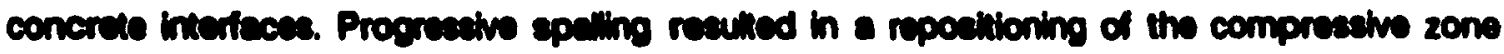

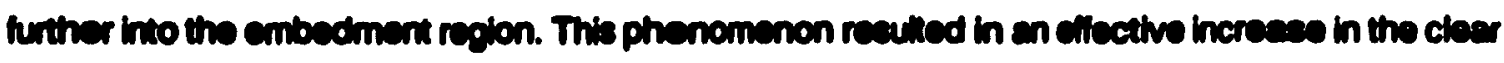
span of tho link bean (ces Fig 5.70). 


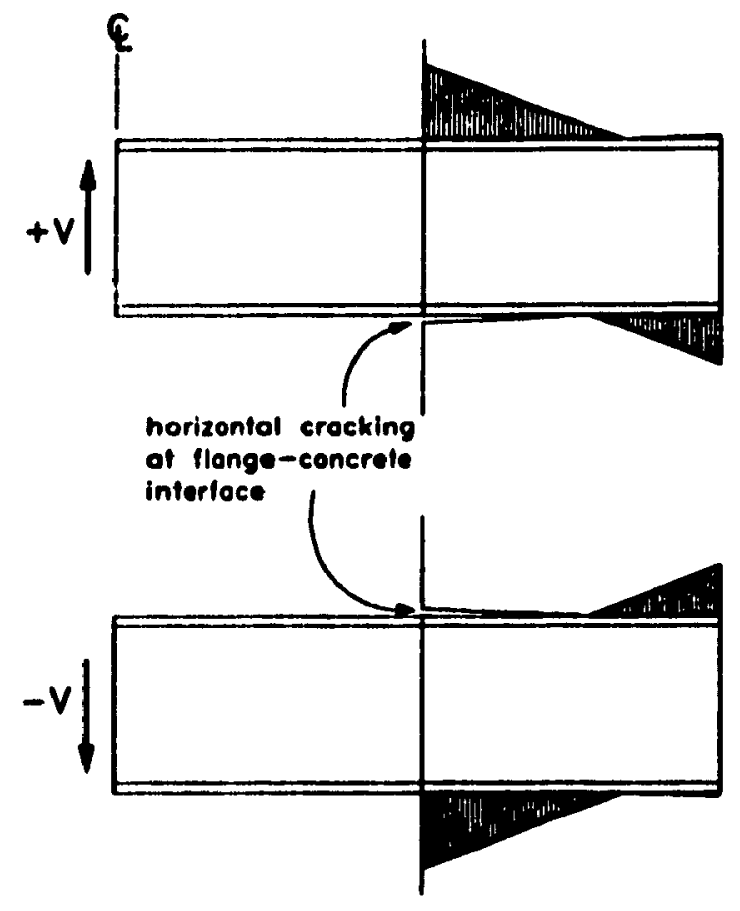

(a) before spalling
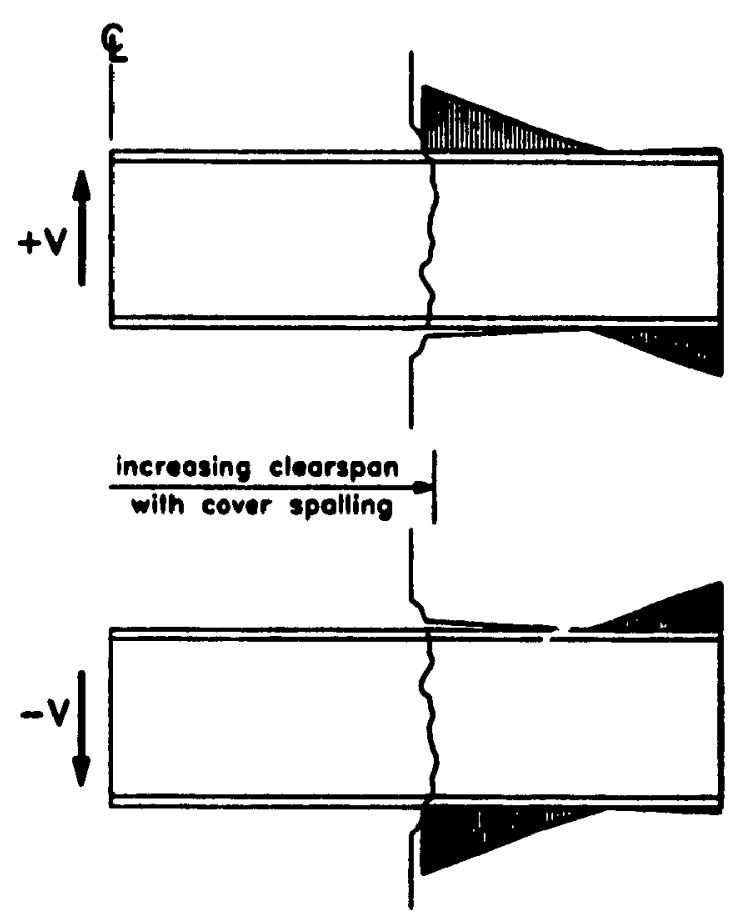

(b) ofter spalling

Figure 8.7 Akerneting comprescion zones dus to revereed cyclic loading

Funther cracking reacked in the spaling of a somi-circuler block of cover concrete at the inner face of each wall as shown in Fig. 5.9. Al peak load 21A, the outer portions of this dectached block of concrete fell off, beving sound concrete contined between the link beam fienges, which served to stitien the wab in this region. Dus to the relative movement between the link beam and the concrete, delamination st the concrete occurred along a vertical plane dellineated by the trange tips. Although doleminer ion occurred, the outer concrete is reinforced with the vertical and horizontal reinloreing bars and the concrecte between the thanges b confined by the flangese and serves to siliten the wob. The plane of deleminetion in the ease wall at peak loed $21 \mathrm{~A}$ is shown in Figure 5.10.

The first vertical crack appeared in the oaet wall at peak load 168, it an eppliod shear in the link beam of $380 \mathrm{kN}$. This crack wes located $600 \mathrm{~mm}$ from the inner face of the wall, the location of the end of the link beam embedment. A similur creck sppeared in the weat wall, 


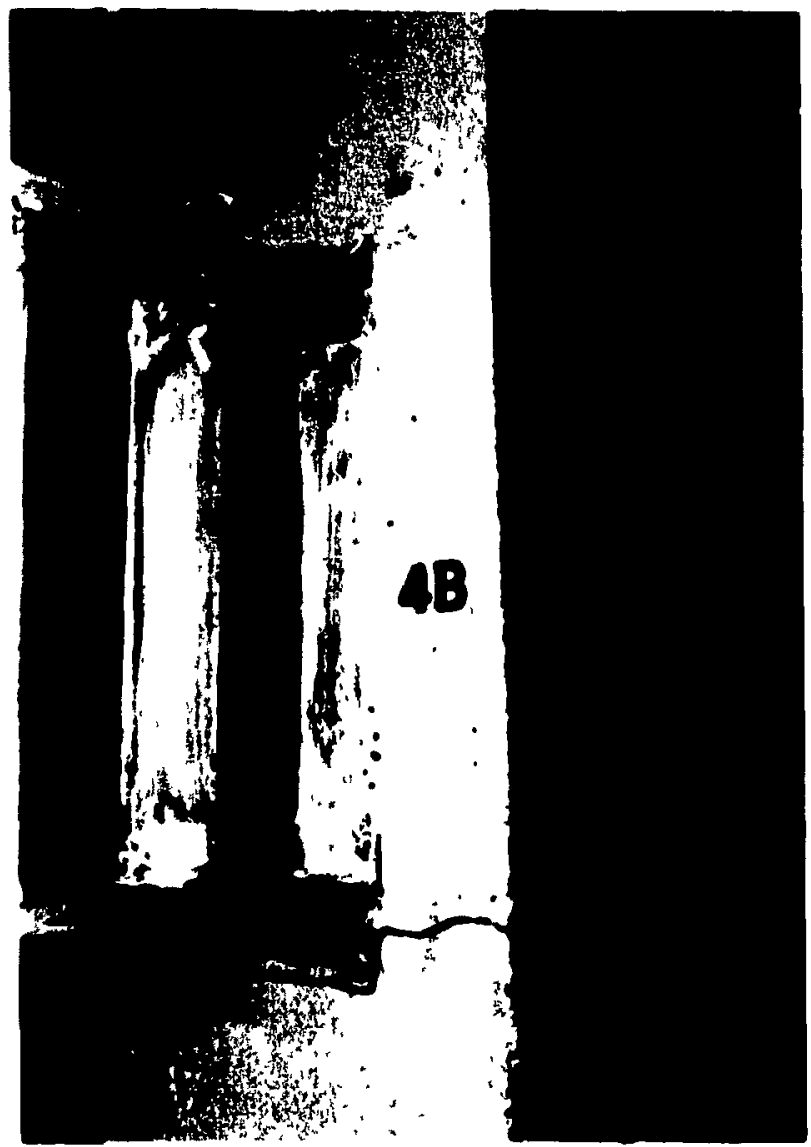

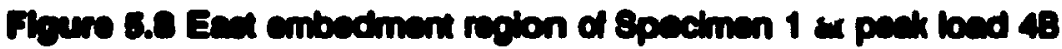

$850 \mathrm{~mm}$ from the inner feces of ths well at peak load $17 \mathrm{~A}$

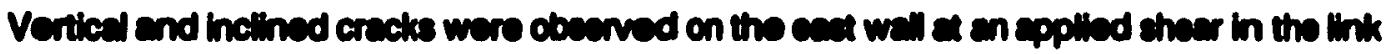

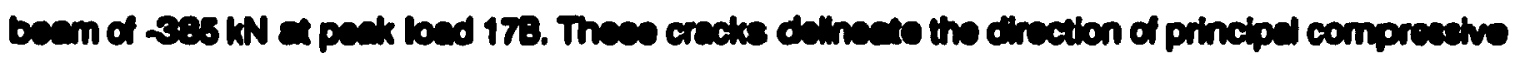

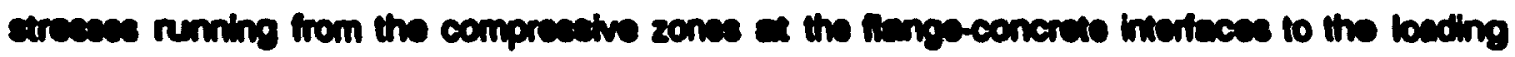

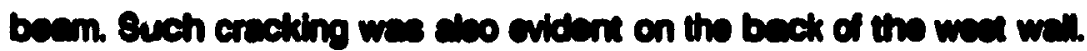

A bage region of deteminemed conorete, deswinined by a holvow sound when tepped.

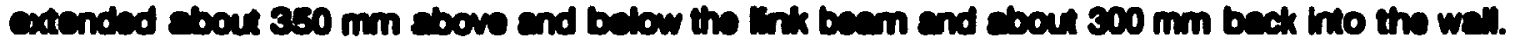

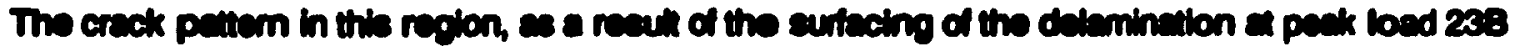

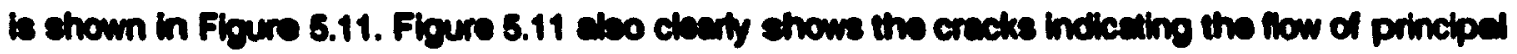
compreasive streases.

The servere dietrese of the cmbodinent region new the inner face of the wall extendod cbout $100 \mathrm{~mm}$ into the wall by the find steges of the text, nevining in cxposure of the firet ect of 


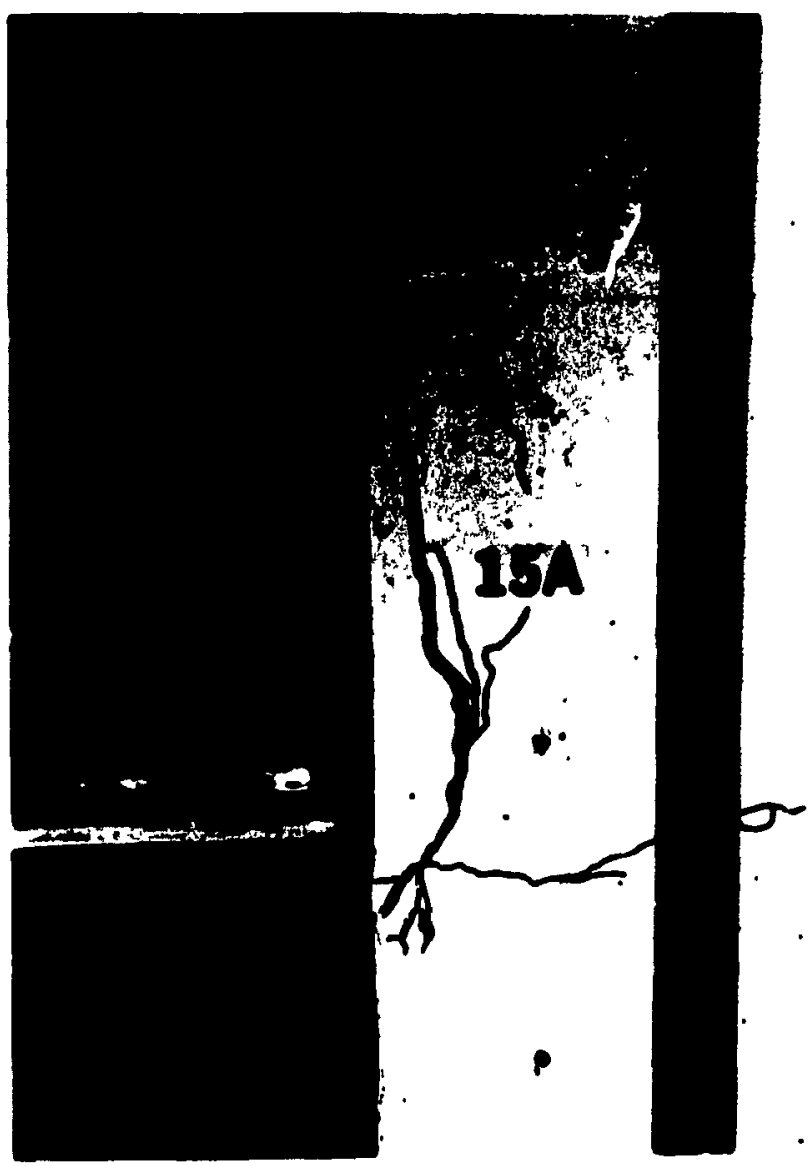

Floure 8.0 Eat combodment region of Epacimen 1 at peak load 1EA

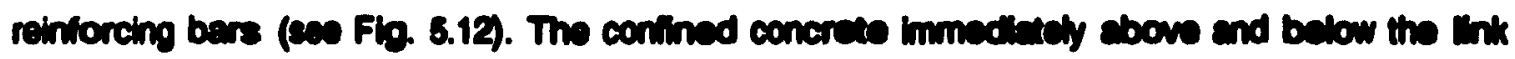
bean, however, eppecened to bo sound.

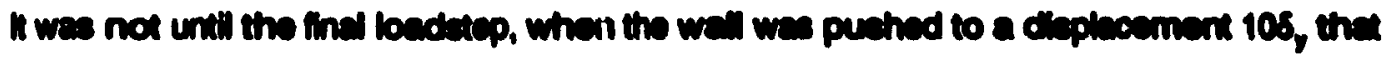

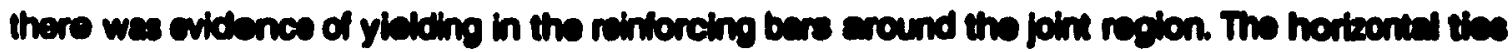

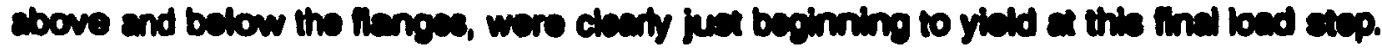

\subsubsection{Hyeteretis Respones}

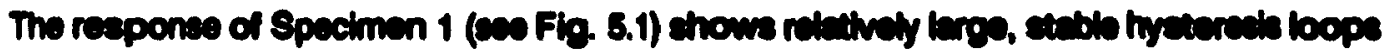
up to a ductiliny lovel of 6. The hysteredis loops cutibit soms 'pinching' es the crecks which form

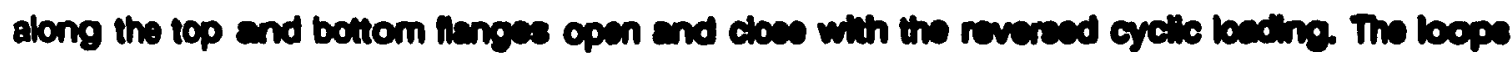

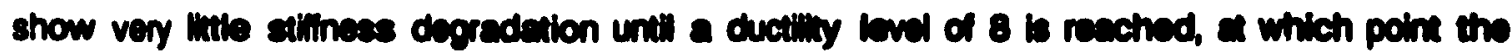
Atiliness degradetion in the loading cycles is very epparent. The peak loads for the ciaplacements a $\pm 8 \delta_{\text {, }}$ cho show noteble dacey. 


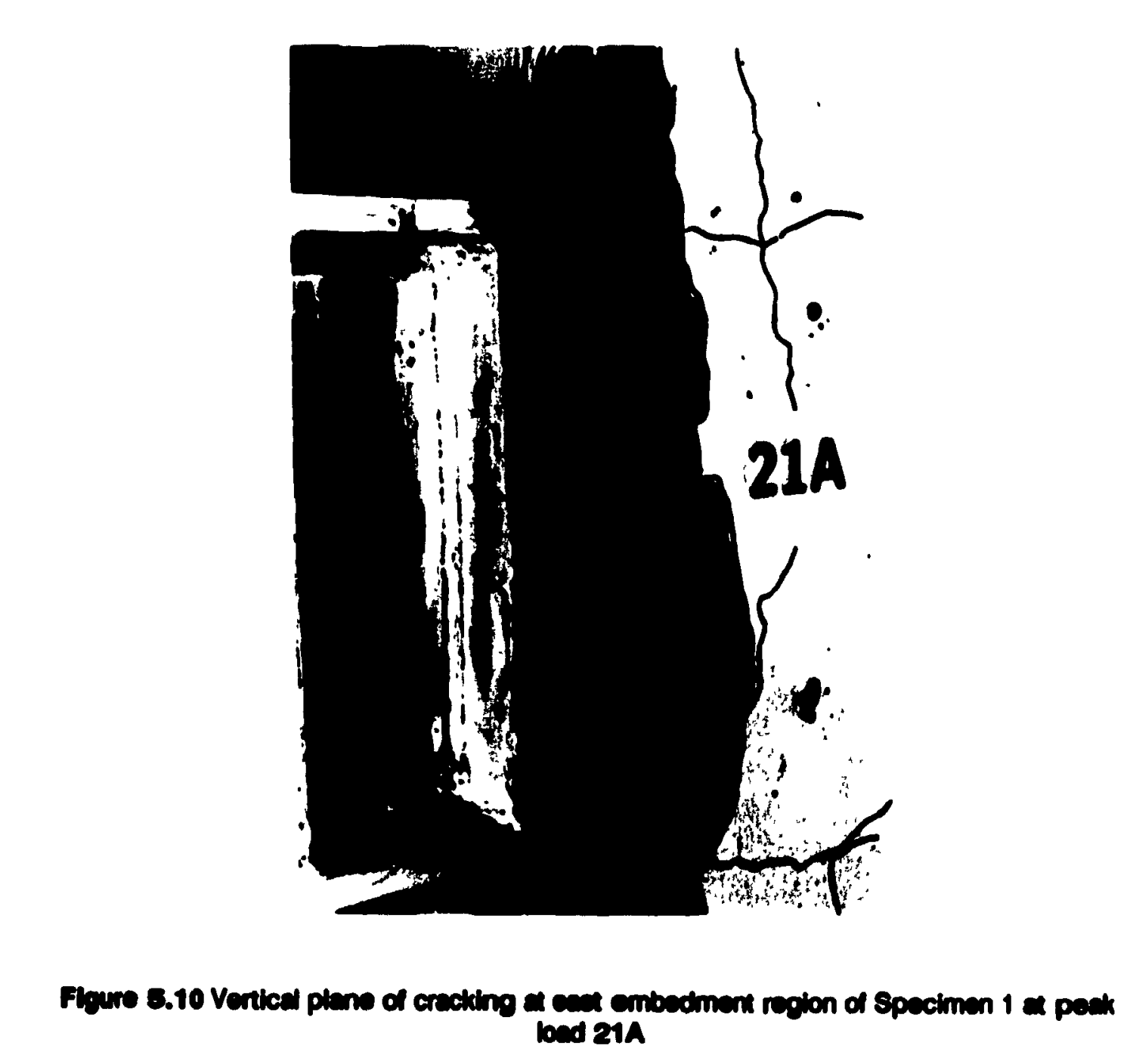




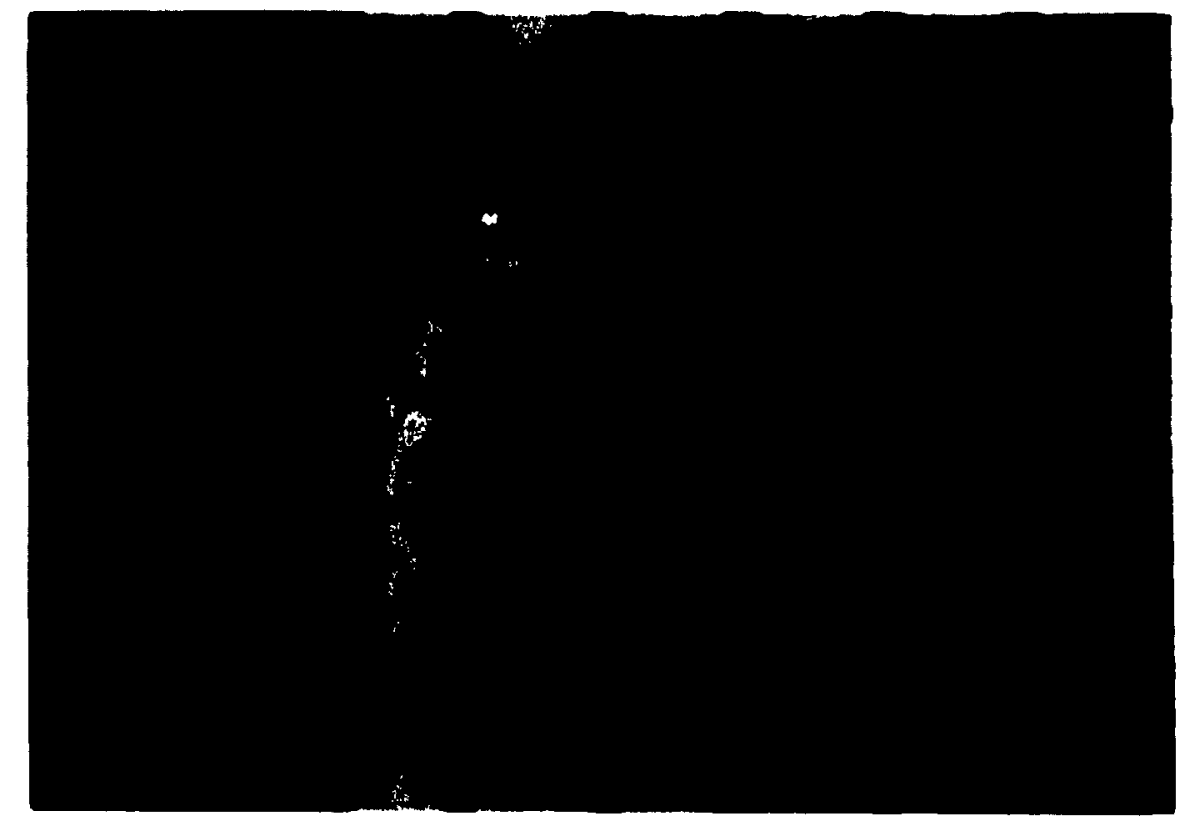

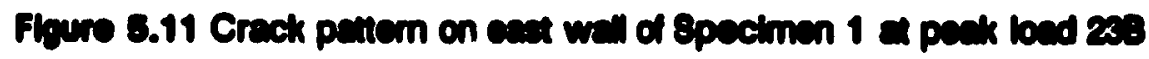


:

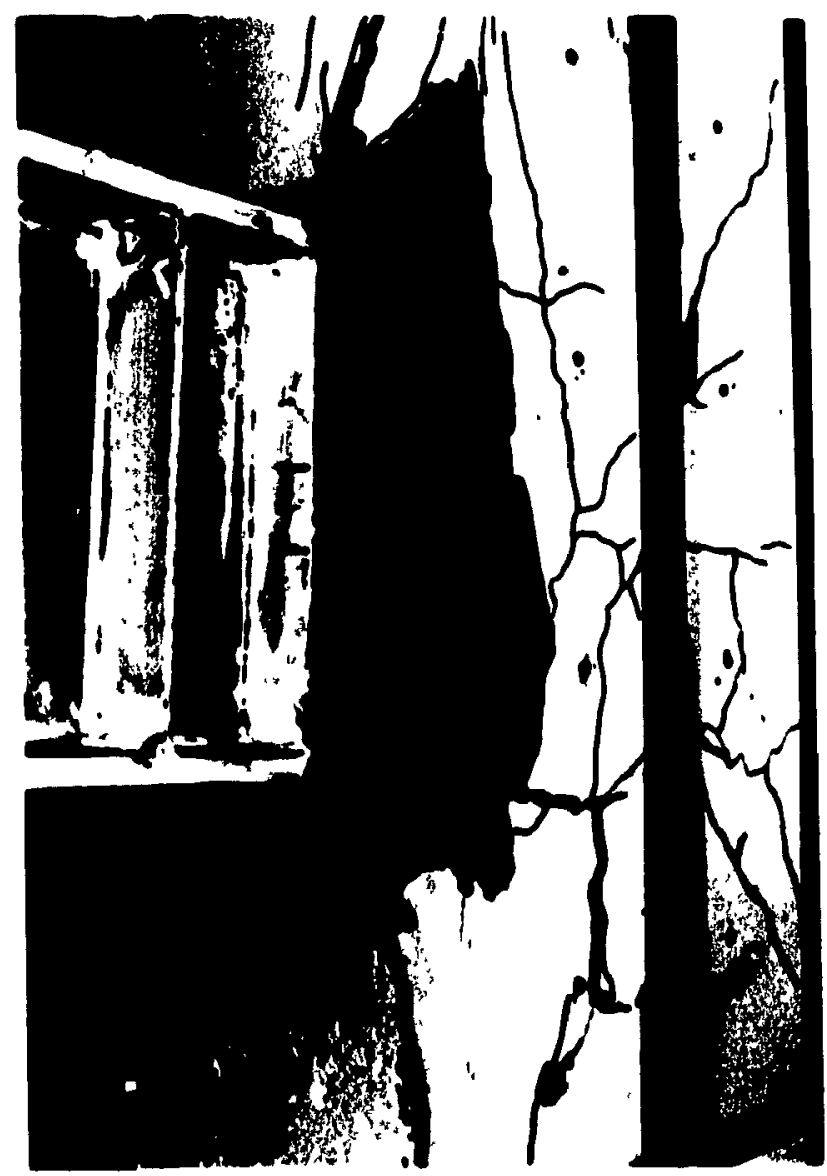

Fivere 5.12 Eaxt cmbadinent recion of Spocimen 1 a pack load 248 


\subsection{Specimen 2}

The losd-deflection response for Spacimen 2 is shown in Figure 5.13. The firet horizontal cracking in the well, at the level of the link bean tienges occurred at peak loads $4 A$ and 48 corresponding to shears of $\pm 200 \mathrm{kN}$. From strain rosette readings, the first sign of yielding of micheigh of the link bean web occurred at a load of abouk $230 \mathrm{KN}$, betore peak loed $7 \mathrm{~A}$ wes reached. From an elastic enabysis, besed on the measured yiald atreas of the web material, the predicted shaer yiold is $262 \mathrm{kN}$.

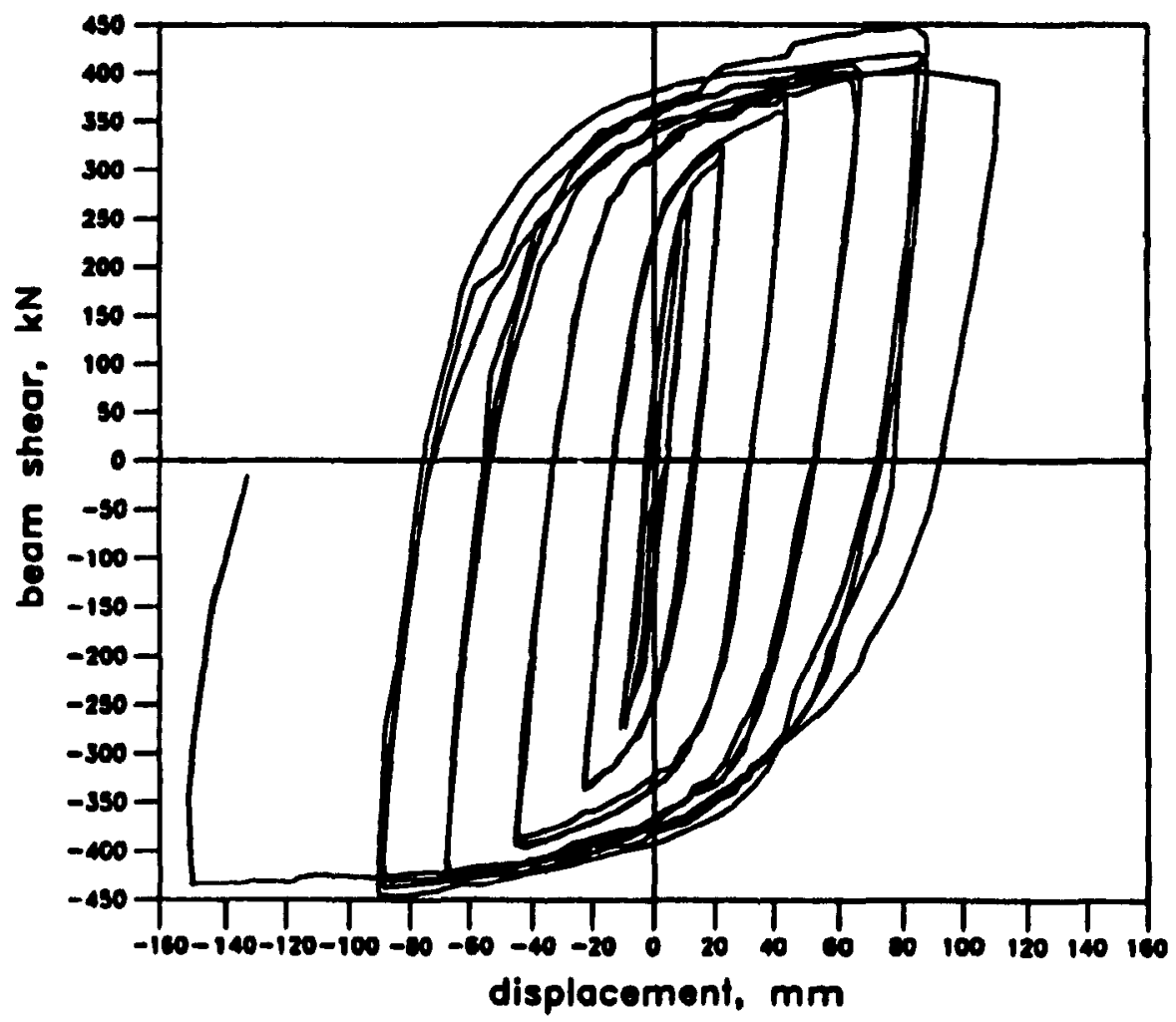

Figure 8.13 Lnk beem shear versus reletwe vericel displecement of Specimen 2

Coneral yiblding of the link beem web occurred at peak load 7A, at a lond of $274 \mathrm{kN}$ and a vertical displacement of $11.2 \mathrm{~mm}$. At this point, the whilewech on the link beem wob begen to flake and there was a alonificant drop in the stiliness of the load-defloction reaponse. Cenorel yiekding in the negative direction occurred at peak bed 7B, at a loed of $-274 \mathrm{kN}$ and a displacement of $-9.8 \mathrm{~mm}$. The predicted yielding shoer wes $\pm 275 \mathrm{kN}$. The peak displecement, $\delta_{p}$ at general yielding was taken as $\pm 11 \mathrm{~mm}$. 
Moximem shears were recorded at pack loads 198 and $21 \mathrm{~A}$, with velues of $446 \mathrm{WN}$ and

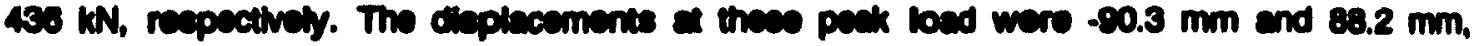
respectively, comesponding to sbout $\pm 8 \delta_{y}$. The predicted velus for the unimate shoer force wes

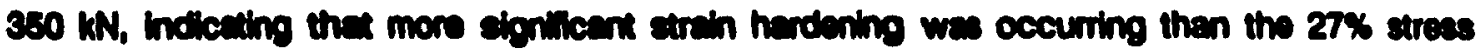
inorease sacumed over generd yieloing.

Arier pack load 218 some reduction in etifinces in the loed-delloction reaponse was

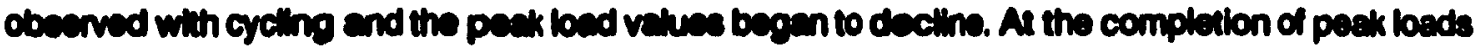

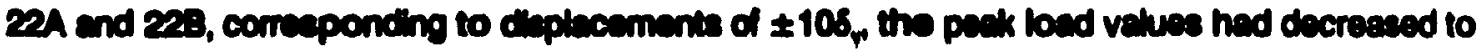

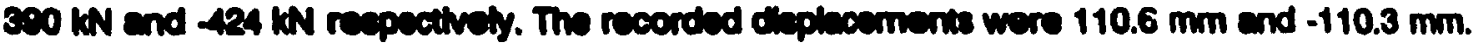

To end the tecting, the epecimen wes loaded monotonicaly in the negative direction to

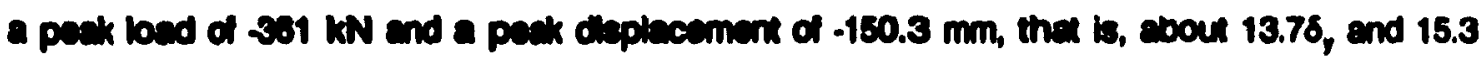
innes the ectud dieplacament et generd yiblding in the negative direction. As with Specimen 1 ,

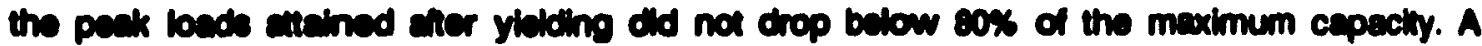
photograph of Epecisnen 2, etier texting b shown in Fig. 8.14.

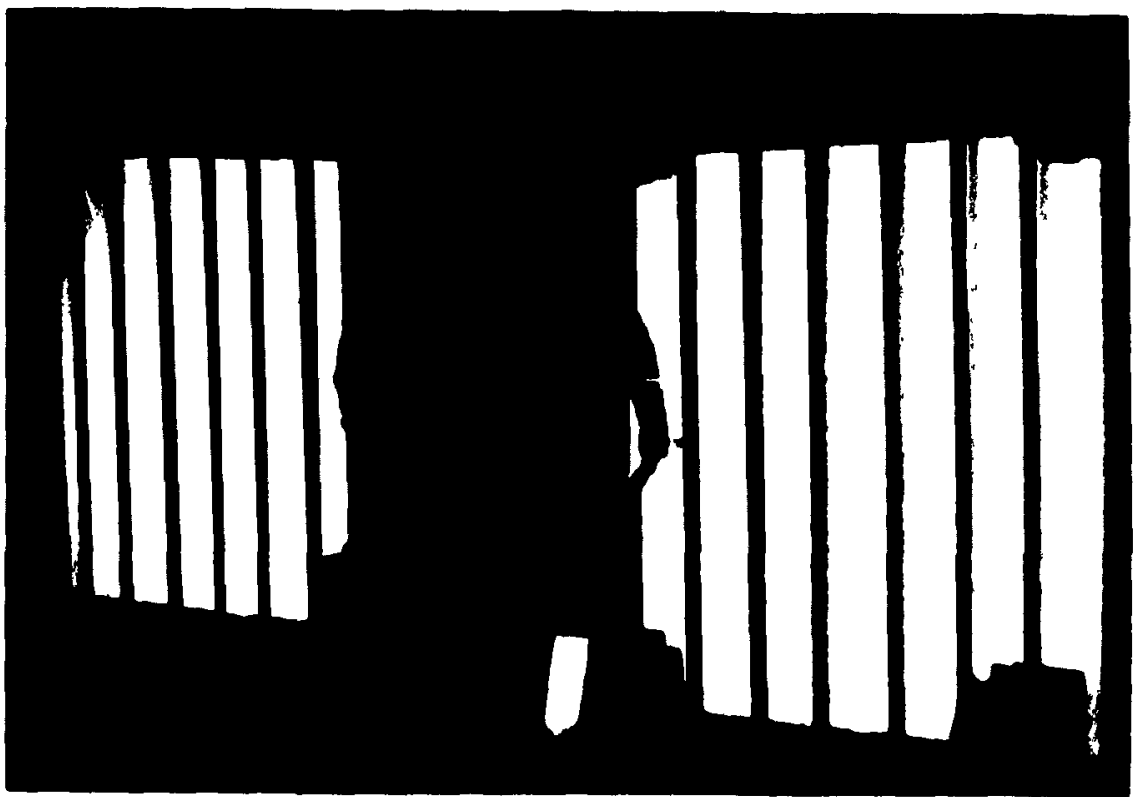

Fivers 6.14 Epocimen 2, ener teeting

\subsubsection{Unis Dann Recopenco}

The ink beam patormed vey much es prodicted a yield and wes found to hive

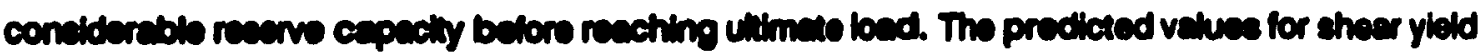

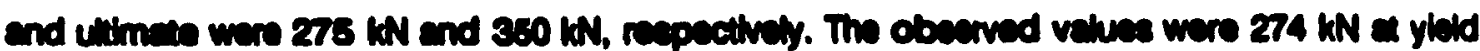

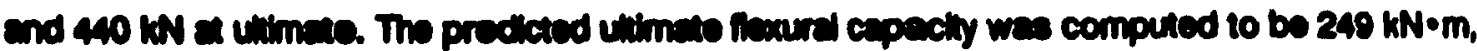


correaponding to an epplied sheer forcs over $415 \mathrm{kN}$ over ths $1200 \mathrm{~mm}$ cheer epen. The firet signe

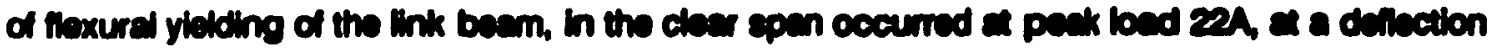

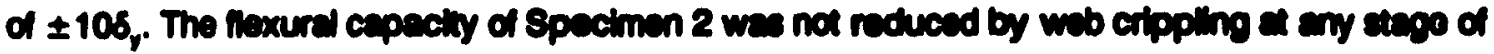
the test.

The reletwely high concrete etrength and the thicker ink baen web in the embedment resulted in very emall rotetions of the cmbedment region. As can bo seen in Fige. 5.14 and 5.15 significant shear deformetions can be esen over the clem spen of the link been.

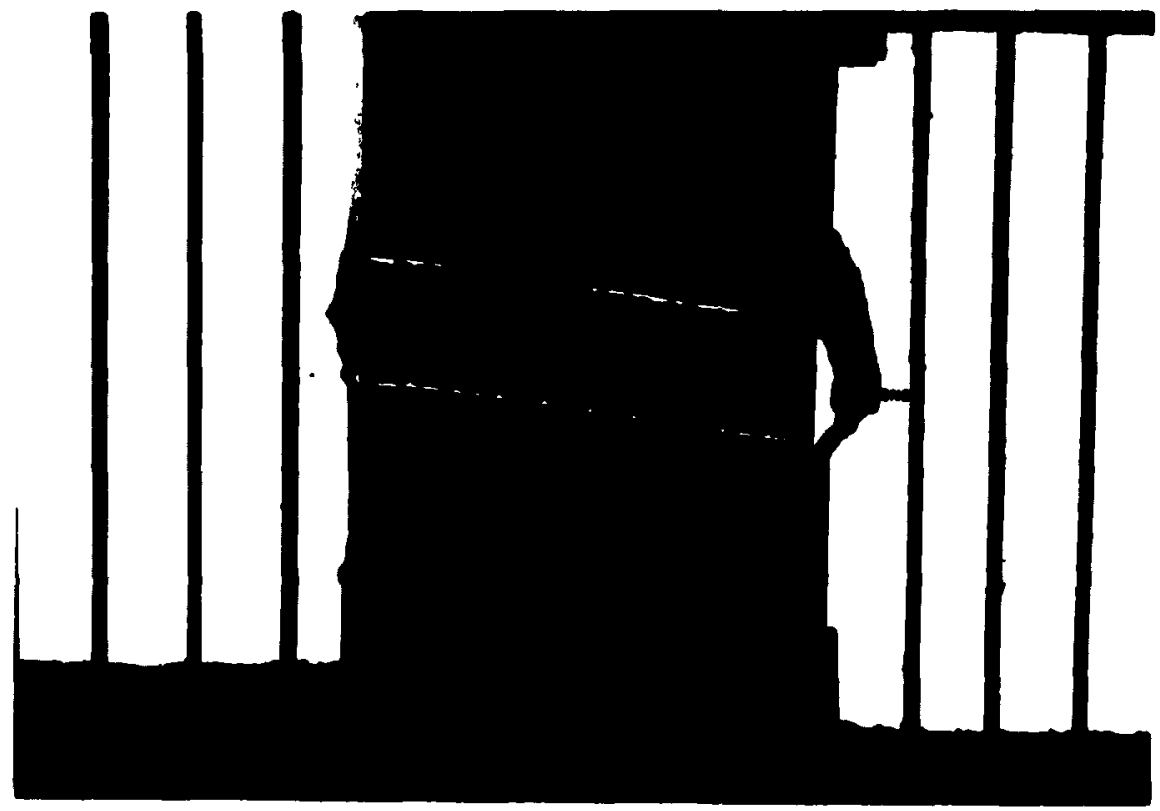

Floure 5.15 Overall view of link basm of Specimen 2 at and of tewing showing severe wob buaking

Wob buckling in the char spen was firt obeenved a peak load 183, and became more

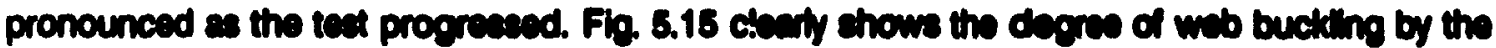

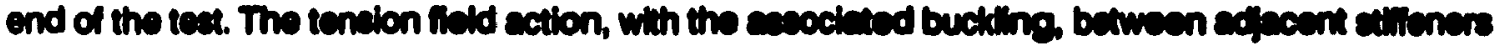
is evident. The shoer dietreses in the linit beam wes more pronounced by peak load 218 whon the

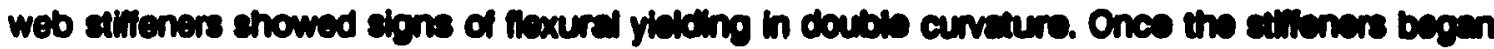
to yield, some twiating of both fienges was observed, enthough this did not progrese to the point of inducing ftenge bucking.

The concrete cover at the inner face of both walls had epelind ofl by peak load $21 \mathrm{~A}$,

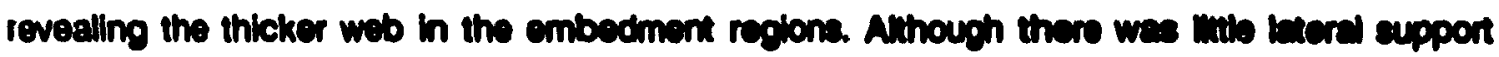
provided by the concrete for the embedded webs, no cvidences of yiliding was obearved in this

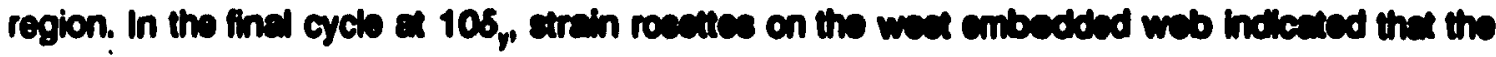
wob had yilided. Figure 6.16 shows the shear verase shear strin respones for the wabs of both 
embedments. The predicted steer yield for the cmbedded whbs is $419 \mathrm{kN}$. The comesponding

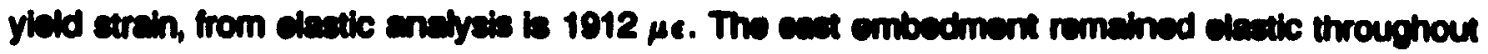
the teat. Figure 6.17 shows en overell viow of the link beam afer removel from the walle.

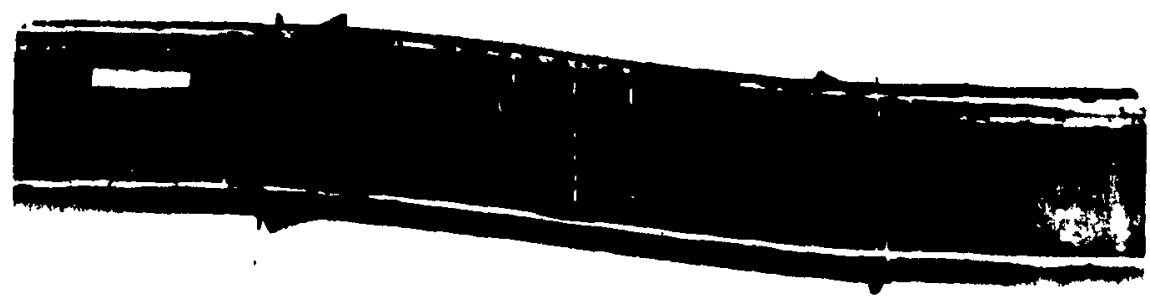

Fivere 8.17 Overall view of link bean of Epccinen 2 eiter removel from the wails

\subsubsection{Relwerced Conereto Reopones}

The firet evidence of crocking in the well wes observed at poak beds AA and 4B, an an applied shear on the lin'k beam of $\pm 200 \mathrm{kN}$. Horkonkel cracks located a tho intertace between the link beam nenges and tho concrete, extended from the flange scroses the inner fece of the wall to the side frcese of the walls (cee Fig. 5.18).

Further crecking recuited in the spaling of a semi-ciroular block of concrete at the inner face of each well. Fioure 5.19 show the crecking of the ease cmbeckment region a poek bed 168. As londefep 18A, further speming occurred revereling the well confined concrete of the well and the sound concrete confined between the link baem flengos. Figure 5.20 shows the delamination between the link bean and the surrounding concrete due to their relettve movements.

Tho finct vertical crecks eppeared a pack load $8 \mathrm{~A}$, an en eppliad sheer in the link bean of $275 \mathrm{kN}$. Ths crecks were loceled 480 end $325 \mathrm{~mm}$ from tho inner fece of the ceat well and 730 and $445 \mathrm{~mm}$ from the fros of the weat wel. Verticel and incined crecks, delineeting the direction of principel compreashe streases, were obsenved on the caet well at an applied shoer in the link beem of $397 \mathrm{kN}$ at losdatep 128. Similer crecks mere observed on the weet well at an epplied shear in the link beem of $388 \mathrm{kN}$ a peak load 13A. The creck pentern on the eact and west walls

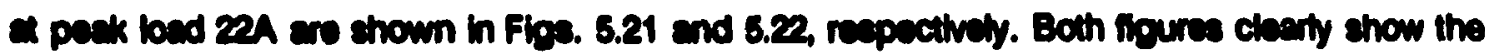
cracks following the direction of principel compresetwe etresese from the bstion fienge of the embedment to the loading beams. Similer cracking is epperent extending up from the top fienge 

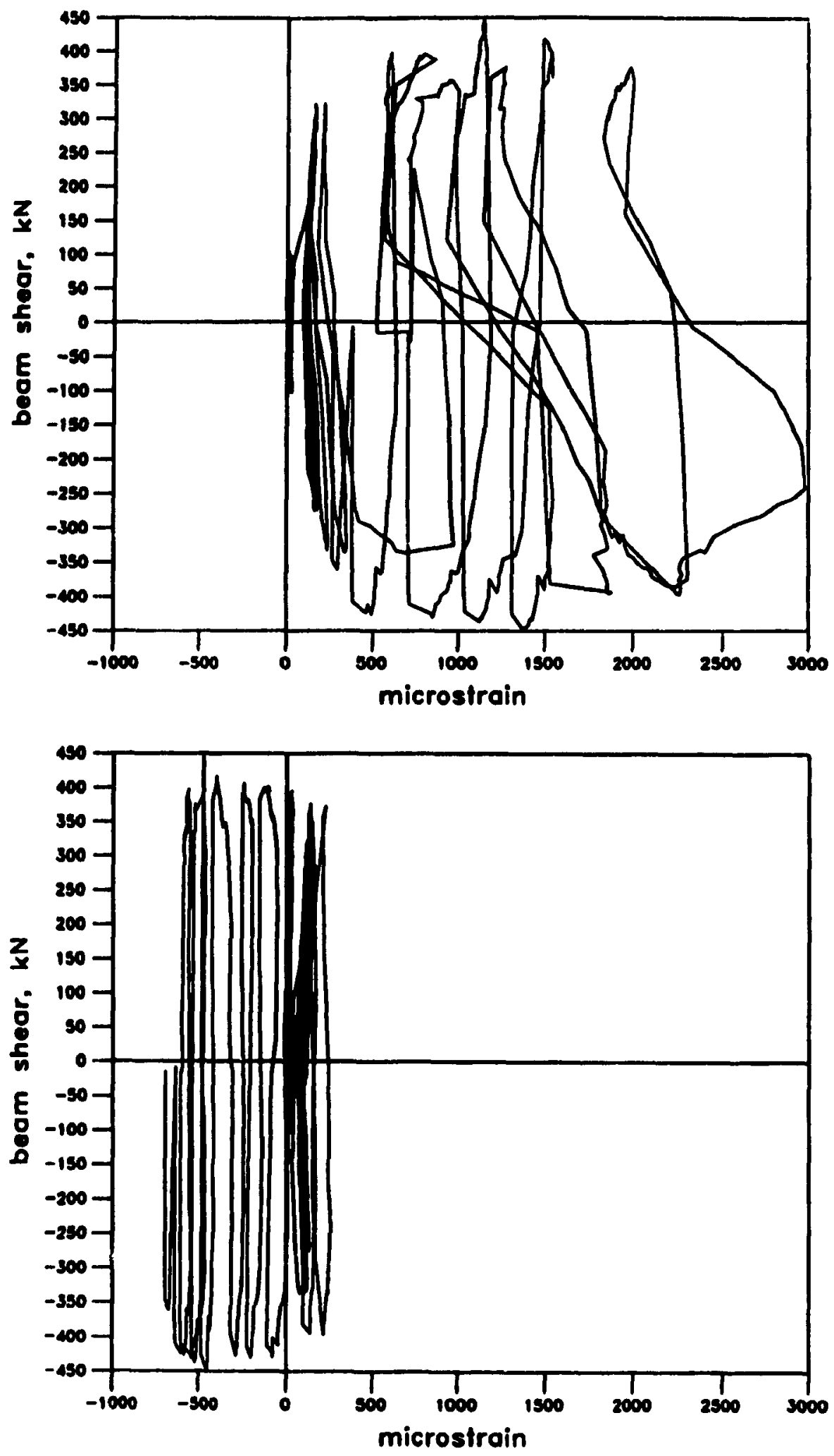

Figure 8.16 Shear versus shear strain responses of cant (top) and west (botiom) embedded web regions of Specimen 2 


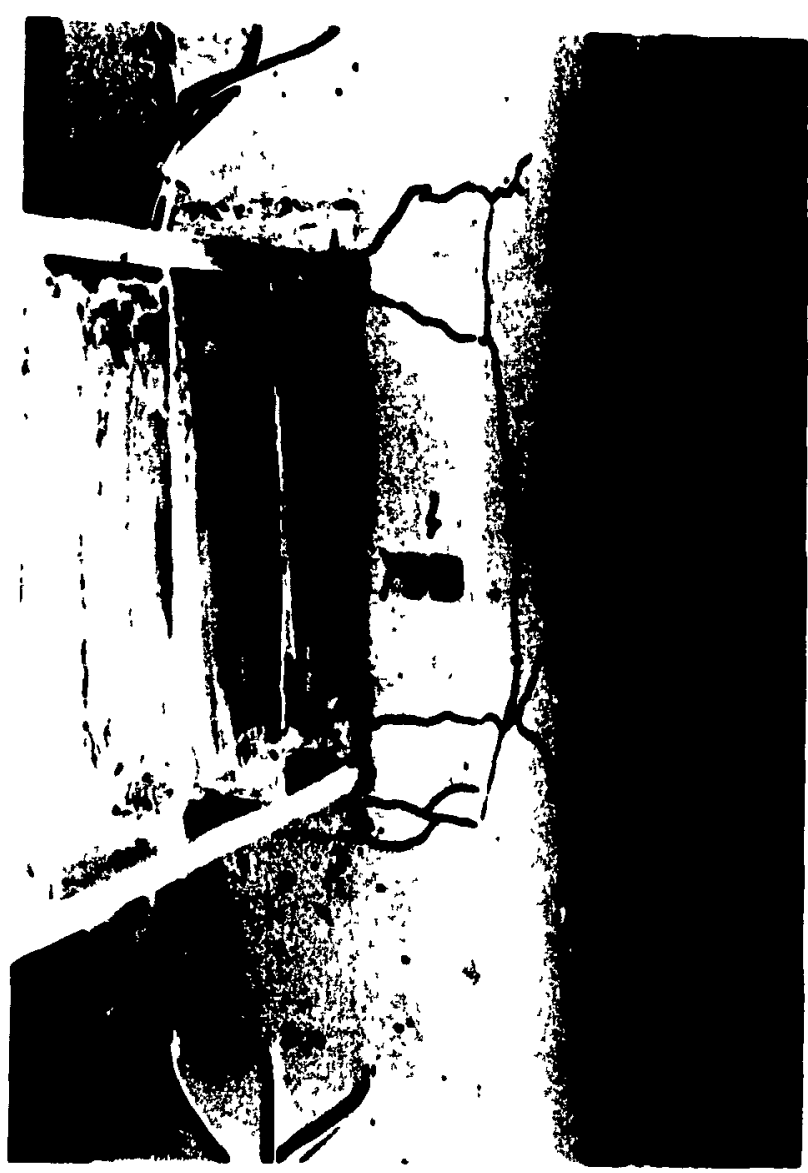

Firure 8.10 Eext embodment region of Epceimen 2 at peak loed 83

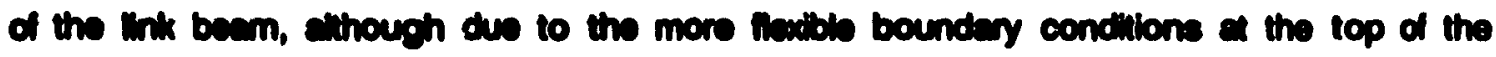
epecinon, this peatem is lase pronounced.

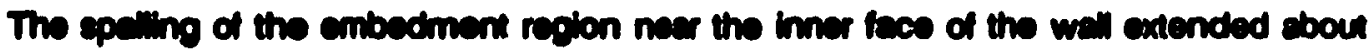

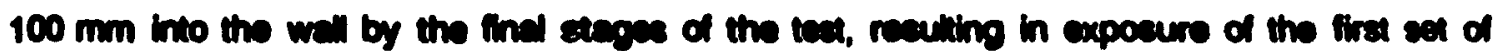

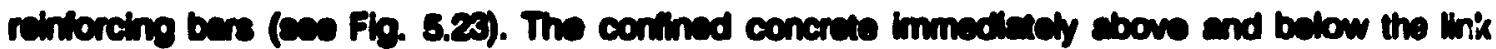
bean, however, epposend to be sound. 


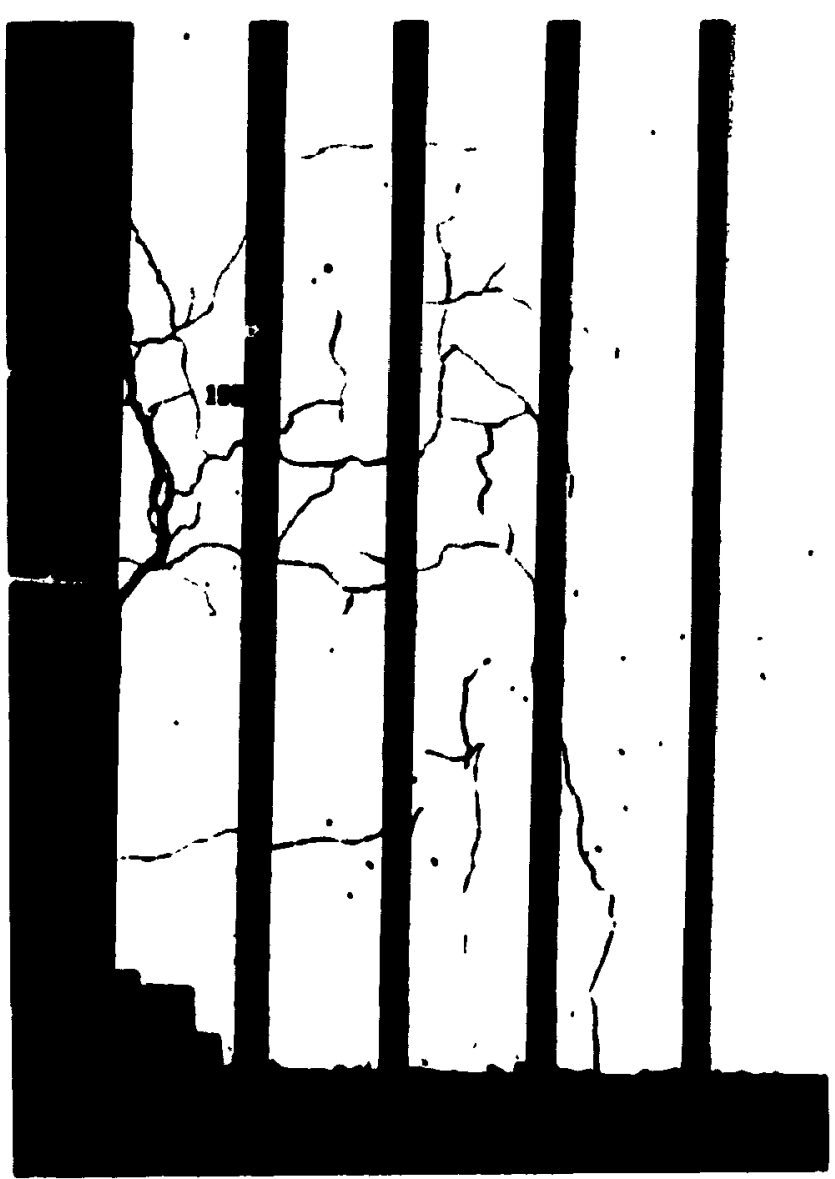

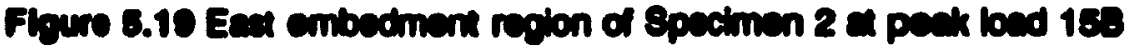

\subsubsection{Aypterctic Recpones}

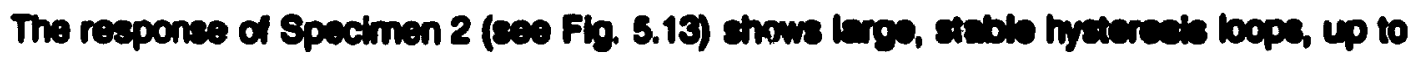

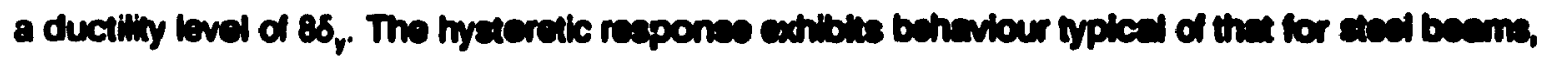

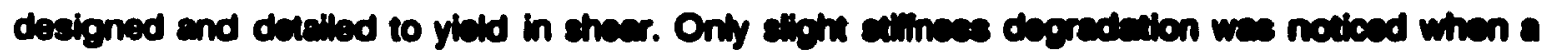

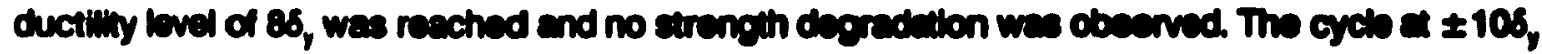

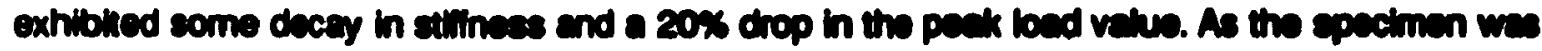

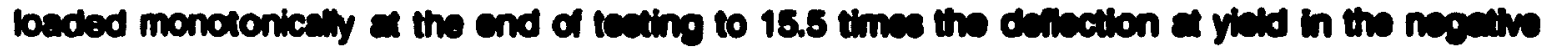

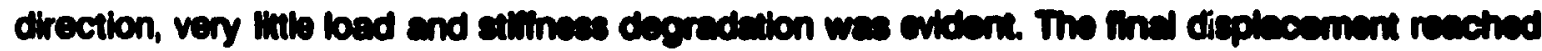
was $-150 \mathrm{~mm}$. 


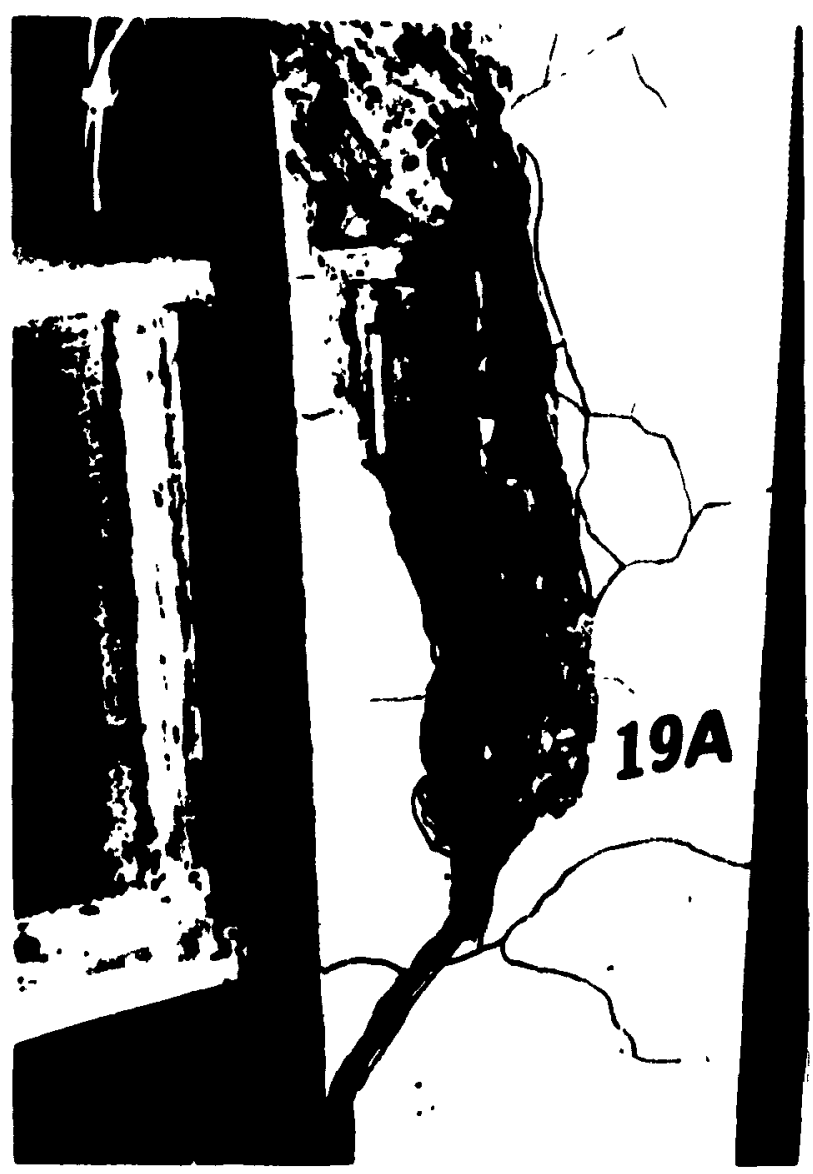

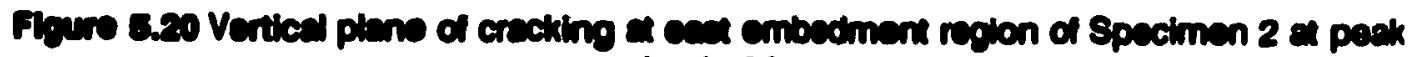
lond 18A

I 


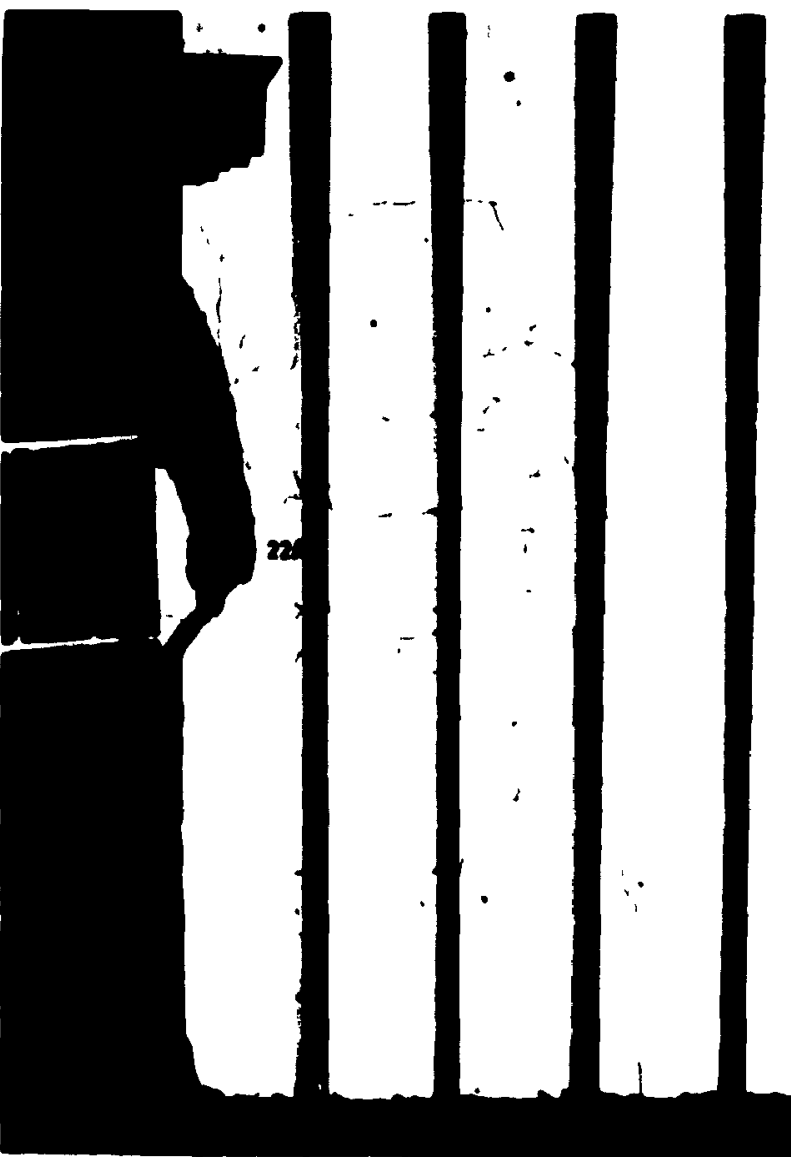

Fivure 5.21 Crack pattern on east well of Spacinen 2 at paek lond $22 A$ 
1

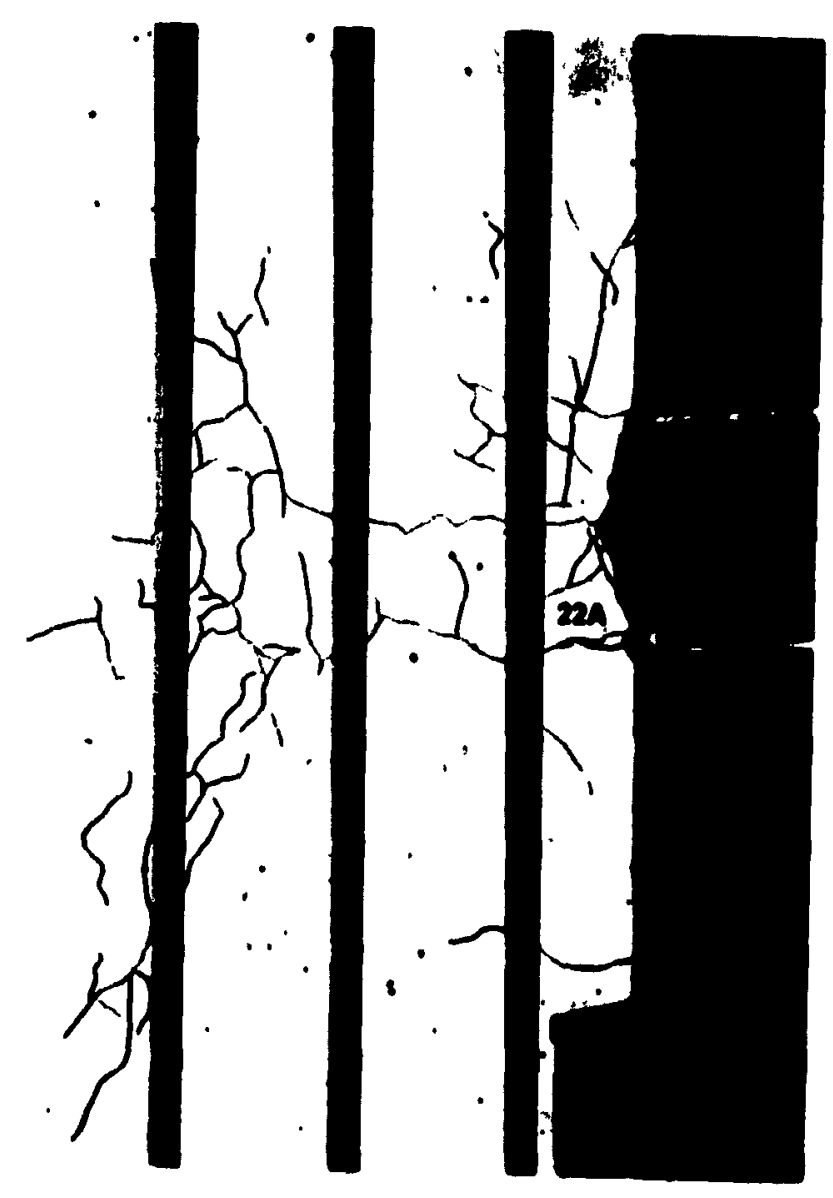

Fivere 8.22 Crack patem on wext well of Spectinen 2 at paek bed 22 A 


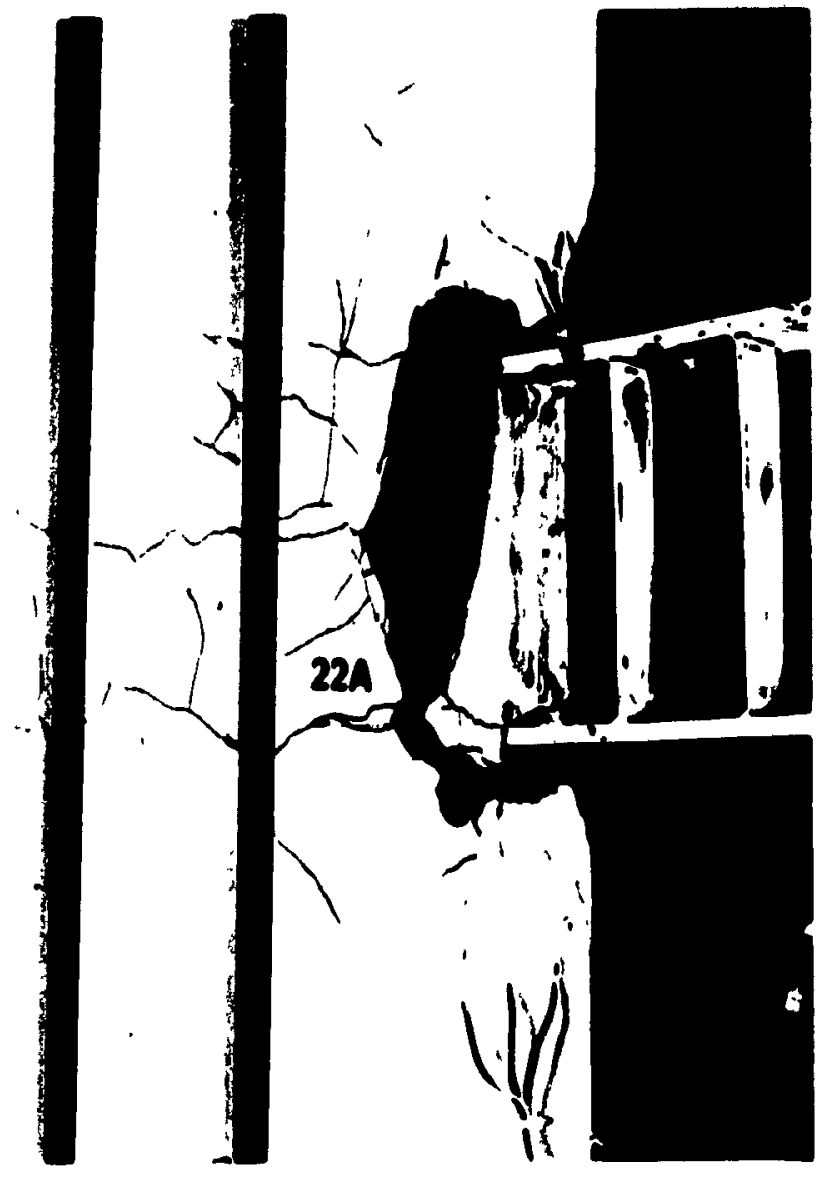

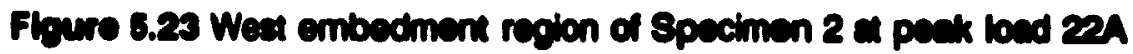




\section{Chapter 6 \\ Comparison of the Responses \\ of Specimens 1 and 2}

\subsection{Comparison of Predicted and Exporimental Valuce}

Teble 6.1 compares the shears corresponding to the key boheviourd events for Specimens 1 and 2. The calculations for the precicted values are given in Appendix $\mathbf{A}$. The predicted velues for both specimens were celculeted uing tho refined dacion epprosch preaented in Section 3.1 which sccounts for the eflect of epaling of the conerite cover. This cover spelling gives rbe to en increase in the clear span of the link been and a decrease in the embedment lengths of the link bean. $t$ is noted that the link bean of Spocimen 2 had a lower yibld atreas and a alighty thinner web in the clear spen region. The difierence in predicted strencthe of the reinforced concrete embedments is due to the sionificent divierence in concrete strength (25.9 and 43.1 MPa, for Specimens 1 and 2, respectively). The measured cross. sectionsl dimensions are ofven in Appendix A. The mescured material propertios are given in Section 3.3.

As can be seen from Table 6.1, the predicted fallure mode of Specimen 1 egrees well with the obsenved fallure mode. This specimen, however, exhibhed significen yielding of the embedded wob as well as web crippling in the region of cover spalling. Refinements to the desion procedure reasted in improved performence of Specimen 2 with thell shear yilding occurring in the exposed link beam whinout signilicant distress of the link beam in the embedded region. The procedure for the decion of the reinforced concrete embedment region was adepted to include the eflects of cover spalling and provide reinforcement cepable of controling the fienge-concrete interfece gep. The responses of both specimens demonatrefed that the design of the reinforced concrete embedded region was edequate to develop the necessery cepecily and control the gap openings. 


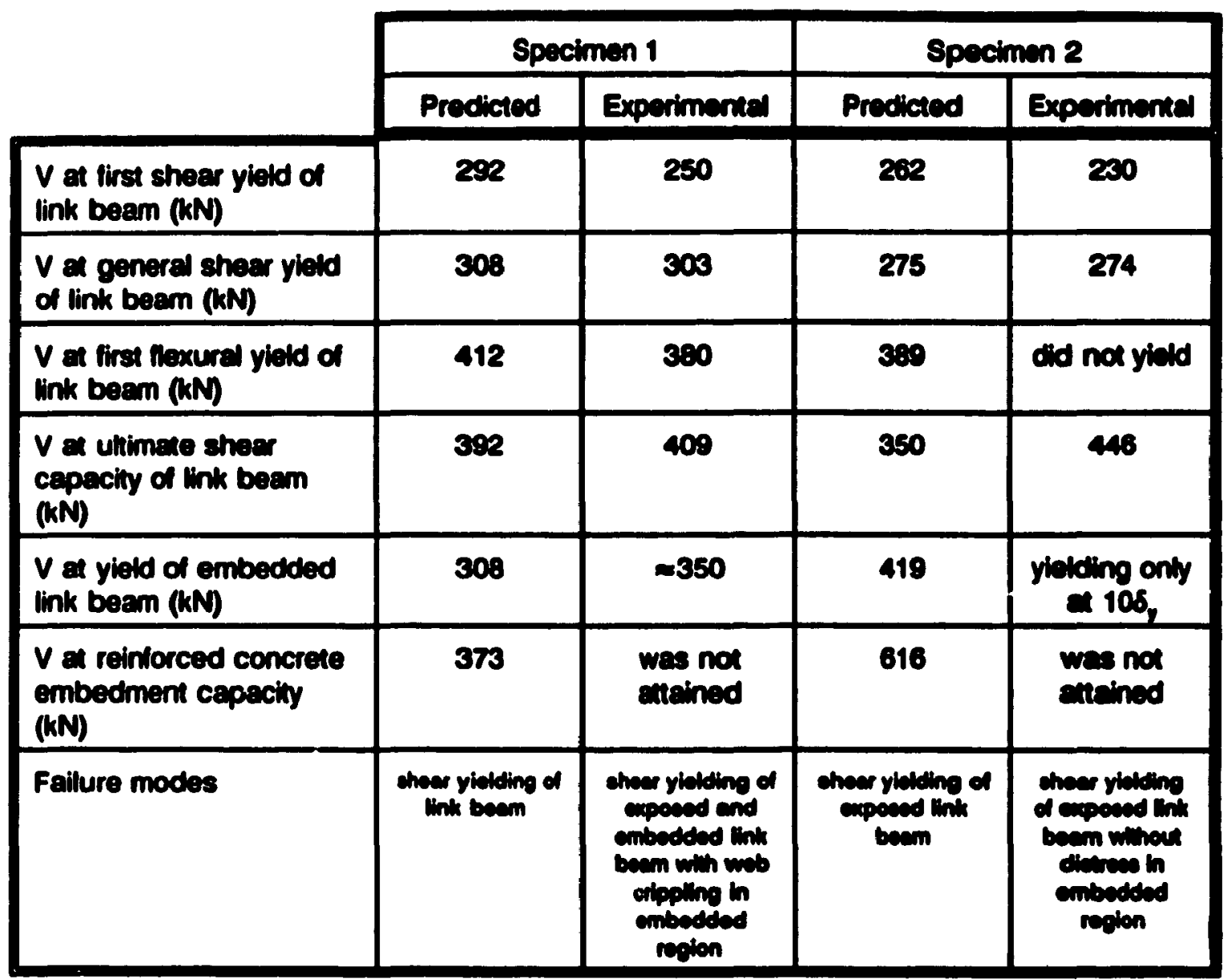

Table 8.1 Comparisons of predicted end experimenel veluse

\subsection{Hyotorotic Reaponses}

The complete hysterctic responses of Specimens 1 and 2 are shown $h$ Fig. 6.1. Both

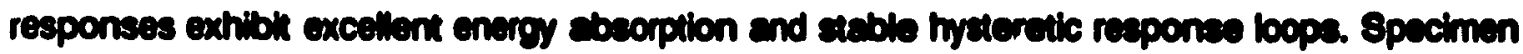
1 begine to show ovidence of 'pinching' in a displacernent of $\pm 8 \delta_{p}$ in the excond and thind

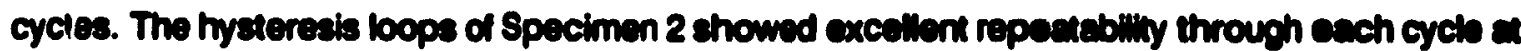
each displacement lovel with no signs of significent 'pinching'. Onty a very minor allineas decay was observed at displacements corresponding $10 \pm 86$, and $\pm 105_{r}$

The applied thear versus diaplecement envelopes a ductimy lovele of 48, and 85, are shown in Figs. 6.2 and 6.3, respecthely. The larger loops exchibited by Specimen 2 indiente then a greater amount of energy bs being dissipated than in Specimen 1. In assecaing the dilierences between the two specimens, $h$ is important to recognice that the link beam of Specimen 2 had both a marginally thinner web and a amaiker yiold stress. 

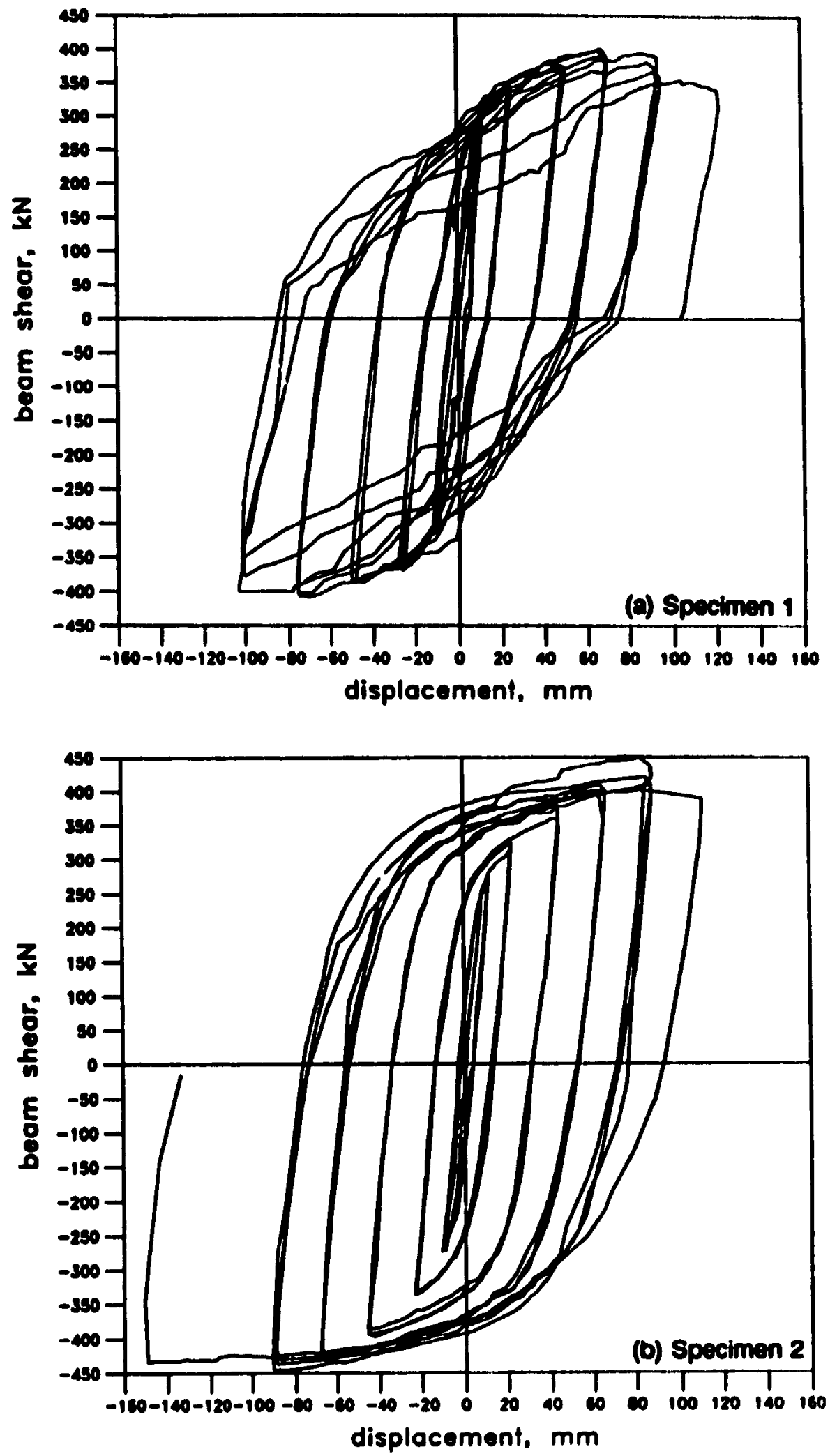

Figure 6.1 Link beam shear versus reletive displecement of Specimens 1 and 2 


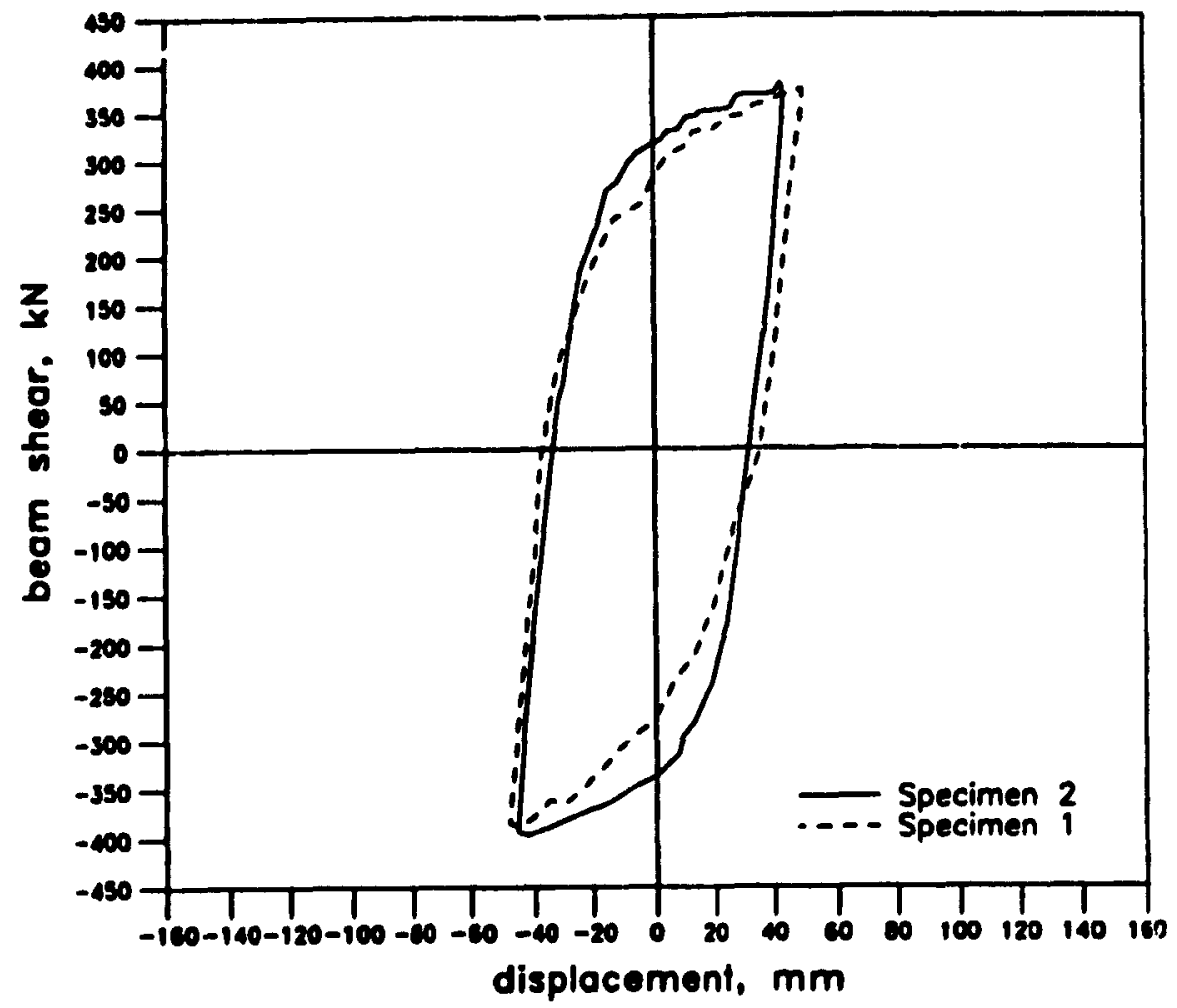

Fligure 6.2 Appliod shear vereus displecement envelope at 46,

The cumulative energy curves for both specinens are shown in Fig. 6.4. Dus to the distress of the embedded portion of the link beem, the energy sbeorting ability of Specimen 1 drops below than of Specimen 2 enter a displacomem ductimy of aboux 7. This drop in the energy dissipation is due to the 'pincting' evident in the hystereats loops and the reduction in the laed

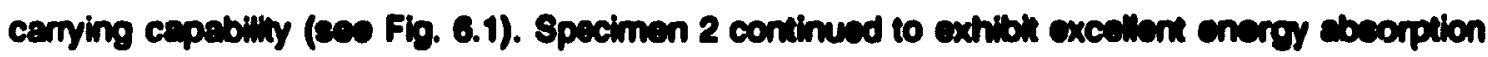
capability throughout the entike revereed cyclic loseing.

In order to quantily the overell respones of each epecimen, en equivelent eleatic damping coetlicienr, $\beta$, is used. This coeticion, $\beta$, is defined as (soe Fig. 6.5):

$$
p=\frac{A_{1}}{A_{2}} \times \frac{1}{2 \pi}
$$

where $A_{1}$ ts the area within the hystereais loop of one hall cycte, and, $A_{2}$ is the area of the triangle defined by an equivelemt eleatic atilineses to the poek load and corresponding dentection of each hall cyclo. 
to

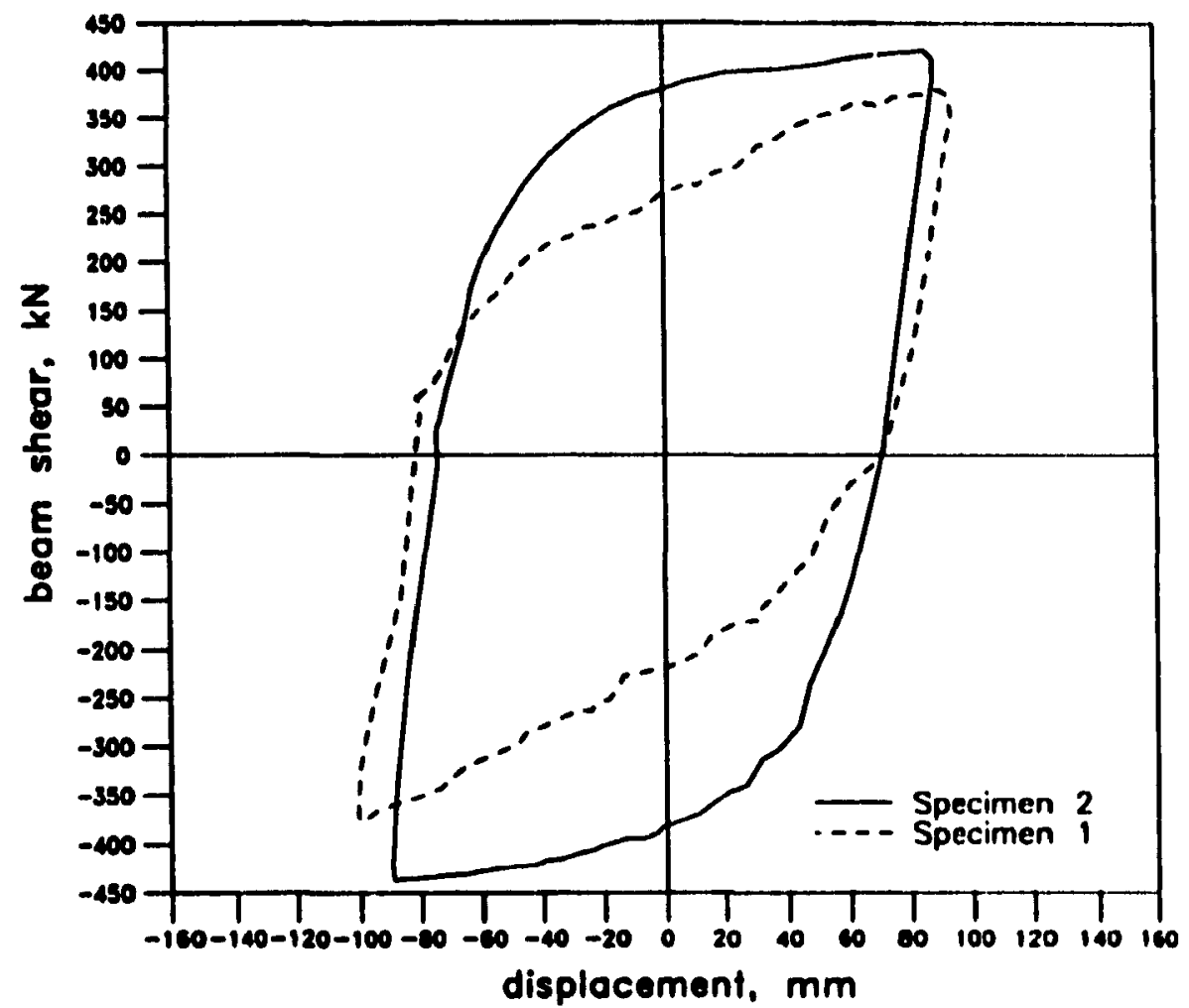

Figure 6.3 Applied shoor versus displecement envelope at 85,

The maximum value of $\beta$, representing the case of rigid-perfectly plastic hysteretic behaviour with rigid unloading response is $\frac{2}{2 \pi}=0.318=31.8 \%$. The equivalent elastic damping coeficients for each hall loop for Specimens 1 and 2 are shown in Fig 6.5.

Al each ductility level, the demping coefilicient of the first positive hall cycle ts represented by the top data point while the third negative hall cycle is the bottom data point. The width of the response band is an indication of the degree of decey of energy sbsorption cccurring with cycling at each ductility lovel. A wider bend indicates greater decay of energy absorption than a thinner band.

It clear from Fig. 6.5 that Specimen 2 exhibits a higher level of damping, and is therelore able to dissipate greater amounts of energy. $1 \mathrm{t}$ can also be seen that the response of Specimen 1 exhibits significamty greater decey beyond a displacement ductility level of 4. 


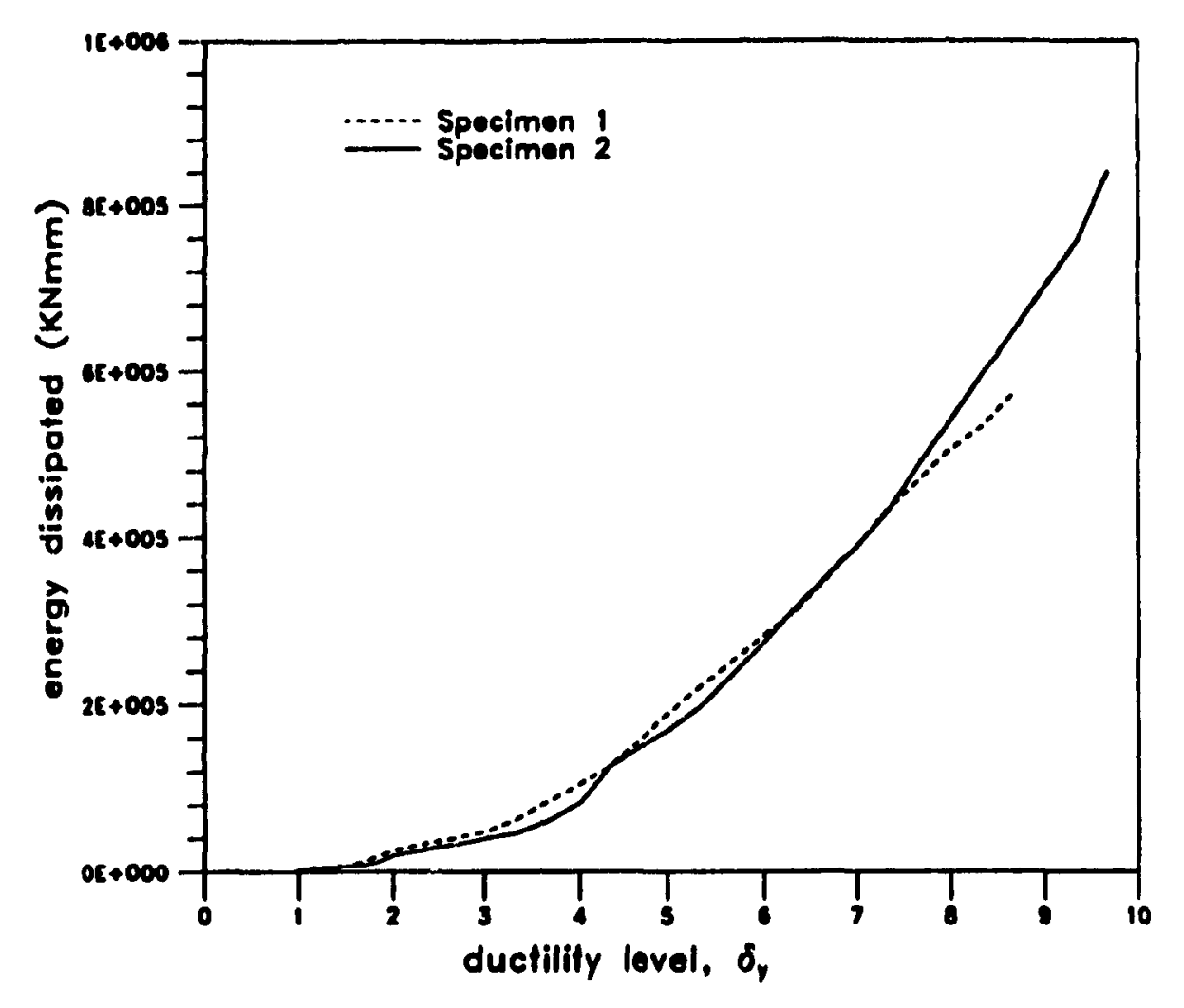

Figure 6.4 Cumulative energy disclpation of Specimens 1 and 2

\subsection{Reaponse of the Link Beams}

Alhough Specimen 1 exhibihed excellent response charecteriatics up to a displecement ductility of abour 6, severe wob crippling occurring in the embedded region (see Section 5.1.1). reduced both the shear and moment capscily of the link beam at the spalled fece of the wall. The refinements to the design for Specimen 2 (eee Section 3.1.4.) were en attempt to control this failure mechanism.

It was clear that the embedded regions of Specimen 2 behaved as deaired, with the steel embedment remaining elastic while the link beem experienced algnilicent deformations over its clear span. Since the crippling of the embedded link beam had been controlled, the embedment region experienced very little distreas and the behaviour approaches that of a ductile link bean in an eccentrically braced frame (Engelhardt and Popov, 1989). These design and detalling refinements resulted in virtually rectangular, hysteresis loops which remained atable up to very high ductilities and excellent energy absorption. When web crippling is controlled, there are two 


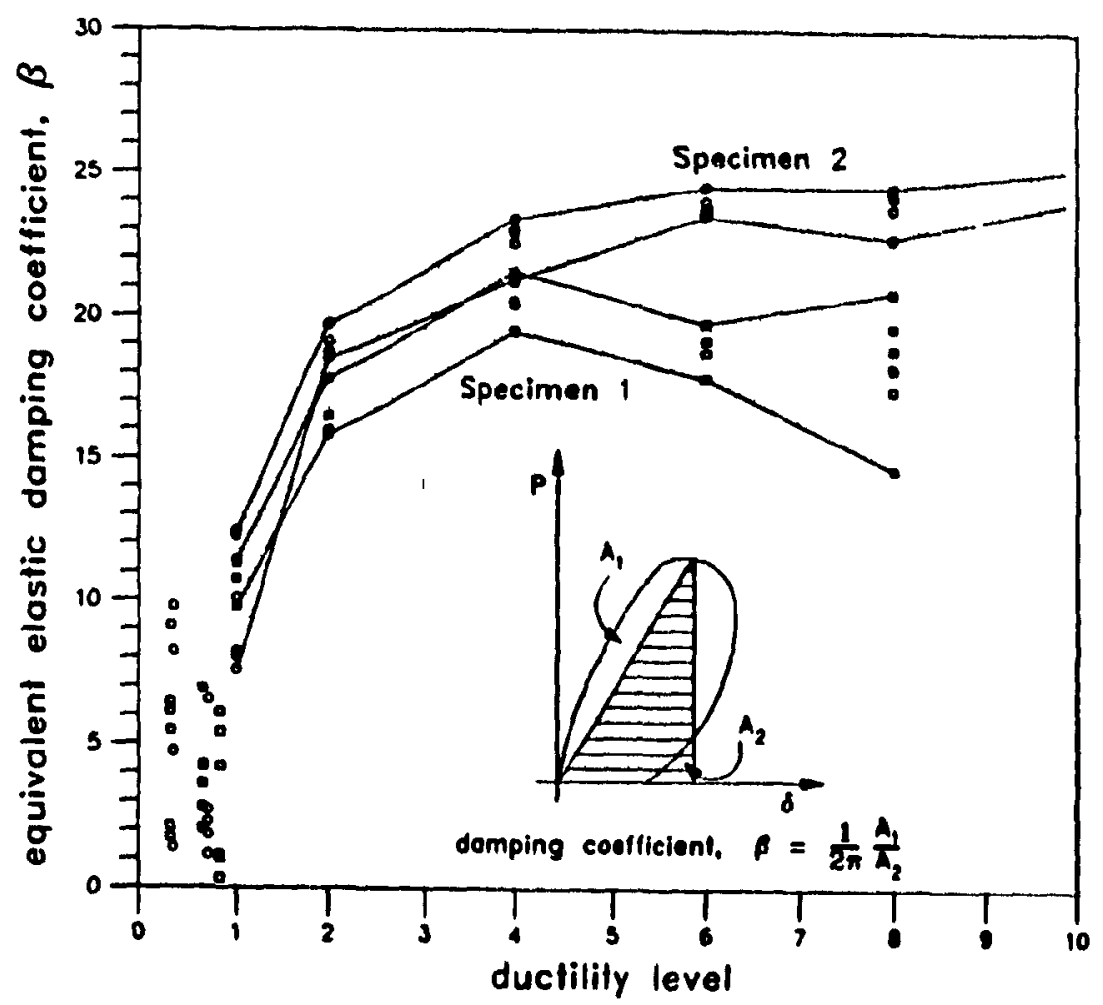

Floure 6.5 Equivalent elastic damping coeticients for Specimens 1 and 2

potential controiling modes of fallure; ether the web of the link beem will teer as a reacin of low cycle fatioue or the link beam will buckle laterally. There was no evidence of ether of these triture modes in Specimen 2. Figure 6.6 shows the link beams of Specimen 1 (top) and 2 (bottom) alier removel from the walls. The crippling of the embedment region of Specimen 1 is very apparenk. It can be seen that the only distress to the link beam of Specimen 2 occurred in the clear apan.

\subsection{Respones of the Rolnforced Conerete Embedment Reglons}

The strains in the longitudinal reinforcing steel near the face of the walls in the reinforced concrete embedment regions of Specimens 1 and 2, are illustrated in Fig. 6.7. Before bading, the vertical reinforcemem of both specimens exhibined a small compressive strain due to the posttensioning of the walls to simulate gravity loading. It can be seen that this longitudinal steet does not yiald (vield strain = 2000 microstrein) in either wall, indicating that the steel provided served 

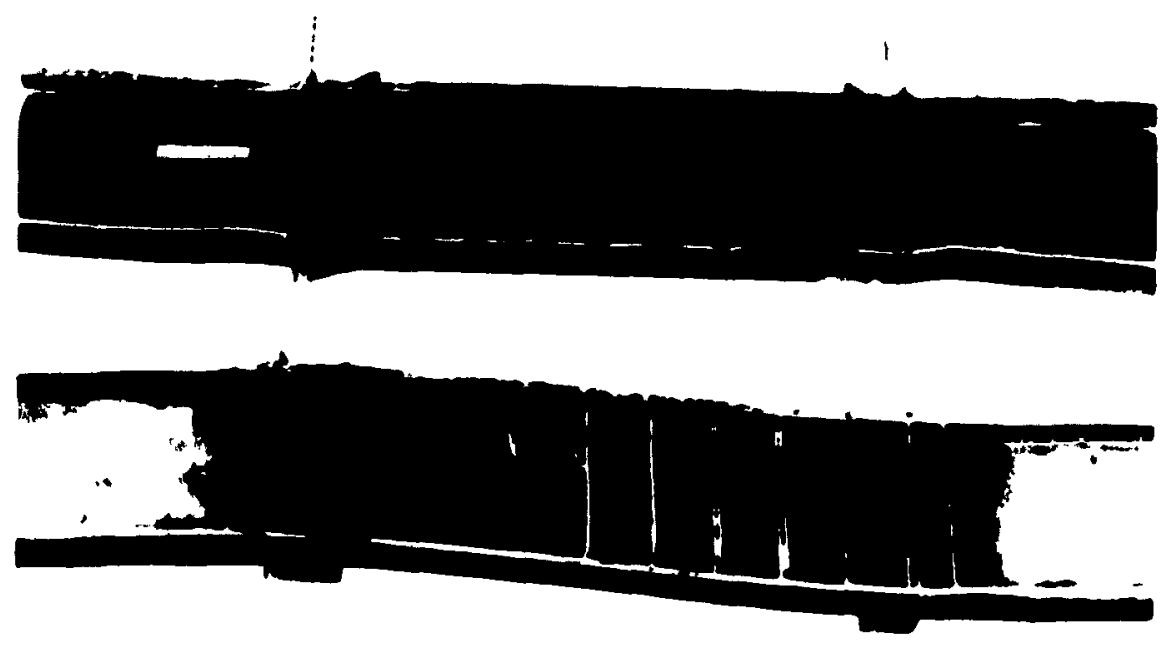

Figure 6.6 Link beams of Specimen 1 (fop) and 2 (bottom) enter removal from the wrins

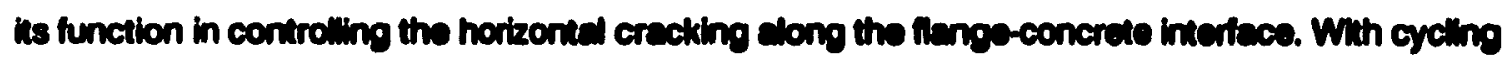

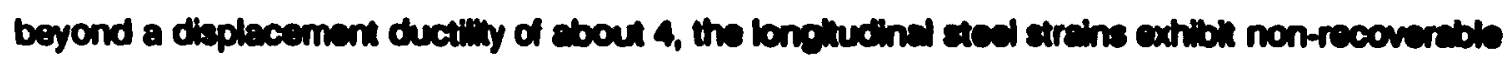

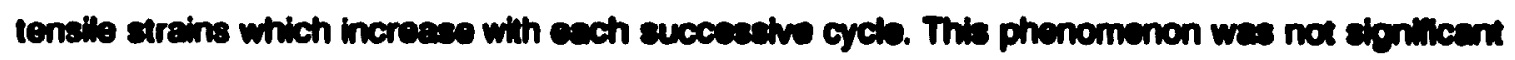
in Specimen 2 (eee Fig. 6.7(b)). Throughout the entise respones, the horizontel crack at the fiengeconcrete interfece of Specimen 2, openod and completely cloced with cycing. On the other hand, the embedded ponion of the link beem of Specimen 1 cxperienced web cripping in the recion of the longitudinal reintorcempent. Because of this mb cripping the embedded linik beem low a

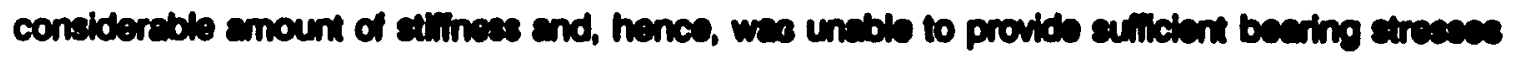
to completely close the crack.

\subsection{Displacement Contributions of the Embedmesta Rogions}

It is clear from the hyeterctic response of the syetem end from the reletwe lack of dietreses to the reinforced concrete embedment, that the behwiour of the coupled syatem is domincted by the response of the link basm. Figure 6.8 shows the contribution of the displecements of the link beam to the totel reletwe displecements of the walls for Specinene 1 and 2. The deaned ins on each figure represents the reletwe displecements of the ends of the link beams white the solid line represents the total relative displacements of the walls. For Specimen 1 up to a dieplacement 

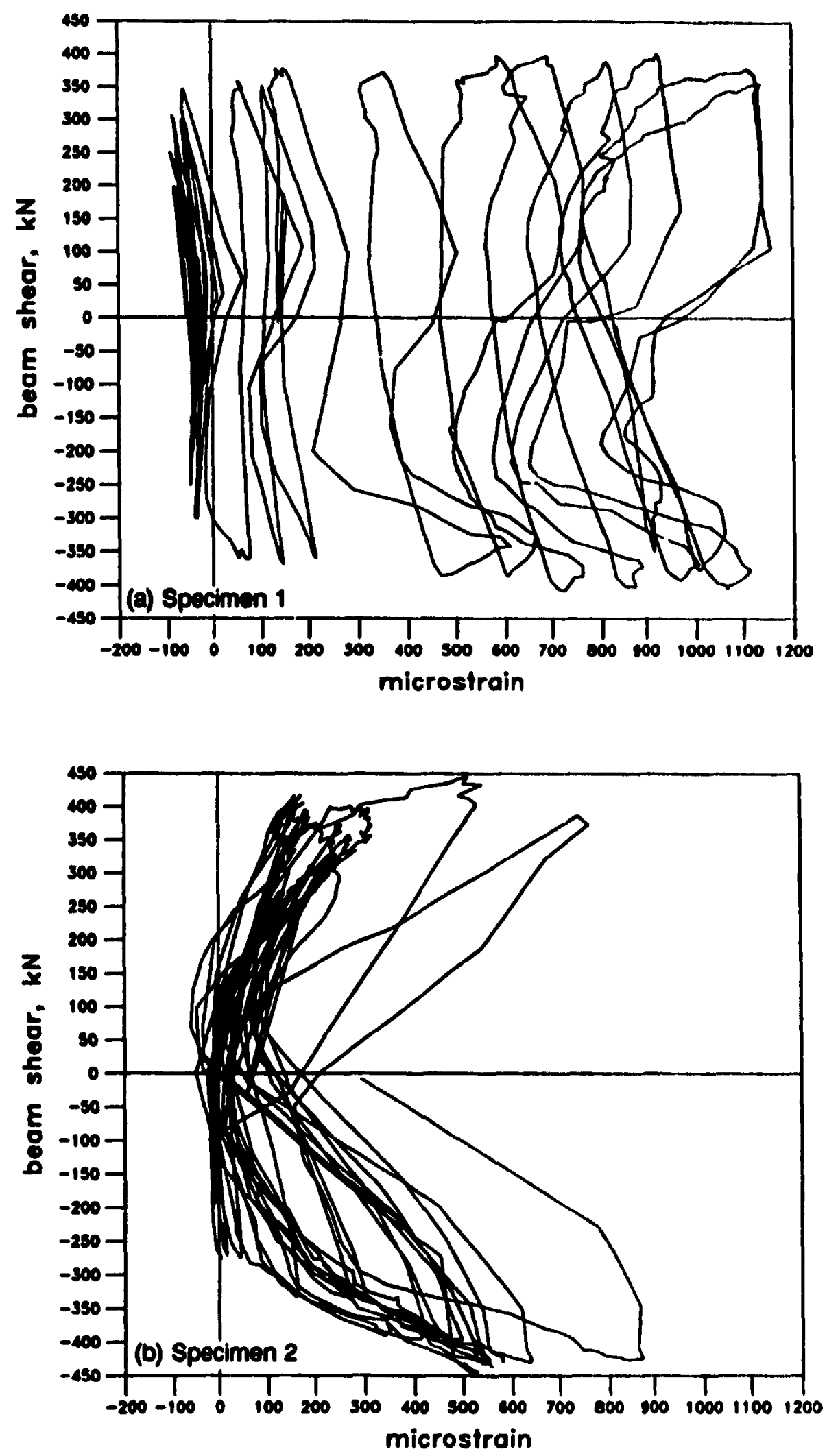

Flgure 6.7 Strains in the longitudinal reinforcing bers at the inside lace of the east wall 

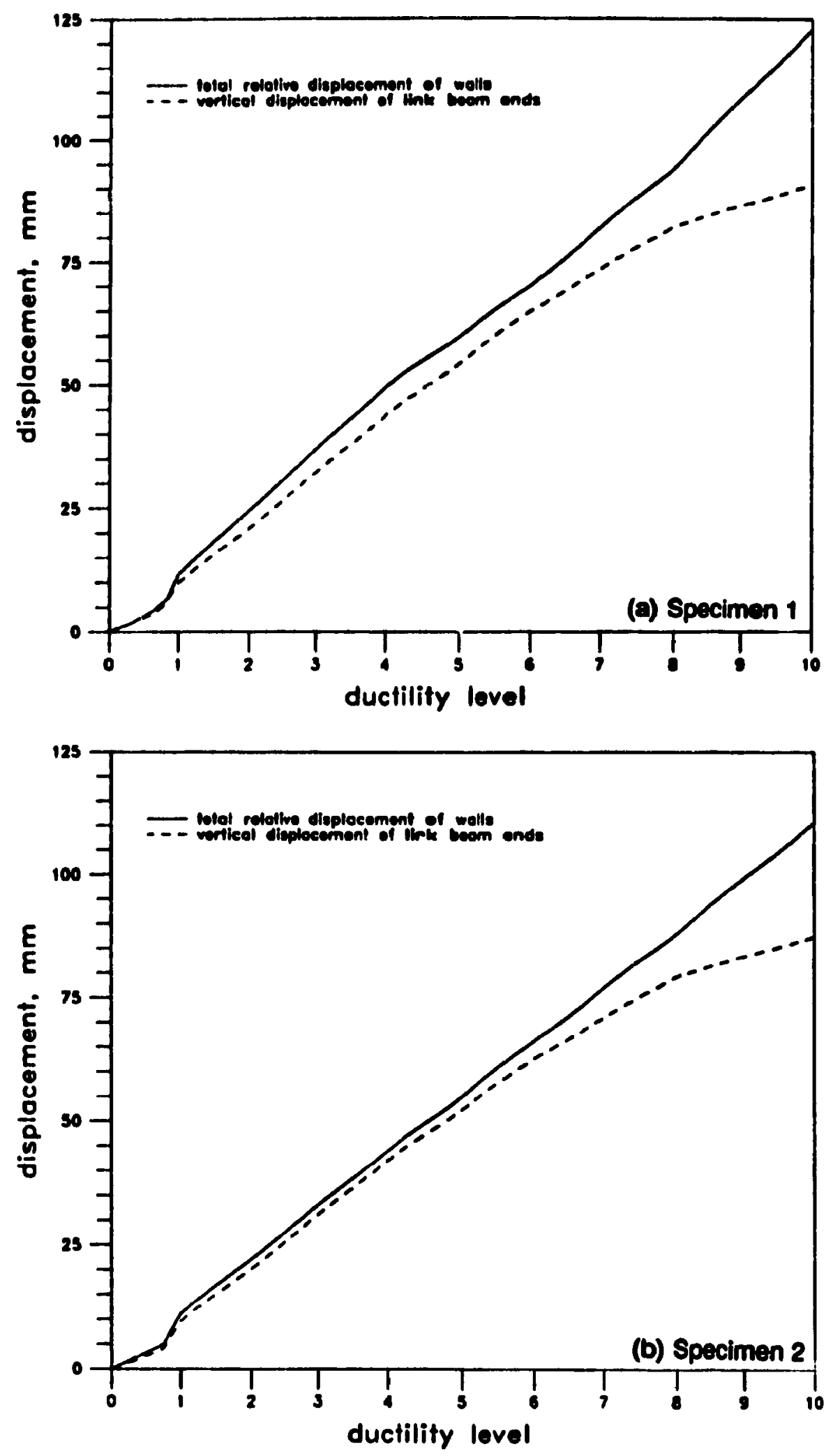

Figure 6.8 Contribution of the displacenents of the link beams to the total relative displacements of the Specimens 
of $85_{y}$, the link beam contributes aboun $92 \%$ of the totel diaplacement. The remaining $8 \%$ is a reault mainly of the inclactic deformations in the embedment. The improved embedment detailing of Specimen 2 reduces this contribution to about 3\% of the total displacement.

The increased diaplacement comtribution due to the inelastic response of the embedment and embedded region above a ductility lovel of about 88, is apparent for both specimens (seo Fig. 6.8). It should be noted, however, that oven at ductily lovels of 108, the link bean continues to represent more than $80 \%$ of the totel diaplacement response. 


\section{Chapter 7 \\ Assessment of Performance of Steel Unk Beams Coupling Reinforced Concrete Walls}

In order to assess the performance of steel link beans coupling reinforced concrete walls, the responses of Specimens 1 and 2 will be compared to the responses of common types of coupling beams tested by others.

\subsection{Comparisons with Roinforced Conerete Coupling Boame}

A discussion of both traditionally reinforced and diegonally reinforced concrete coupling beams is given in Section 1.3. For ductile systems, traditionally reinforced coupling beams, containing longitudinal teel and closed hoops, are only permmed if the shear bs low and $I$ the span-to-depth ratio is reiatively large. Diagonally reinforced coupling beams are required if the shear is high due to their excellent ductility and eneroy absorbing capebility. The diagonal reinforcement is not practical II the span-10-depth ratio is greater than about 2.

Specimens 1 and 2 were constructed and tested to investigate the feasiblity of using steel link beams in reinforced concrete coupled wall systems. These specimens had spantlo-depth ratios of 3.4, signiticantly larger than the practical limit for diagonally reinforced coupling beams.

Two of the specimens fested by Shiu of al. (1978) are representative of the response of traditionally reinforced and diagonally reinforced concrete coupling beams having a span-to-depth ratio of 2.5. If the prototype structure considered in this research programme (see Chaptor 2) had reinforced concrete coupling beams, these beams would have had a span-to-depth ratio of about 2.5. The mysteretic responses of the reinforced concrete coupling beams, tested by Shiu et al. are shown in Fig 1.4.

Figure 7.1 shows the equivalent elastic damping coefficient, $\beta$, for Specimens 1 and 2 and for those tested by Shiu. Both steel link beam specimens exhibited greater energy absorption 
then the disgonely reintorced concrete momber and far greater energy cbocption then the traditionaly reinforced concrete member. Spocimen 2 exhibined the largeat levels of mysteretic damping, whth the lasst amount of decay with cycling.

\subsection{Comparisons with Steel Lnk Beams in Eccontrically Braced Frames}

The response of a representetive steel link beam in an eccentrically breced frame (EBF) was chosen from the work of Engehnerd and Popov (1989). The link beam chosen had similex

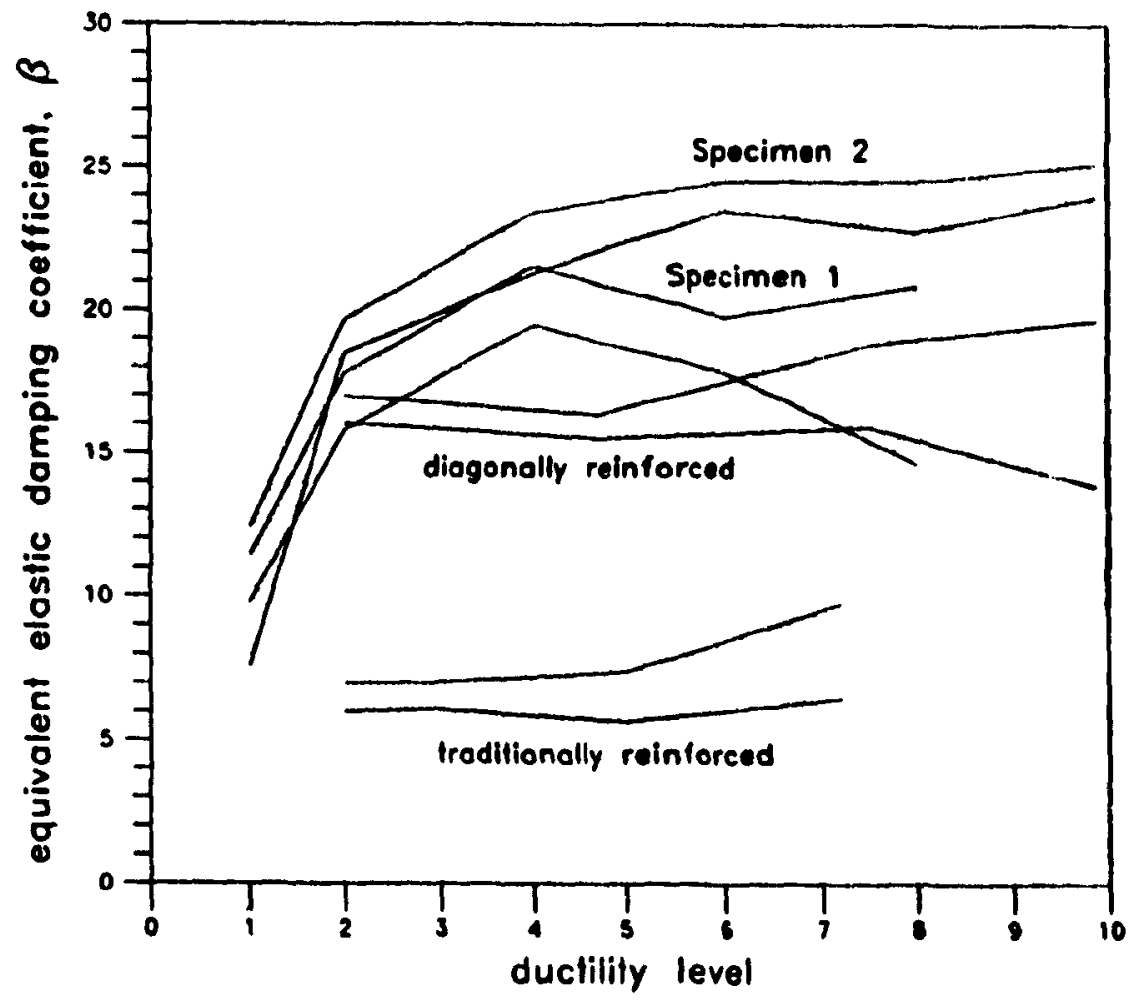

Figure 7.1 Equivalem elastic damping coeficients for Specimens 1 and 2 and reinforced concrete coupling beams tested by Shiu et al. (1978)

dimensions to those of Specimens 1 and 2 and a similar span-to-depth ratio (3.7 veraus 3.4).

Figure 7.2 shows the excellent !ysteretic behaviour of the steel link bean in en EBF, tested by Engelharct and Popov. The ductilities achieved in Specimens 1 and 2 are comparable to those achieved by well-detailed link beams in EBFs. Figure 7.3 shows the equivalem damping coefficient, $\beta$, determined from this hysteretic response and those of Specimens 1 and 2. The 


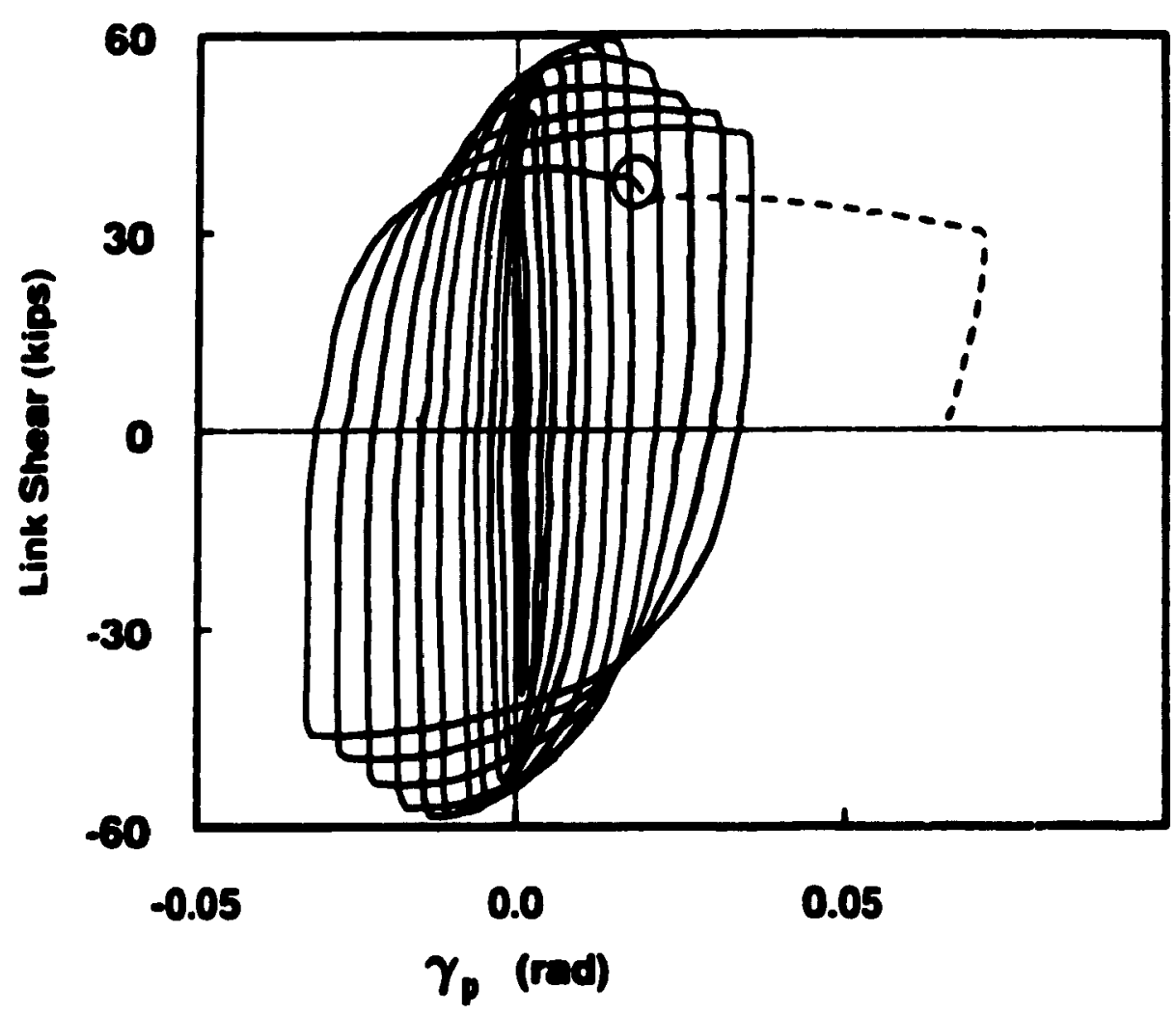

Floure 7.2 Shear versus link beam rotation in an cccentrically braced freme teated by Engetharct and Popov (1989)

tests performed by Engellharct and Popor had only one cycle at each load level and no signlificant decay occurred between the positive and negative half cycles at each displacememt lovel.

H can be soen from Fig. 7.3 that the equivalent elastic damping coefficion for Specimen 2 is comparable to that of the link beam in an EBF, and above that exhibliod by Specimen 1. These comparisons indicate that the refir uments to the deaign of the embedment, in Specimen 2, have been sufficient to koep the embedded $n$ roel member and the embedment region eleatic. The behaviour of Specimen 2 demonstrates the ability of steel link beams coupling reinforced concrete walls 10 provide energy absorption levels and ductilites similar to those provided by ateel link beams in eccentrically braced frames. 


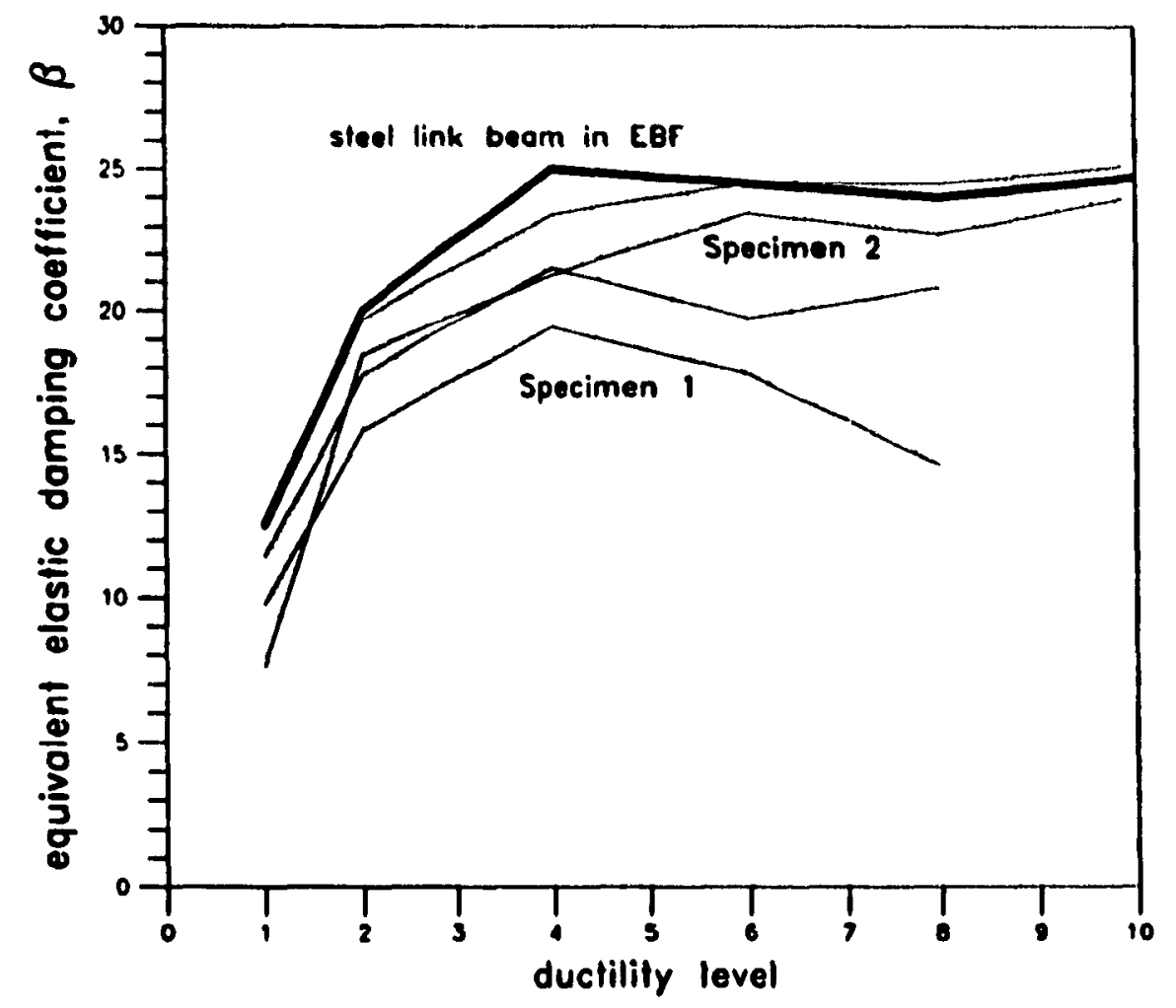

Figure 7.3 Equivalent deastic damping coefilicients for Specimens 1 and 2 and a steal link beam in an eccentrically braced frame tested by Engetharch and Popov (1989) 


\section{Chapter 8 \\ Conclusions and Deolign Recommendations}

In recent years, researchers have investigeted novel approsches for improving the ductility and energy absorption of reinforced concrete coupling beams in ductila fiexural wall systems. For span-10-depth ratios loss then about 2, specielly doteiled diagonal reinforcement (0.9., Peulay and Binney, 1974) has been shown to significantly improve the reversed cyclic loeding reaponse. The objective of this research programme is to investigate the feadbiliny of uaing structural ateel members, having their ends embedded in the wells, 10 replace reinforced concrete coupling beams. Two full-scale, test specimens were designed and tested, in reversed cyclic loading, in order to investigate the response of this new type of conetruction.

The results of this experimental programme heve shown that it is possible to achieve excellem ductilty and eneroy absorption cherecteristlos by carefully designing and detailing the steel link beams and the reinforced concrete embedment regions.

For link beams having small to medium span-to-depth ratios, excellent response, similar to that exhibited by link beams in eccentrically braced frames can be achieved if the following design and detailing requiremems are met:

i. The clear span of the link beam is designed and detailed to remain elastlc in fiexure while attaining tis uttimate capachy in shear according to plawtic deaign requirements.

ii. The web in the clear apan is dotalled auch thu $\mathrm{n}$ can develop large shear deformations beyond ylelding. As such, the wob is chosen to conform with the requirements for a Class 1 section and is adequately stifiened to prevent web and hange instabilities.

iii. In calculating the effective clear span for design purposes, the efiect of the spalling of the cover concrete at the inside face of the wall is taken into account.

iv. Additional stiffeners are provided inside the embedment region, in the region of expected cover spallir : 
Alhough good link bean response wes obtained using these dedion criteria, h was found that oven greater ductilitios and energy abeorption were attained $x$ the wob of the link beam in the embedment region was stengthened in such a way as to asaure that the embedded region of the link bean remained clastic in shoer and froxure while tho link baen clear span atteined hs ultimate shour cespacily.

In order to ensure thet the link beem may perform in the deaired ductile manner, the reinforced concrete embedinent region muet be dexigned and detelled in the following menner:

i. The embedment muat be dealoned for a shear and moment correaponding to the development of the full cepachy of the link bean.

ii. A reduced embedment length must be considered in order to accoun for the eflects of the cover apaling a the inside faces of the walls. This reduction in embedment should correspond to the increased clear epen length used to determine the capacity of the link bean.

iii. Vertical reinforcing bers, placed neer the inside fece of the wcils, muat be sutilicient to provids adsquate control of the crecking along the link bean fienge-concrete interface.

It is important to note that the fiexural walls themectwes muat bo deaigned to reaiat the probable reatuences of the link beams. The design crtieria proposed should be considered in addition to the ductile design and deteiling of the individual weils comprising the syatem.

The use of prefabricated steel link beams embedded in reinforced concrete walls provides an excellent level of quality control for these critical structurel elements. Furthermore, the use of embedded steel link beams greatly simplifies the formwork requirements for coupled walls and requires a significently leas complex erection procedure then tradivioncly or diagonally reinforced concrete coupling beams.

It is evident from th's preliminery research programme that the use of steel link beams in reinforced concrete coupled well systems is a feasible enemative to traditionally or diagonally reinforced concrete coupling beams. The superior performance of this novel structural system is well suited for atuctures designed for large levels of ductility. The relative simplicity of design and erection, however, make this type of system feasible for any coupled wall system.

\subsection{Areas for Further Investigation}

The encouraging results of this preliminary study suggest a number of possibilities for future investigations of steel link beams in reinforced concrete coupled wall systems. These include: 


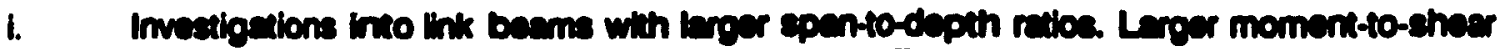
retios would be present in longer beame, the clibct of these increased ratios on the decion of the fink basme neads to bo inveripenced.

ii. Methods of providing mechanical connections of the link bean to the embedment concrete should be imvestigned. Thees would inctuds 'dreg bers' mounted to the embedded portion of the link been or poctitwe connection of the link boem to the vertical reinforcement as the inside face of the well.

iil. A simpler epprosech for strengthening the wob in the embedinemt region would be to provide a doubler plate, welded all around and phug welded to the original wob (deaigned for the clear span). This method of stiliening the embedded wob is simpler and more practicel than the butt-welded composite mob uned in Specinnen 2 . The efiect of the eccentricily introduced by the docibler plete in the embedment would have to be investigated.

w. Tests need to be performed on steel link baems having lower lovels of ductility (llexural hinging modes) in order to provide design and deteiling guidence for structures designed with lower $R$ velues.

v. The degree of lateral support supplied by the well embedment to the link beem should be inveetigated and compered to the recent leteral load recommendetions proposed by Engehthard and Popov (1989). Furthermore the degree of laxerel support, 1 any, supplied by the presence of a froor slab should be inveatigated.

vi. The interaction of locallised embedment forces, together with the level of axial load in the walls should be investigated.

vii. The possibility of uing externally spplied stuctural stoel plates as a retrofit measure for existing reinforced concrete coupling beams should be investigated. Such an investigation would examine the response of a reinforced concrete coupling bean proviousty subjected to a number of load cycles at hs senvice load lovel and then retrolitted with an external steel plate. 


\section{Reforences}

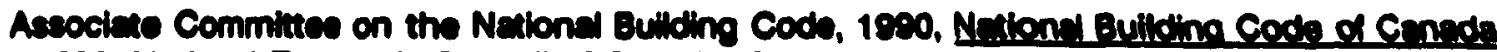
1992. Netional Reaserch Council of Censeds, Onewre, Ont.

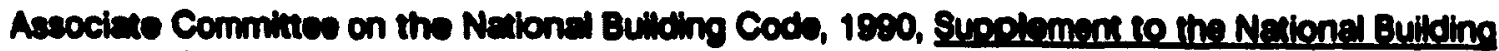

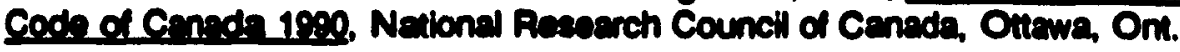

Cenadian Inatitute of Steel Construction (CISC), 1885, Hendpook of Steal Construction, CISC, Willowdale, Ont.

Cansdian Portand Cement Association (CPCA), 1986, Concrese Desion Handbook, CPCA, Ottenva, Ont.

Canadlan Preatreased Concrete Inatitute (CPC), 1897, Metric Desion Menuey, CPCl, Ottawa, Ont.

Prestreased Concrete Institute (PC), 1985, PCI Desion Henoboek, PCI, Chicago, III.

SEAOC, 1988, Recommended Leterel Foras Requirements, Selemology Committee, Structural Engineers Association of Calliomia (SEAOC).

Berg, V.B. and Stratta, J.L., 1964, Anchorme and the Alagka Earthounke of March 27, 1964, American Iron and Steel Inathute, Now York, 63 pp.

Bertero, V.V. and Popov, E.P., 1975, Hysteretic behaviour of reinforced concrete flexural members with special wob reinforcemont, Proceselinos of U.S. Netlonal Conference on Earthquake Enoinearing, Ann Abor, Jume 1975, pp 316-328.

Engelharch, M.D. and Popov, E.P., 1989, Beheviour of Lona Links in Eccentrically Braced Frames, Earthquake Engineering Research Center, Berkeley, Report NO. UCB/EERC;-89/01, 406 pp.

Fioraco, A.E. and Corley, W.G., 1977, Laboratory tests of oanthquake resistant structural wall systems and elements, Workshos on Exthquake Rosident Reinforced Concrete Building Construction, vol. III, University of Calfornia, Berkeley, Juby 1977, pp 1397-1402.

Harries, KA. Cook, W.D., Redwood, R.G. and Mitchell, D., 1992, Concrete walls coupled by ductile steol link beams, Procesedinos of Tenth World Eerthouake Enoingering Conference, Madrid, July, 1992.

Hewkins, N., Mitchell, D. and Hanna, S., 1975, The effects of shear reinforcement on the reversed cyclle loading bohoviour of flat plate structures, Canadian Journal of Chill Enoinegring, Vol. 2. No. 4, Decomber 1975, pp 572-s82.

Kasai, K and Popov, E.P., 1986, A Study of Setimically Ropletent Eccentrically Braced Frameg, Earthquake Engineering Research Cemer, Berkoley, Report NO. UCB/EERC-86/01, 215 pp.

MacLeod, I.A., 1968, Leferal Stifness of Shegr Welle with Openinos in Tall Buildings, Pergamon Press, Oxford pp 142.162. 


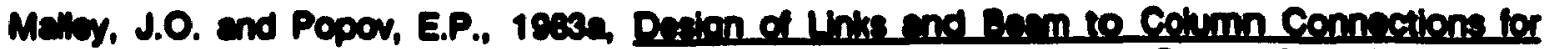

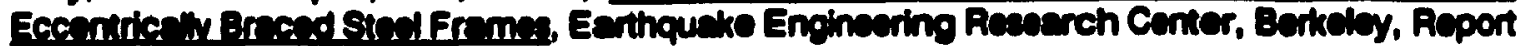
NO. UCBVEERC-83/03, 62 pp.

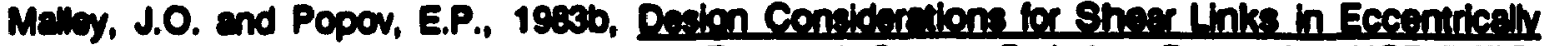
Breced Frrmes, Eerthquake Engineering Recearch Center, Berkeley, Report No. UCB/EEAC. 83/24, 117 pp.

Marcakts, C. end Mikchell, D., 1980, Precast concreve connections with embedded stoel members, PCl Joun:y, Vol. 25, No. 4, JuylAuguet 1880, pp 88-116.

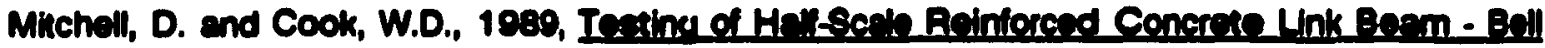

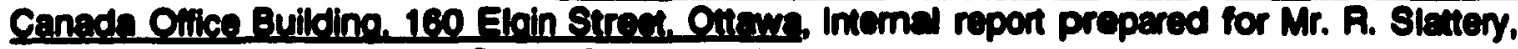
Houser, Henry, Louden and Syron, Toronto. 19pp.

Paparoni, M., 1972, Model studies of coupling boams, Procaedinos of the IntemetionalConference on Tall Concrese end Masonn Buildinon, Augua, 1972, Vol. 3, pp 671-681.

Park, R. and Paulay, T., 1975, Reinioxead Concrete Sinutures, John Wiley and Sons, Now York. (Chapter 12 . Shear Walts of Multitory Building.)

Pauley, T., 1960, The Coupline of horer walle, Volumes 1 and 2, (doctord theals, Untverstly of Canterbury, New Zesland). 432 pp.

Paulay, T., 1971, Simulated seismic loading of spandret beams, Joumal of Structurel Division, ASCE, Vol 97, ST9, September, 1971, pp 2407-2419.

Paulay, T. and Binney, J.R., 1974, Diagonaly reinforced coupling beams of shoar walls, Shear in Reinforced Concrete, Special Publication No. SP-42, Americen Concrete Insthure, Detroit. pp 579.598.

Paulay, T., 1976, Ductility of reinforced concrete shoanwalls for seismic areas, Reinforeed Concrete Structures in Seismic Zones, Special Publication No. SP.53, American Concrete Institute, Detroit. pp 127-147.

Paulay, T., 1986, The design of ductile reinforced concrete structural walls for earthquake resistance, Eanhouake Spectra, Vol. 2, No. 4, 1886, pp 783-823.

Reoder, C.W. and Popov, E.P., 1978, Eccentrically braced stoel frames for earthquakes, Joumal d the Stauctural Division, ASCE, Vol. 104, No. ST3, March 1978, pp $391-411$.

Rosman, R., 1964, Approximate analysis of shoar walls subject to lateral loads, American Concrete Institute Joumal, Vol. 61, No. 6, June 1984, pp 717-732.

Santhakumar, A.R., 1974, Ductiliv of coupled shear walls, (doctoral thesis, University of Canterbury, New Zealand). 385 pp.

Schwaighofer, J. and Microys, H.F., 1970, Anaksis of Shear Wall Sinuctures using Standard Computer Proorams 
Shiu, KN., Bamby, C.B., Fiorato, A.E. and Corky, W.C., 1978, Reversed load reats of reinforced

tio

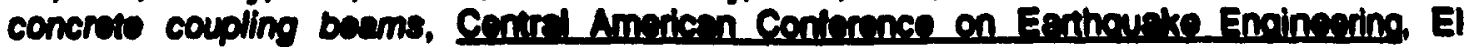
Selvedor, January 1978, pp 230249.

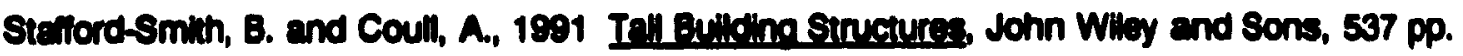

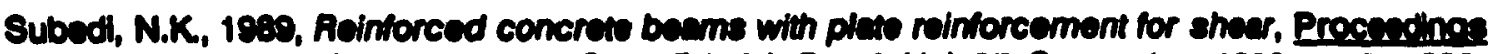

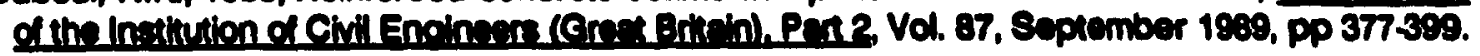

84 


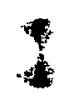

Appendix A

\section{Dealgn and Analyels of Teet Specimens}


Appendix A.1 - Dealgn of Steel Link Beam with Speelfied Matorial Propertice Tribl ecetion:

Flange: $134 \times 18 \mathrm{~mm}$

Clawes numbers refer to CANYCSA s16.1-M90.

Web: $5 \mathrm{~mm}$ thick

Overeil Height: $350 \mathrm{~mm}$

$F_{y}=300 \mathrm{MPa}$

Veriliedtien: Class of Section

$$
\begin{aligned}
& \frac{b}{2 i}=\frac{184}{30}=3.72<\frac{145}{\sqrt{F_{y}}}=8.37 \text { Chase } 1 \\
& \frac{n}{w}=\frac{(850-80)}{5}=62.8<\frac{1100}{\sqrt{F_{y}}}=08.5 \text { Clase } 1
\end{aligned}
$$

Bending rochenes:

$$
\begin{aligned}
M_{r} & =\left(0.28(5)\left(819^{2}+134(10)(600-19)\right) 0.3 \times 10^{-0}\right. \\
& =(12 \times 245+600704) 0.3 \times 10^{-5} \\
& =272 \mathrm{kNm}
\end{aligned}
$$

but the web should be lonored beceuse in is yielding in showr:

$$
\begin{aligned}
& \therefore M_{f}=\text { (Pootrea) } 0.3 \times 10^{-9} \\
& \text { - } 240.2 \mathrm{kANm}
\end{aligned}
$$

Shoar realeteneo:

$$
\begin{aligned}
& v_{p}=0.65 \mathrm{~A}_{y} \\
& =0.60(600)(0)(0.300) \\
& \text { - 200kN }
\end{aligned}
$$

including the efrect of strain hardening:

$$
\begin{aligned}
& V_{p}=0.70 A_{F} F_{y} \\
& \text { - 0.70psó)(0)(0.800) } \\
& \text { - sask }
\end{aligned}
$$

ascuming a clear epan of $1200 \mathrm{~mm}$ :

\begin{tabular}{|c|c|c|c|}
\hline & $V(\mathrm{~N})$ & $M(\mathrm{~N} \cdot \mathrm{m})$ & $M_{\mathrm{r}}(\mathrm{NN} \cdot \mathrm{m})$ \\
\hline Thoorctical shoer yind loend & 200 & 173 & 240 \\
\hline Probeble maximum shoer load & 308 & 221 & 240 \\
\hline
\end{tabular}


Wob etilieners:

full depth: at ends, $1=10 \mathrm{~mm}$

dietence from ends: $600 \mathrm{~mm}$

Intermediete:

spaning $\leq 39 w-0.2 d$

- $30(0)-0.2(650)$

SD8(a)

$-120 \mathrm{~mm}$

all one sided atliener platea:

$$
\text { wans }>\frac{184}{2}-5=02 \mathrm{~mm}, .2 x 65 \times 10 \mathrm{~mm}
$$

500

weld to web: wold must trenster:

$$
A_{F_{y}}=195 \mathrm{kN}
$$

8010

use $5 \mathrm{~mm}$ wold on one sids:

$$
V_{p}=0.708(202)-247 \mathrm{kN}>185 \mathrm{kN} \ldots \text { OK }
$$

weld to flenges: capiacity of each end:

$$
0.25 A_{F}=49 \mathrm{kN}
$$

8010

length of $5 \mathrm{~mm}$ wold required:

$$
\operatorname{lng}>\frac{40}{0.735}=84 \mathrm{~mm}
$$

uee a $5 \mathrm{~mm}$ wald full length on one side.

Ends:

$$
\frac{h_{1}}{f_{0}}=\frac{314}{5}=02.8<\frac{1100}{\sqrt{F_{y}}}=0.6
$$

therefore stilienars are not required.

Wob to fiones welde:

must doviblop yiald atreas of wob:

$$
00.67 F_{y}=2 y_{1} 1 \mathrm{kMmm}
$$

$2.5 \mathrm{~mm}$ molds have cepecty:

$$
2(0)(163)\left(10^{-9}\right)=1.63 \mathrm{kA} / \mathrm{mm} . . . \text { ox }
$$


Clause 27.2.2.1.(b) requires:

$$
L_{-}=\frac{80 r_{y}}{\sqrt{F_{y}}}=\frac{900 \times 39.09}{\sqrt{10}}=1922.8 \mathrm{~mm}>1200 \mathrm{~mm} . . . \text { or }
$$

Wob in embadded region of spectmen 2: required to remein elactic

Consider thet the moment cepecity is resched:

$$
V_{p}=\frac{M_{r}}{\frac{1}{2}}=\frac{2772}{\frac{1800}{2}}=401.7 \mathrm{kN}
$$

solving for the required wob thickness:

$$
t_{w}=\frac{V_{p}}{0.65 \mathrm{~F}_{y}}=\frac{401.6}{0.65 \times 350 \times 0.500}=7.00 \mathrm{~mm}
$$

choose an $8 \mathrm{~mm}$ web size inaida the pint region.

Clearspan web to joint wob weld: consider a full depth double bevel groove weld.

The joint resistence is the smellor of:

$$
\begin{aligned}
& V_{r}=0.07 \$ F A_{m}-0.67 \times 0.9 \times 0.000 \times 830 \times 6=310 \mathrm{kN} \text { or } \\
& v_{p}=0.07 Q_{1} A_{1}=0.07 \times 0.07 \times 0.400 \times 310 \times 5=384 k N
\end{aligned}
$$

therefore, a full depth double bevel groove weld, butt wilding the $5 \mathrm{~mm}$ and $8 \mathrm{~mm}$ web pletes will be sumicient 10 camy the sheer of $289 \mathrm{kN}$. 
Speclimen 1

$$
\begin{aligned}
& F_{y} \text { of thange }=372 \mathrm{MPa} \\
& F_{\text {, of }} \text { wob = } 320 \mathrm{MPa} \\
& d=350 \mathrm{~mm} \\
& b=135 \mathrm{~mm} \\
& h=19.7 \mathrm{~mm} \\
& \mathrm{t}=5.0 \mathrm{~mm}
\end{aligned}
$$

Floxural realotanee (excluding web)

$$
\left.M_{r}=\left(b t_{f} d-t_{f}\right)\right) F_{y}=136 \times 10.7 \times(360-19.7) \times 0.372 \times 10^{-5}=326.7 \mathrm{kNm}
$$

considering the nominal value of $F_{y}=300 \mathrm{MPa}$ :

$$
M_{r}=\left(b t_{f}\left(d-t_{f}\right)\right) F_{m m}=135 \times 10.7 \times(360-19.7) \times 0.300 \times 10^{-9}=203.4 \mathrm{kNm}
$$

Shaer redietance

$$
V_{r}=0.68 A_{w} F_{y}=0.65 \times 380 \times 5 \times 0.320=300 \mathrm{kN}
$$

Shear reabtanse Including etraln hardening elloct

$$
V_{f}=0.7 A_{w} F_{y}=0.7 \times 350 \times 5 \times 0.320=302 \mathrm{kN}
$$

\begin{tabular}{|l|c|c|c|}
\cline { 2 - 4 } \multicolumn{1}{c|}{} & $V(\mathrm{NN})$ & $M(\mathrm{NN} \cdot \mathrm{m})$ & $M_{1}(\mathrm{NN} \cdot \mathrm{m})$ \\
\hline Shaer Yold & 303 & 185 & 263 \\
\hline Shoar Maximum & 392 & 235 & 263 \\
\hline
\end{tabular}


Specimen 2

$$
\begin{aligned}
& F_{y} \text { of nange }=295 \mathrm{MPa} \\
& F_{y} \text { of web }=3.09 \mathrm{MPa} \\
& F_{y} \text { of joint wed }=276 \mathrm{MPa} \\
& d=345 \mathrm{~mm} \\
& b=135 \mathrm{~mm} \\
& 4=19.2 \mathrm{~mm} \\
& 4=4.7 \mathrm{~mm} \\
& \mathrm{~L}_{\mathrm{m}}=8.1 \mathrm{~mm}
\end{aligned}
$$

Floxural realetance (exchuding web)

$$
M_{r}=\left(b f_{f}\left(d-r_{f}\right)\right) F_{y}=135 \times 19.2 \times(845-19.2) \times 0.295 \times 10^{-9}=249.1 \mathrm{kNm}
$$

Shoar rechetence

$$
V_{p}=0.65 A_{w} F_{y}=0.65 \times 345 \times 4.7 \times 0.300=276 \mathrm{kN}
$$

Shear reabeance Inchuding streln hardening efiect

$$
V_{r}=0.7 A_{w} F_{y}=0.7 \times 346 \times 4.7 \times 0.300=300 \mathrm{kN}
$$

Shoar realetence of embedded link boem

$$
V_{p}=0.65 A_{w} F_{y}=0.65 \times 245 \times 8 \times 0.276=419 \mathrm{kN}
$$

\begin{tabular}{|l|c|c|c|}
\cline { 2 - 4 } \multicolumn{1}{c|}{} & $V(\mathrm{kN})$ & $M(\mathrm{kN} \cdot \mathrm{m})$ & $M_{1}(\mathrm{kN} \cdot \mathrm{m})$ \\
\hline Web Shoar Yiald & 275 & 165 & 249 \\
\hline Web Shear Unimate & 360 & 210 & 249 \\
\hline Joim Shrear Yiold & 410 & 251 & 249 \\
\hline
\end{tabular}




\section{Appendix A.3 - Decign of Rolnforced Conerets Embedment Raglons}

Spoelmen 1

$$
\begin{aligned}
& I=600 \mathrm{~mm} \\
& b=600 \mathrm{~mm} \\
& \text { bearing widh }=135 \mathrm{~mm} \\
& \text { centre to centre of ties }=208 \mathrm{~mm} \\
& f_{6}^{\prime}=26 \mathrm{MPa}
\end{aligned}
$$

Embedmemt eapeclify: (according to Mirchell and Marcakts, 1980)

$$
\text { Lswerm }=0=1+\frac{1}{2}=000+\frac{000}{2}=000 \mathrm{~mm}
$$

Note that this eccentricity does not account for the effects of cover spaming

Capaciny of concreie embedment region:

$$
V_{0}=\frac{0.85 r_{0} y_{0}}{1+3.6 \frac{0}{6}}=\frac{0.85 \times 28 \times 200 \times 000}{1+3.6 \times \frac{000}{600}}-400 \mathrm{kN}
$$

Required Cepachy:

Expected shear yleld $=308 \mathrm{kN} \ldots \ldots \ldots \ldots \ldots \ldots \ldots$ OK Expected maximum shear $=392 \mathrm{kN}$ OK 
Specimen 2

$$
\begin{aligned}
& l=840 \mathrm{~mm} \\
& l_{c}=580 \mathrm{~mm} \\
& c=40 \mathrm{~mm} \\
& \text { bearing wioth }=135 \mathrm{~mm} \\
& \text { centre } 10 \text { centre of tise = } 208 \mathrm{~mm} \\
& l_{c}^{\prime}=43 \mathrm{MPa}
\end{aligned}
$$

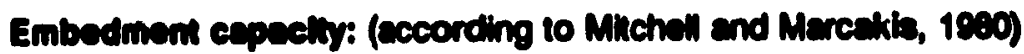

$$
\text { Lam am }=0-1+\frac{1}{2}+c=800+\frac{800}{2}+40=920 \mathrm{~mm}
$$

Note that this eccenticiny does sccount for the eflects of cover epsining

Cepecily of concrete embectment region:

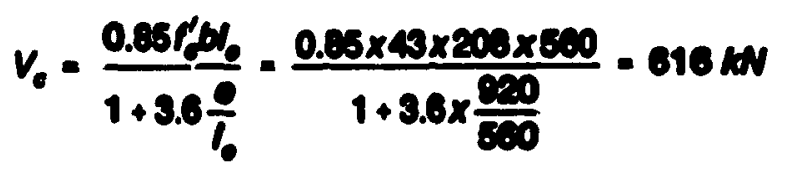

Required Cepeciny:

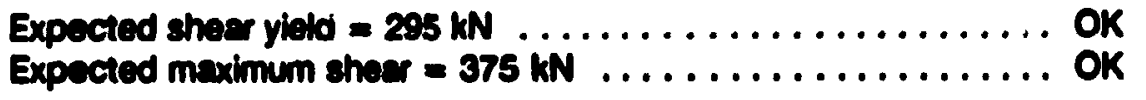


j

Appendix $B$

\section{Summary of Loads and Defiections at the Peak Load Stages}


Spoelmon 1

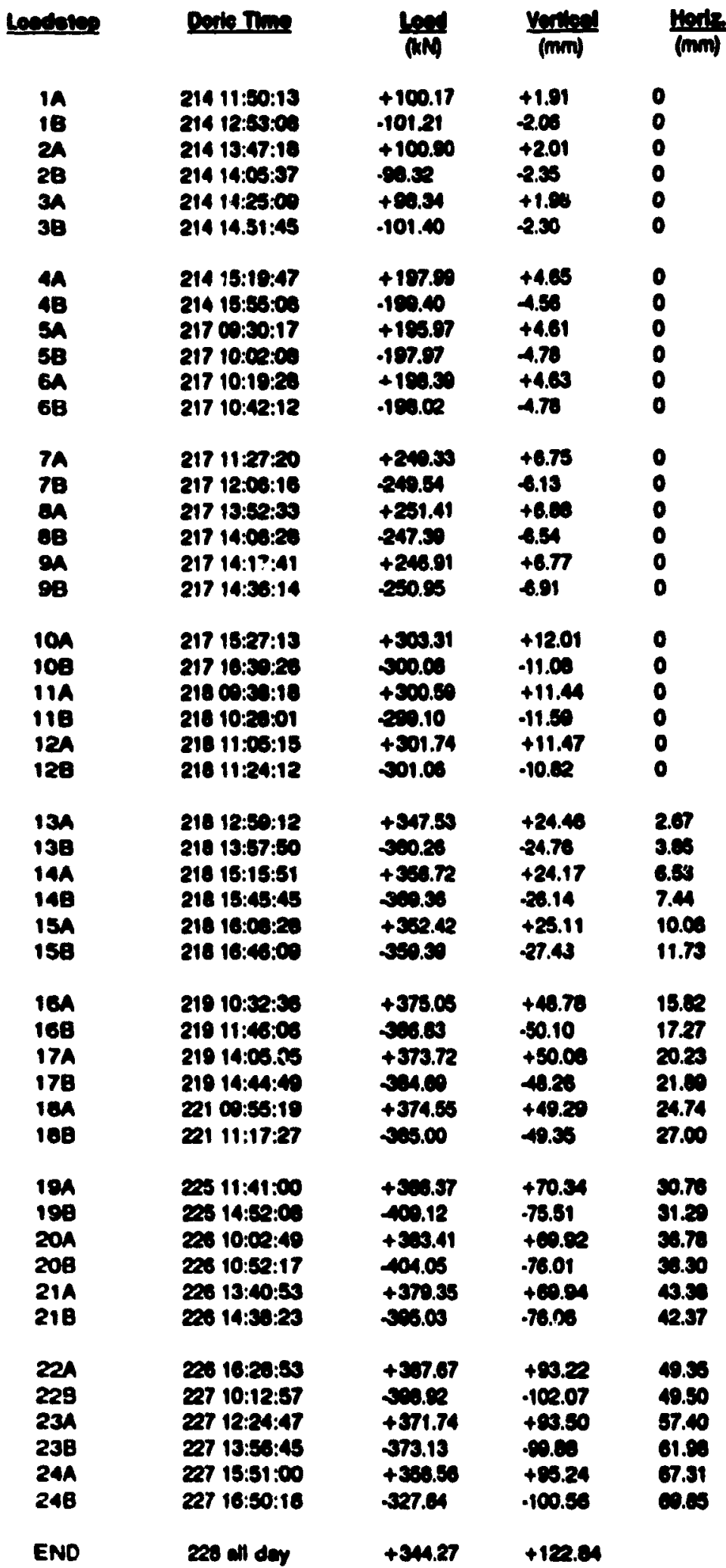

Lision

fint erech it bean top finge

fint erect at beam betiom flanges

firt beed ylekting of bean wob

generel yield in beasn wob; firct epalling

frent ecwer cempining erached

erushing a beeth flenges

eruching at beth franges

enching mere severe

firet wited oruck $600 \mathrm{~mm}$ from fees yild and bueking of wob silimenes

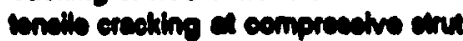
incill herizental clempes

notablo bendivg in end web ntiflenere

hont eover epalnd on

elde cover coaliting; winting of bean hrituer fromt cover sparing

bes of contined conerew behind epeling elds cocining rectreined by vertied efemp no conerew cround finse rebarn; fint yibld of nobare 
5

\section{Spacimon 2}

\begin{tabular}{|c|c|c|c|c|c|}
\hline $9 x+12 x$ & Date Inin & $\frac{\operatorname{lex} 1}{(\mathrm{~N})}$ & $\frac{\text { Yonl:al }}{(m m)}$ & $\frac{\text { And: }}{(\mathrm{mm})}$ & nist \\
\hline $\begin{array}{l}1 A \\
18 \\
2 A \\
2 A \\
3 A \\
3 A\end{array}$ & $\begin{array}{l}310 \text { 17:07:52 } \\
310 \text { 17:50:20 } \\
310 \text { 18:04:41 } \\
310 \text { 18:19:22 } \\
310 \text { 18:24:24 } \\
310 \text { 10:33:34 }\end{array}$ & $\begin{array}{l}+100.12 \\
+\infty .18 \\
+\infty 9.60 \\
-101.32 \\
+\infty 0.85 \\
+\infty 3.61\end{array}$ & $\begin{array}{l}+2.30 \\
-2.30 \\
+2.00 \\
-2.30 \\
+2.50 \\
2.30\end{array}$ & $\begin{array}{l}0 \\
0 \\
0 \\
0 \\
0 \\
0\end{array}$ & \\
\hline $\begin{array}{l}4 A \\
48 \\
5 A \\
68 \\
6 A \\
6 B\end{array}$ & $\begin{array}{l}311 \text { 09:44:19 } \\
311 \text { 11:12:17 } \\
31111: 20: 82 \\
31111: 33: 83 \\
31111: 44: 47 \\
311 \text { 13:22:82 }\end{array}$ & $\begin{array}{l}+190.93 \\
-194.22 \\
+199.01 \\
-190.21 \\
+192.16 \\
-196.40\end{array}$ & $\begin{array}{l}+4.94 \\
4.50 \\
+4.91 \\
-8.20 \\
+4.60 \\
5.33\end{array}$ & $\begin{array}{l}0 \\
0 \\
0 \\
0 \\
0 \\
0\end{array}$ & 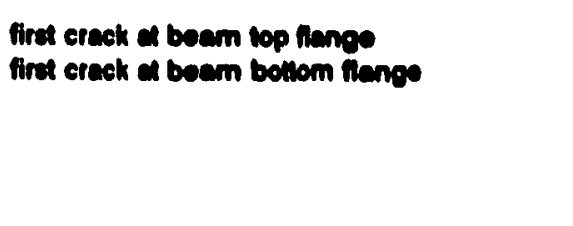 \\
\hline $\begin{array}{l}7 A \\
78 \\
8 A \\
88 \\
8 A \\
8 B\end{array}$ & $\begin{array}{l}311 \text { 14:20:40 } \\
311 \text { 15:30:40 } \\
311 \text { 15:33:37 } \\
311 \text { 16:40:52 } \\
312 \text { 10:10:16 } \\
312 \text { 10:57:42 }\end{array}$ & $\begin{array}{l}+273.84 \\
272.04 \\
+275.40 \\
-273.75 \\
+273.56 \\
-274.02\end{array}$ & $\begin{array}{l}+11.40 \\
-9.16 \\
+10.00 \\
-10.64 \\
+11.00 \\
-\infty .63\end{array}$ & $\begin{array}{l}0 \\
0 \\
0 \\
0 \\
0 \\
0\end{array}$ & $\begin{array}{l}\text { ennerd yiold in bean wob } \\
\text { firet verticel erecking in both walls }\end{array}$ \\
\hline $\begin{array}{l}104 \\
108 \\
114 \\
118 \\
12 A \\
128\end{array}$ & $\begin{array}{l}312 \text { 11:00:01 } \\
312 \text { 12:46:17 } \\
312 \text { 14:10:23 } \\
312 \text { 14:49:13 } \\
312 \text { 19:22:17 } \\
312 \text { 14:09:52 }\end{array}$ & $\begin{array}{l}+311.02 \\
332.00 \\
+324.26 \\
334.63 \\
+305.46 \\
334.07\end{array}$ & $\begin{array}{l}+22.05 \\
-22.24 \\
+21.00 \\
-2.00 \\
+22.48 \\
-20.11\end{array}$ & $\begin{array}{l}\mathbf{0} \\
\mathbf{0} \\
\mathbf{0} \\
\mathbf{0} \\
\mathbf{0} \\
\mathbf{0}\end{array}$ & \\
\hline $\begin{array}{l}13 A \\
138 \\
14 A \\
148 \\
15 A \\
189\end{array}$ & 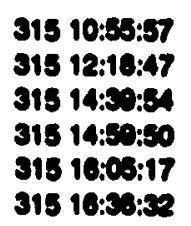 & $\begin{array}{l}+30.40 \\
233.54 \\
+303.18 \\
233.04 \\
+371.49 \\
209.04\end{array}$ & $\begin{array}{l}+44.19 \\
44.58 \\
+43.99 \\
4.18 \\
+44.09 \\
45.43\end{array}$ & $\begin{array}{l}0 \\
3.27 \\
0 \\
4.86 \\
1.06 \\
6.17\end{array}$ & clace formetion of toncion crecks diong ofruts \\
\hline $\begin{array}{l}184 \\
188 \\
17 A \\
178 \\
184 \\
188\end{array}$ & $\begin{array}{l}316 \text { 11:03:30 } \\
316 \text { 12:20:46 } \\
316 \text { 14:80:50 } \\
316 \text { 15:24:30 } \\
31617: 17: 06 \\
316 \text { 17:50:50 }\end{array}$ & $\begin{array}{l}+300.50 \\
420.00 \\
+401.02 \\
420.09 \\
+400.51 \\
427.01\end{array}$ & $\begin{array}{l}+85.97 \\
-85.23 \\
+68.29 \\
-87.07 \\
+68.40 \\
+6.03\end{array}$ & $\begin{array}{l}3.28 \\
0.05 \\
8.08 \\
15.93 \\
13.02 \\
21.07\end{array}$ & 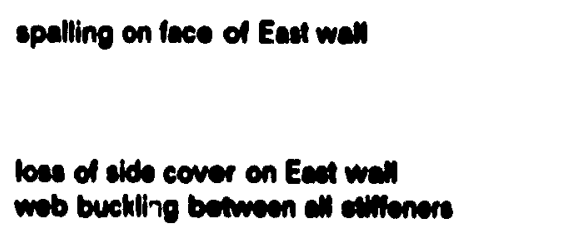 \\
\hline $\begin{array}{l}184 \\
198 \\
204 \\
208 \\
214 \\
218\end{array}$ & $\begin{array}{l}31711: 49: 43 \\
31712: 91: 01 \\
31715: 40: 07 \\
31718: 52: 24 \\
31811: 44: 34 \\
31815: 57: 41\end{array}$ & $\begin{array}{l}+40.01 \\
448.69 \\
+412.13 \\
433.07 \\
+483.41 \\
406.04\end{array}$ & $\begin{array}{l}+\infty .01 \\
-0.34 \\
+\infty 2.01 \\
+0.03 \\
+\infty 8.18 \\
+2.79\end{array}$ & $\begin{array}{l}22.70 \\
33.02 \\
33.02 \\
42.44 \\
45.20 \\
38.52\end{array}$ & $\begin{array}{l}\text { both joint wobe yielding } \\
\text { yielding of wob ctillenen }\end{array}$ \\
\hline $\begin{array}{l}201 \\
220 \\
\text { end }\end{array}$ & $\begin{array}{l}31011: 50: 50 \\
31013: 17: 22 \\
319 \text { 15:44:28 }\end{array}$ & $\begin{array}{r}29.70 \\
424.18 \\
\$ 31.31\end{array}$ & $\begin{array}{l}+110.04 \\
-110.20 \\
-150.20\end{array}$ & $\begin{array}{l}86.03 \\
71.03\end{array}$ & \\
\hline
\end{tabular}

